UNIVERSIDADE DE SÃO PAULO

FACULDADE DE MEDICINA DE RIBEIRÃO PRETO

PROGRAMA DE MESTRADO PROFISSIONAL EM GESTÃo DE ORGANIZAÇÃO DE SAÚDE

\title{
ABSENTEÍSMO POR DOENÇAS EM DOCENTES DO ENSINO FUNDAMENTAL
}

RAQUEL AMÉLIA COSTA

Ribeirão Preto 


\section{Raquel Amélia Costa}

Absenteísmo por doenças em docentes do ensino fundamental

Dissertação apresentada à Faculdade de Medicina de Ribeirão Preto da Universidade de São Paulo para obtenção do título de Mestre em Ciências: Mestrado Profissional em Gestão de Organização de Saúde.

Área de Concentração: Gestão de Organização de Saúde

Orientador: Prof. Dr. Amaury Patrick Gremaud

Ribeirão Preto 
Autorizo a reprodução e divulgação total ou parcial deste trabalho, por qualquer meio convencional ou eletrônico, para fins de estudo e pesquisa, desde que citada a fonte.

Costa, Raquel Amélia Absenteísmo por doenças em docentes do ensino fundamental. Ribeirão Preto, 2017.

80 p.: $30 \mathrm{~cm}$

Dissertação de Mestrado apresentada ao Programa de Mestrado Profissional em Gestão de Organização de Saúde da Faculdade de Medicina de Ribeirão Preto/USP, 2017. Área de Concentração: Gestão de Organização de Saúde.

Orientador: Gremaud, Amaury Patrick

1. Absenteísmo. 2. Saúde Profissional. 3. Educação. 
Nome: COSTA, Raquel Amélia

Título: Absenteísmo por doenças em docentes do ensino fundamental

Dissertação de Mestrado apresentada ao Programa de Mestrado Profissional em Gestão de Organização de Saúde da Faculdade de Medicina de Ribeirão Preto / USP.

Aprovado em:

Banca Examinadora

Prof. Dr.

Instituição:

Julgamento:

Prof. Dr.

Instituição:

Julgamento:

Prof. Dr.

Instituição:

Julgamento:

Prof. Dr.

Instituição:

Julgamento: 


\section{DEDICATÓRIA}

Dedico este trabalho aos meus pais, Airton (in memoriam) e Maria Lúcia, com todo meu amor e gratidão, por tudo que fizeram por min ao longo de minha vida. 


\section{AGRADECIMENTOS}

Ao Professor Doutor Amaury Patrick Gremaud, agradeço, primeiramente, por ter aceitado ser meu orientador e por ter acreditado em mim.

Ao Professor Doutor Altacilio Aparecido Nunes, por valorizar e aceitar a proposta de interfase entre a Educação e a Saúde.

Aos docentes responsáveis pelas disciplinas cursadas durante o mestrado, pela contribuição para a minha pesquisa e para minha formação.

À Secretaria da Educação de Ribeirão Preto, por fornecer as informações fundamentais a minha pesquisa.

Ao Túlio Anselmi Dorigan, pela ajuda fundamental com as planilhas de Excel e pela paciência em responder minhas dúvidas.

Aos funcionários do Programa de Mestrado Profissional, principalmente à secretária Maria Claudia Propheta Alvespela, pela colaboração prestada sempre que solicitada.

À bibliotecária Maria Cristina M. Ferreira, pela orientação com as normas acadêmicas.

Ao meu querido irmão André que de forma especial me deu força e coragem, apoiando-me nos momentos de dificuldades, para enfrentar o mestrado.

Ao meu querido irmão Rafael, pelo incentivo e pela forma grandiosa de ajudar minha família.

Aos meus filhos que iluminam com amor os meus pensamentos: ao Francisco, pela paciência em ensinar-me as novas tecnologias; aos meus filhos Maria Beatriz e Felipe, pela compreensão em escutar "agora não, estou escrevendo minha dissertação".

Em especial ao meu querido esposo João, pelo apoio nos momentos mais difíceis, pelo carinho no dia-a-dia e pelo amor que traz grandes alegrias! 


\section{RESUMO}

COSTA, R. A. Absenteísmo por doenças em docentes do ensino fundamental. 2017. 80 f. Dissertação (Mestrado) - Programa de Mestrado Profissional em Gestão de Organização de Saúde da Faculdade de Medicina de Ribeirão Preto. Universidade de São Paulo, Ribeirão Preto, 2017.

O professor exerce uma das profissões mais estressantes devido a longas jornadas de trabalho, ritmo intenso e diversas variáveis que influenciam em sua vida profissional. As situações variadas do cotidiano da sala de aula têm como resultado fatores físicos e psicológicos, gerando problemas de saúde que podem acarretar o aumento nos índices de absenteísmo, aumentando o número de licenças médicas e a necessidade por parte da organização de reposição de funcionários, transferências e novas contratações. O absenteísmo docente é também apontado, em alguns estudos, como um dos responsáveis pela baixa qualidade da educação brasileira. $\mathrm{O}$ trabalho analisou o absenteísmo por doença dos Professores de Educação Básica II que engloba a Educação Infantil (crianças de 4 e 5 anos) e o Ensino Fundamental I (1 a $5^{\circ}$ ano). Foi analisada a planilha de absenteísmo de 2014, disponibilizada eletronicamente pela Secretaria Municipal de Educação de Ribeirão Preto. Dos 991 professores de PEB II em atividade em 2014, 748 tiraram 4.324 licenças por vários motivos. Deste total, 2003 licenças foram por algum motivo de doença. O total de número de dias perdidos por absenteísmo relacionado à Licença de Tratamento de Saúde, é de 14.957 dias de ausência do docente efetivo. Os professores da faixa etária entre 30 e 40 foram os que mais se ausentaram por motivos de saúde. Os quatro principais motivos do absenteísmo por doenças são por "fatores que influenciam o estado de saúde e o contato com os serviços de saúde", por "doenças relacionadas ao aparelho respiratório, por "transtornos mentais e comportamentais" e por "doenças do sistema osteomuscular e do tecido conjuntivo". Relacionado as escolas ao absenteísmo, conclui-se que quanto maior a complexidade da escola, maior o número de licenças concedidas por motivo de saúde.

Palavras-chave: Absenteísmo. Saúde Profissional. Educação. 


\begin{abstract}
COSTA, R. A. Absenteeism due to diseases in elementary school teachers. 2017. 80 p. Dissertation (MA) - Programa de Mestrado Profissional em Gestão de Organização de Saúde da Faculdade de Medicina de Ribeirão Preto. Universidade de São Paulo, Ribeirão Preto, 2017.
\end{abstract}

The teacher plays one of the most stressful professions due to long working hours, intense pace and several variables that influence in your professional life. Every day, the varied classroom situations are resulting in physical and psychological factors, generating a high level of stress. Health problems can lead to an increase in absenteeism rates, increasing the number of medical licenses and the need for replacement of the organization of employees, transfers and new hires. Teaching absenteeism is also pointed out, in some studies, as one of those responsible for the low quality of Brazilian education. The paper analyzed the sickness absenteeism of the Basic Education Teachers II that includes early childhood education (children 4 and 5 years old) and elementary school (1st to 5 th year). The absenteeism worksheet for 2014 was analyzed, made available electronically by the Municipal Department of Education of Ribeirão Preto. Of the 991 PEB II teachers active in 2014, 748 took out 4,324 licenses for various reasons. Of this total, 2003 licenses were for some reason of illness. The total number of days lost due to absenteeism related to the Health Treatment License is 14,957 days of absence of the effective teacher. Teachers in the age group between 30 and 40 were those who were most absent due to health reasons. The four main reasons for illness absenteeism are "factors influencing health status and contact with health services", "diseases related to the respiratory system," mental and behavioral disorders "and" diseases of the musculoskeletal system and connective tissue". Relating schools to absenteeism, we conclude that the greater the complexity of the school, the greater the number of licenses granted for health reasons.

Keywords: Absenteeism. Professional Health. Education. 


\section{Lista de Gráficos}

Gráfico 1 - Número de professores por gênero............................................... 24

Gráfico 2 - Número de licenças por gênero......................................................25

Gráfico 3 - Número de faltas por causa e idade..............................................28

Gráfico 4 - Número de faltas por faixa etária..................................................... 29

Gráfico 5 - Número de licenças por número de dias afastados...........................30

Gráfico 6 - Número faltas por agrupamento dos capítulos da CID-10..................35

Gráfico 7 - Total de licenças médicas por gênero..............................................40

Gráfico 8 - Percentual de faltas por capítulo da CID-10 e gênero.........................42

Gráfico 9 - Porcentagem das escolas por região..............................................46

Gráfico 10 - Número médio de licenças por motivo de saúde por escolas nas regiões de Ribeirão Preto......................................................................................49

Gráfico 11 - Números de faltas por motivos das licenças e escola......................50

Gráfico 12 - Números de faltas por capítulos da CID-10 e escola........................52 Gráfico 13 - Média das concessões de licenças por escolas e por grau de complexidade das escolas...................................................................................58 


\section{Lista de Tabelas}

Tabela 1 - Motivos das licenças por gênero..................................................26

Tabela 2 - Quantidade e porcentagem das faltas.................................................. 27

Tabela 3 - Quantidade e percentual de faltas por motivo e gênero.................... 27

Tabela 4 - Quantidades de dias por período de licenças......................................31

Tabela 5 - Número de faltas por capítulo da CID-10 e Idade.................................37

Tabela 6 - Porcentagem de capítulos da CID-10 por faixa de idade.....................39

Tabela 7 - Capítulos da CID-10 por número de atestados de LTS/dias................44

Tabela 8 - Resultados da Licença para Tratamento de Saúde (LTS)...................45

Tabela 9 - Escolas por número de faltas por motivos das licenças.....................47

Tabela 10 - Total de escolas por região e dados do absenteísmo........................49

Tabela 11 - Escolas por região, indicador de complexidade, atividade da escola, tamanho médio da sala, notas do IDEB e faltas por motivo de saúde.................53

Tabela 12 - Indicador de complexidade por dados do absenteísmo...................57

Tabela 13 - Número médio e total de licenças concedidas por tipo de licença e faixa educativa principal da unidade escolar.....................................................59

Tabela 14 - Escolas com maior ocorrência de LTS, principais capítulos da CID10 e número de casos............................................................................................61 


\section{Lista de Quadros}

Quadro 1 - Estratégia PICO.............................................................................23

Quadro 2 - Capítulos da CID-10, código e título dos capítulos...........................33

Quadro 3 - Complexidade de gestão dos estabelecimentos de ensino................56 


\section{SUMÁRIO}

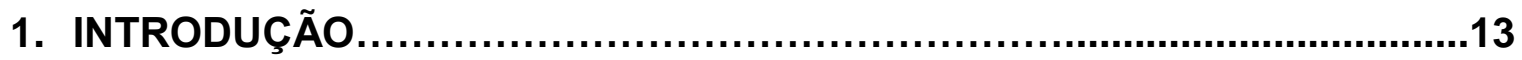

1.1. EDUCAÇÃO E ABSENTEÍSMO DOCENTE...............................................

1.2. A EDUCAÇÃO BÁSICA EM RIBEIRÃO PRETO.....................................17

2. METODOLOGIA

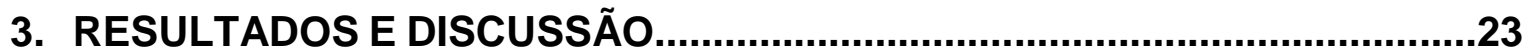

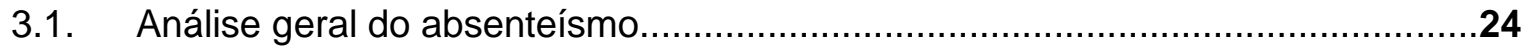

3.2. Análise das ausências por licença de saúde.....................................................32

3.3. Análise do absenteísmo nas Escolas Municipais de PEB II .................................46

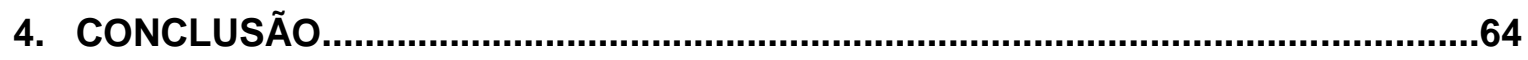

REFERÊNCIAS

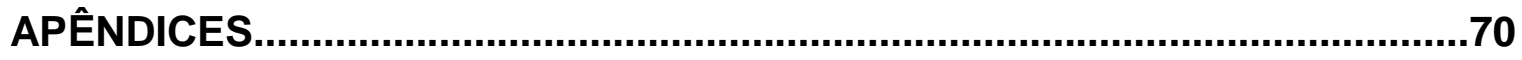

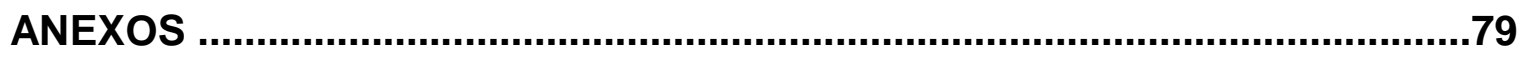




\section{INTRODUÇÃO}

Este trabalho analisou o absenteísmo por doença dos docentes no ensino fundamental em instituições públicas municipais de ensino da cidade de Ribeirão Preto no ano de 2014. Para tal, foi necessário quantificar os números de absenteísmo, separar essas ausências por capítulo da CID-10 e as licenças por motivos variados, que afetaram os professores do PEB II - Professores da Educação Básica II que englobam a Educação Infantil (crianças de 4 e 5 anos) e o Ensino Fundamental I (1을 ao $5^{\circ}$ ano). Foram isoladas e analisadas as licenças médicas dos docentes e quantificadas quais as doenças que mais acometem estes professores, utilizando comparativos com idade, sexo e as escolas em que ocorreram os maiores índices de absenteísmo.

\subsection{Educação e absenteísmo docente}

Segundo Venson et al. (2013), a Qualidade de Vida no Trabalho (QVT) referese à preocupação com a saúde, satisfação e felicidade do trabalhador no exercício de suas funções, englobando aspectos físicos, ambientais, psicológicos e sociais do ambiente de trabalho. A preocupação com a QVT dos profissionais da educação brasileira tem crescido no período recente justamente quando houve uma expansão do próprio sistema educacional brasileiro.

As instituições escolares no Brasil historicamente eram apenas para um restrito grupo de alunos. A partir da década de 1930 se deu um crescimento acelerado emergindo a escola de massa e nos anos mais recentes efetivamente pode se dizer que a maior parte das crianças brasileiras encontra-se no meio escolar, com uma cobertura atingindo mais de $90 \%$ das crianças em idade escolar ao menos na fase dos chamados anos iniciais da educação fundamental.

A história da educação brasileira, segundo Saviani (2008), pode ser dividida em seis períodos. Entre 1549 -1759 ocorreu o primeiro período teve origem com o colégio jesuíta. O segundo período (1759 - 1827) é conhecido como "Aulas Régias" onde pela primeira vez se instaurar uma escola pública estatal inspirada nas ideias iluministas. O terceiro período compreende os anos de 1827-1890, que pela primeira vez tentouse organizar a educação sobre comando do poder público da época, ou seja, o governo imperial e os governos das províncias. Entre 1890-1931 ocorreu o quarto 
período, com a criação das escolas primárias estaduais na forma de grupos escolares. O quinto período (1931-1961) é caracterizado pela regulamentação das escolas superiores, secundárias e primárias. No sexto período, que começou em 1961 e se estende até a atualidade, encontramos a unificação da regulamentação da educação nacional, que abrange toda a rede pública (municipal, estadual e federal) e a rede privada, que juntas foram moldadas segundo uma concepção produtivista de escola e buscaram incorporar a totalidade dos jovens brasileiros, o que passou a ocorrer de modo mais efetivo apenas nos anos 80 .

De acordo com Souza et al. (2003), até os anos de 1960, os profissionais do ensino gozavam de uma relativa segurança material, de emprego estável e de um certo prestígio social. Mas a partir dos anos de 1970, o papel do professor extrapolou a mediação do processo de conhecimento do aluno e ampliou a missão do profissional para além da sala de aula, a fim de garantir uma articulação entre a escola e a comunidade. O professor, além de ensinar, começou a participar da gestão e do planejamento escolares, o que significou uma dedicação mais ampla e estressante.

Cotidianamente, Spósito et al. (2014) procura mostrar que os trabalhadores estão sujeitos a condições estressantes que podem gerar sofrimento, tensão emocional, insatisfação, irritação, insônia e diversas doenças que comprometem a sua saúde. Neste sentido, o professor, segundo os mesmos autores, exerce uma das profissões mais estressantes devido a longas jornadas de trabalho, ritmo intenso e variáveis diversas que influenciam em sua vida profissional e pessoal. O exercício da docência não pode estar separado das condições de trabalho que envolve esta carreira, ou seja, questão salarial, condições precárias de trabalho, jornada excessiva e saúde do professor. O docente está exposto a eventos diversos que afetam sua saúde física e psíquica, proliferando doenças ocupacionais relacionadas diretamente aos professores. As situações variadas do cotidiano da sala de aula têm como resultado fatores relacionados diretamente ao corpo, como a ergonomia inadequada e o uso da voz, fatores psicológicos e a um nível elevado de estresse.

No entendimento de Codo, Sampaio e Hitomi (1994), a organização do trabalho exerce, sobre o homem, uma ação específica, cujo impacto é sobre o aparelho psíquico. Em certas condições, emerge um sofrimento que pode ser atribuído ao choque entre uma história individual, portadora de projetos, de esperanças e de desejos, e uma organização do trabalho que os ignora. Esse sofrimento, de natureza mental, começa quando o homem, no trabalho, já não pode fazer nenhuma 
modificação na sua tarefa no sentido de torná-la mais conforme as suas necessidades fisiológicas e a seus desejos psicológicos, isto é, quando a relação homem-trabalho é bloqueada. Desta forma, quando o trabalho é desprovido de significação, não é reconhecido ou é uma fonte de ameaças à integridade física e/ou psíquica, acaba por determinar sofrimento ao professor. Neste quadro de sofrimento físico e psicológico, uma das consequências pode ser as faltas do docente com suas obrigações profissionais, ou seja, observamos a frequência do absenteísmo.

$O$ processo de constante e acelerada transformação, que a sociedade vive atualmente, impõe um ritmo acelerado de produção tecnológica e altera as relações desenvolvidas no mundo do trabalho, provocando queda crescente na qualidade de vida da população trabalhadora. Esta problemática também está presente na escola que sofre constantemente os impactos das mudanças cientificas, tecnológicas, políticas e econômicas decorrentes destas transformações. Nesse contexto, o ambiente escolar não foge à regra capitalista, para a qual tem sido, cada vez mais, impostas novas demandas no processo de formação de crianças e jovens.

Sendo assim, uma das categorias profissionais que mais tem exigido mudanças é a dos professores, em virtude da intensificação do ritmo de trabalho. Ao professor, era apenas atribuído o papel referente ao ensino de disciplinas, tendo gradativamente assumido novas funções, como construir hábitos de saúde, assessoramento psicológico, atividades voltadas à comunidade fora dos muros escolares. Somado a isso, o docente também enfrenta, especialmente no caso brasileiro, o crescimento de tarefas burocráticas, a falta de autonomia e as carências da infraestrutura do ambiente escolar, as relações conflitantes com familiares de alunos e, principalmente, a baixa remuneração, tornando evidente o quadro crônico de depreciação e desqualificação social, psicológica e biológica desses profissionais. Emerge dessa situação um cenário com efeitos adversos, proporcionando aos docentes um conjunto de malestares, em muitos casos desestabilizando e gerando doenças diversas, que influenciam fortemente na qualidade de vida destes profissionais (ROCHA; FERNANDES, 2008).

Os problemas de saúde podem acarretar o aumento nos índices de absenteísmo, que por sua vez, aumenta o número de licenças médicas, e por consequência, a necessidade por parte da organização de reposição de funcionários, transferências, novas contratações, novos treinamentos, entre outras despesas. 
O absenteísmo docente é também apontado, em alguns estudos, como um dos responsáveis pela baixa qualidade da educação brasileira quando medida por exemplo pelo desempenho dos alunos em testes de proficiência como o PISA Programa Internacional de Avaliação de Estudantes (ORGANISATION FOR ECONOMIC CO-OPERATION AND DEVELOPMENT (OECD), 2013).

Absenteísmo é uma palavra com origem no latim, onde absens significa "estar fora, afastado ou ausente". É uma expressão para designar as ausências dos empregados ao trabalho. Para Chiavenato (2008, p. 88).

Absenteísmo ou absentismo é a frequência e/ou duração do tempo de trabalho perdido quando os colaboradores não comparecem ao trabalho. O absenteísmo constitui a soma dos períodos em que os colaboradores se encontram ausentes do trabalho, seja por falta, por atraso ou algum motivo interveniente.

O absenteísmo é decorrente de um ou mais fatores: sociais, culturais, de personalidade e de doenças. O absenteísmo, assim, é um fenômeno multifatorial (ALTOÉ, 2010). Segundo Silva e Marziale (2000), o absenteísmo pode ser dividido em cinco categorias: absenteísmo voluntário, quando há ausência no trabalho por razões particulares não justificada por doença; absenteísmo por doença, que inclui todas as ausências por doença ou por procedimento médico, excetuam-se os infortúnios profissionais; absenteísmo por patologia profissional, quando ocorre ausências por acidentes de trabalho ou doença profissional; absenteísmo legal, acontece quando há faltas no serviço amparadas por leis, tais como, gestação, nojo, gala, doação de sangue e serviço militar; e absenteísmo compulsório que é impedimento ao trabalho devido a suspensão imposta pelo patrão, por prisão ou outro impedimento que não permita o trabalhador chegar ao local de trabalho.

Uma parte das causas relacionadas ao absenteísmo docente inclui qualidade de vida no trabalho (QVT), e estão relacionadas com a precarização do trabalho, como as condições de trabalho insatisfatório, a falta de valorização do magistério, salários, escassez de recursos humanos, materiais, carga horária, e os problemas de saúde (SANTOS, 2006). Os motivos que fazem com que o professor se ausente no seu trabalho são inúmeros, tais como a violência nas escolas e a precarização da atividade docente que são observados em muitas regiões do país podem estar diretamente relacionados ao elevado número de afastamentos, principalmente por questões ligadas ao sofrimento mental decorrente do trabalho (SILVA et al., 2012). 
Para melhor compreender o absenteísmo docente, é importante contar com o estudo da epidemiologia. Segundo Gordis (2017), a epidemiologia é a base para o desenvolvimento de ações públicas que influenciam a saúde das populações. Para Gordis (2017, p. 352),

(...) a decisão do número e do tipo de dados que necessitamos para prevenção será determinada socialmente, dependendo dos valores e prioridades de uma sociedades. A epidemiologia, em conjunto com outras disciplinas, pode fornecer muitos dados científicos necessários que são relevantes para a questão de risco e prevenção.

Com o estudo sobre o absenteísmo, as políticas públicas podem agir no campo da prevenção e controle para diminuir os problemas de saúde nas populações e melhorar a saúde e as condições de vida e de trabalho dos docentes.

Por outro lado, segundo Gatti (2004), os dados quantitativos com boas escolhas metodológicas trazem subsídios concretos para compreender diversos fenômenos educacionais, contribuindo assim para a produção de políticas educacionais, para o planejamento e gestão educacional.

\subsection{A Educação Básica em Ribeirão Preto}

O Município de Ribeirão Preto, em 2014, contava com um total de 309 estabelecimentos de ensino voltados à educação básica: 74 estaduais, 106 municipais, 208 particulares e nenhum estabelecimento do governo federal. As matrículas em Ribeirão Preto são eminentemente urbanas havendo apenas dois estabelecimentos rurais controlados pelo governo do Estado (INSTITUTO NACIONAL DE ESTUDOS E PESQUISA EDUCACIONAIS ANÍSIO TEIXEIRA (INEP), 2016).

Sobre as diferentes etapas de ensino em Ribeirão Preto, nota-se que as instituições da Rede Municipal se dedicam à educação infantil e ao ensino fundamental, já as escolas estaduais, apesar de um pequeno número dedicado a educação infantil, dominam a educação pública do ensino médio (sendo apenas uma com educação profissional integrada com ensino integral) e reparte com o município a responsabilidade pela educação pública fundamental. O setor privado está presente em todas as etapas de ensino, do ensino infantil ao ensino médio (INEP, 2016).

Em 2014, as 106 escolas Municipais de Ribeirão Preto totalizaram 3.068 docentes, atendendo 42.835 de alunos em toda a Rede. Deste total de docentes, 991 
professores atuaram como PEB II. Já o número total de alunos atendidos pelos professores de Educação Básica Il foi de 21.260 (RIBEIRÃO PRETO, 2015).

Das 106 escolas municipais, 75 escolas atendiam Educação Infantil e Ensino Fundamental I. Desta forma, a análise deste trabalho se restringiu aos professores efetivos e eventuais PEB II - Professores da Educação Básica II que englobavam a Educação Infantil (crianças de 4 e 5 anos) e o Ensino Fundamental I (1ํㅜ a $5^{\circ}$ ano) presentes em 75 escolas (Apêndice A) e professores de PEBII que foram removidos para trabalharem no Departamento de Educação. Ressalta-se que, mesmo algumas escolas também atendendo o Ensino Fundamental II de 6ํㅜ ao 9o ou Ensino Médio, foi analisado apenas a parcela de professores referente ao PEB II

Segundo o Sistema Eletrônico do Serviço de Informação ao Cidadão da Prefeitura Municipal de Ribeirão Preto (RIBEIRÃO PRETO, 2015), as escolas que englobavam PEB II eram assim divididas em 2014:

- 42 Escolas Municipais de Educação Infantil - EMEls (crianças de 4 e 5 anos);

- 2 Centros de Educação Infantil - CEls (crianças de 4 e 5 anos);

- 25 Escolas Municipais de Ensino Fundamental - EMEFs (crianças de 1ำ ao $5^{\circ}$ ano);

- 3 Centros Municipais de Educação Integrada - CEMEls (crianças de $1^{\circ}$ ao $5^{\circ}$ ano);

- 2 Escolas Municipais de Ensino Fundamental e Médio - EMEFEMs (crianças de $1^{\circ}$ a $5^{\circ}$ ano);

- 1 Centro de Educação Especial e Ensino Fundamental - CEEEF (1ํao $5^{\circ}$ ).

Ressalta-se que as Escolas Municipais de Ensino Fundamental - EMEFs, os Centros Municipais de Educação Integrada - CEMEls, as Escolas Municipais de Ensino Fundamental e Médio - EMEFEMs, Centro de Educação Especial e Ensino Fundamental - CEEEF atendem várias séries, mas análise deste trabalho foi feita apenas com professores de Educação Infantil (4 e 5 anos) e Ensino Fundamental I (1ํㅜㄹ ao $5^{\circ}$ ano). 


\section{METODOLOGIA}

Foram utilizados para realização deste trabalho os seguintes descritores: Absenteísmo, Epidemiologia Descritiva, Saúde Profissional, Qualidade de Vida no Trabalho (QVT) e Educação.

O trabalho analisou o absenteísmo dos professores do PEB II - Professores da Educação Básica II que englobam a Educação Infantil (crianças de 4 e 5 anos) e o Ensino Fundamental I ( $1^{\circ}$ a $5^{\circ}$ ano). Segundo documento emitido pelo Sistema Eletrônico do Serviço de Informação ao Cidadão da Prefeitura Municipal de Ribeirão Preto (RIBEIRÃO PRETO, 2015):

Informamos que a atuação docente da rede municipal de ensino de Ribeirão Preto
está descrita na Lei Complementar 2.524/12 (Estatuto do Magistério Municipal),
Capítulo II, Seção I, Artigo 40, conforme segue: CAPÍTULO II DA CARREIRA DO
MAGISTÉRIO Seção I DA CONFIGURAÇÃO DA CARREIRA E DO CAMPO DE
ATUAÇÃO DOS PROFISSIONAIS DO MAGISTÉRIO Artigo 40 - A carreira do
magistério municipal fica configurada nas seguintes categorias profissionais com os
respectivos campos de atuaçãa: I - ÁREA DE DOCÊNCIA a) Professor de Educação
Básica I: atuação na Educação Infantil com crianças de 0 (zero) a 3 (três) anos; b)
Professor de Educação Básica II: atuação na Educação Infantil com crianças de 4
(quatro) e 5 (cinco) anos e nos anos iniciais do Ensino Fundamental (10 ao 50 ano);
c) Professor de Educação Básica III: atuação nos anos finais do Ensino
Fundamental (60 ao 9o ano) e no Ensino Médio; d) Professor de Educação Básica
III, efetivo em área de Educação Especial: atuação na Educação Infantil e no Ensino
Fundamental e Médio, em todos os níveis e modalidades. e) Monitores do CEEEF
"Egydio Pedreschi" e Monitores da EMEPB "Dr. Celso Charuri. (Incluído pela Lei
Compl. no $2.668 / 2014$ ).

O Departamento de Recursos Humanos da Secretaria Municipal da Administração da Prefeitura Municipal de Ribeirão Preto disponibilizou, através de sistema eletrônico, via Divisão de Medicina e Segurança do Trabalho, as informações em Planilha Excel sobre o absenteísmo dos docentes de PEB II no ano de 2014.

A pesquisa utilizou a análise quantitativa de natureza descritiva, e de investigação explicativa, cujo foco foi a análise das faltas dos professores da Rede Municipal de Ribeirão Preto. De acordo com as informações do Sistema Eletrônico do Serviço de Informação ao Cidadão da Prefeitura Municipal de Ribeirão Preto, realizadas em outubro de 2015, a Rede Municipal de Educação em 2014 tinha um total de 991 professores PEB II (RIBEIRÃO PRETO, 2015).

Deste total de professores de PEB II, foram analisadas as várias causas dos absenteísmos de 748 docentes que solicitaram algum tipo de licença, ou seja, 75,47\% dos professores ativos em 2014 tiraram algum tipo de licença. Esses professores 
tiveram um montante de 4324 licenças. Destes afastamentos por vários motivos, foram analisados os 2003 absenteísmos por doença.

O total de absenteísmo, dos docentes de Educação Básica II da Rede Municipal de Ribeirão Preto, está distribuído nas 75 escolas e no Departamento de Educação que também possui professores de Educação Básica II que foram removidos para trabalharem neste Departamento. Destas referidas escolas, a Secretaria da Educação disponibilizou por meio eletrônico uma planilha com os dados do absenteísmo de todos os docentes nomeados PEB II do ano de 2014. Os dados foram tratados e analisados, mantendo em sigilo os nomes dos professores e das escolas

Para Minayo (2001), a análise de conteúdo é compreendida como um conjunto de técnicas. A análise de informações sobre o comportamento humano tem duas funções, sendo elas a verificação de hipóteses e/ou questões e a descoberta do que está por trás dos conteúdos manifestos.

Para definir a metodologia foi utilizada a estratégia denominada PICO, na qual os acrônimos são P - Population - população/tipo de doente e condição; I Intervention - intervenção ou situação de interesse; C - Comparison - comparação ou controle; O - Outcome - desfecho/resultado. (SANTOS et al., 2007)

Segundo o autor supracitado, a estratégia PICO pode ser utilizada para construir questões de pesquisa de naturezas diversas provenientes do cuidado/assistência, do gerenciamento de recursos humanos e materiais, da busca de instrumentos para avaliação de sintomas.

Para a realização deste trabalho, observa-se o seguinte protocolo PICO:

- População - Professores de Educação Básica II da Rede Municipal de Educação de Ribeirão Preto afastados por licença médica de suas atividades profissionais.

- Intervenção - Não será realizada nenhuma intervenção junto ao professores.

- Controle ou comparação - Não será realizado nenhum controle junto aos professores.

- Desfecho - Análise dos conteúdos dos atestados médicos que estão arquivados na Secretaria Municipal de Educação de Ribeirão Preto, prevendo as seguintes informações de 2014: quantidade e motivos do 
absenteísmo, tempo de afastamento, CID-10 (Classificação Internacional da doença), sexo, idade e escola (local de trabalho do docente)

Para organizar o estudo da população, os professores analisados foram divididos por gênero e por faixa etária. A divisão da faixa etária ficou assim definida: 20 a 29 anos, 30 a 39 anos, 40 a 49 anos e acima de 60 anos.

Ressalta-se que não foram divulgados os dados individuais de cada professor, os dados foram tratados agregadamente envolvendo tendências em um estudo histórico-descritivo.

O trabalho foi aprovado pelo comitê de ética sob processo HCRP № 14621/2016 (Anexo A), bem como foi aceita a solicitação de dispensa de aplicação do Termo de Consentimento Livre e Esclarecido (Anexo B).

O presente trabalho teve como objeto de estudo a população dos docentes da educação Infantil (4 e 5 anos) e do Ensino Fundamental I (PEB II) da Rede Municipal de Ribeirão Preto, para estudo desta população foi usada a epidemiologia descritiva.

Segundo Franco e Passos (2011), a epidemiologia descritiva estuda os padrões de ocorrência de doença em uma população, nível coletivo, em função de variáveis ligadas ao tempo, ao espaço e à pessoa. Refere-se às circunstâncias em que as doenças e agravos à saúde ocorrem nas coletividades. A epidemiologia descritiva objetiva responder onde, quando e sobre quem ocorre determinado agravo à saúde. De acordo com o autor citado acima: "Os dados descritivos são elementos importantes para a avaliação das condições de saúde de uma comunidade, orientando as ações a serem desenvolvidas".

Esses elementos permitiram a observação de associações estatísticas e as informações obtidas de "estudos descritivos são úteis para os administradores de saúde pública, planejar e avaliar ações de saúde e para definir prioridades e alocação de recursos" (FRANCO; PASSOS, 2011).

De acordo com a epidemiologia descritiva, para analisar o absenteísmo dos professores da Rede Municipal de Educação, o primeiro passo, para o entendimento de um problema de saúde, foi descrevê-lo pelas variáveis de pessoa, lugar e tempo.

Para a análise das licenças médicas, foi utilizado a Classificação Estatística Internacional de Doenças e Problemas Relacionados à Saúde (também conhecida como Classificação Internacional de Doenças - CID-10) que é publicada pela Organização Mundial de Saúde (OMS) e visa padronizar a codificação de doenças e outros problemas relacionados à saúde. A CID-10 fornece códigos relativos à 
classificação de doenças e de uma grande variedade de sinais, sintomas, aspectos anormais, queixas, circunstâncias sociais e causas externas para ferimentos ou doenças. A cada estado de saúde é atribuída uma categoria única à qual corresponde um código da CID-10.

Para a análise deste trabalho, foram tabulados as CID -10 e depois agrupadas em 22 capítulos já estabelecidos pela própria Classificação Estatística Internacional de Doenças e Problemas Relacionados à Saúde: CID-10, conforme disponibilizado no site do Centro Colaborador da OMS para a Classificação de Doenças em Português (ORGANIZAÇÃO MUNDIAL DE SAÚDE (OMS), 2008):

\footnotetext{
Capítulo I - Algumas doenças infecciosas e parasitárias (A00-B99)

Capítulo II- Neoplasias [tumores] (C00-D48)

Capítulo III- Doenças do sangue e dos órgãos hematopoiéticos e alguns transtornos imunitários (D50-D89)

Capítulo IV- Doenças endócrinas, nutricionais e metabólicas (E00-E90)

Capítulo V - Transtornos mentais e comportamentais (F00-F99)

Capítulo VI - Doenças do sistema nervoso (G00-G99)

Capítulo VII - Doenças do olho e anexos (H00-H59)

Capítulo VIII - Doenças do ouvido e da apófise mastoide (H60-H95)

Capítulo IX - Doenças do aparelho circulatório (100-199)

Capítulo X- Doenças do aparelho respiratório (J00-J99)

Capítulo XI - Doenças do aparelho digestivo (K00-K93)

Capítulo XII- Doenças da pele e do tecido subcutâneo (L00-L99)

Capítulo XIII - Doenças do sistema osteomuscular e do tecido conjuntivo (M00-M99)

Capítulo XIV - Doenças do aparelho geniturinário (N00-N99)

Capítulo XV - Gravidez, parto e puerpério (O00-O99)

Capítulo XVI - Algumas afeç̧ões originadas no período perinatal (P00-P96)

Capítulo XVII- Malformações congênitas, deformidades e anomalias cromossômicas (Q00-Q99)

Capítulo XVIII - Sintomas, sinais e achados anormais de exames clínicos e de laboratório, não classificados em outra parte (R00-R99)

Capítulo XIX- Lesões, envenenamento e algumas outras consequências de causas externas (S00-T98)

Capítulo XX - Causas externas de morbidade e de mortalidade (V01-Y98)

Capítulo XXI - Fatores que influenciam o estado de saúde e o contato com os serviços de saúde (Z00-Z99)

Capítulo XXII - Códigos para propósitos especiais (U00-U99)
}

Para analisar o absenteísmo das escolas da Rede Municipal de Ribeirão Preto que atendem Educação Básica II que englobam a Educação Infantil (crianças de 4 e 5 anos) e o Ensino Fundamental I (1ำ a $5^{\circ}$ ano), optou-se por não colocar os nomes das Escolas, fazendo referência das mesmas por numeração de forma aleatória (Escola 1, Escola 2, Escola 3 e assim sucessivamente). 


\section{RESULTADOS E DISCUSSÃO}

De acordo com os dados e seguindo o protocolo PICO, a População analisada foi de 748 professores estatutários e eventuais da Rede Municipal de Educação de Ribeirão Preto que foram afastados por licença médica de suas atividades profissionais. Ressalta-se que não foi realizada nenhuma Intervenção nem o Controle (comparação) junto a esses professores. O Desfecho desde trabalho foi focado na análise dos conteúdos dos atestados médicos do ano letivo de 2014, que estão arquivados na Secretaria Municipal de Educação de Ribeirão Preto, o Quadro 1 apresenta estas informações.

Quadro 1 - Estratégia PICO

\begin{tabular}{|l|l|}
\hline Acrônimos & Análise \\
\hline População & $\begin{array}{l}748 \quad \text { Professores (PEBII) que } \\
\text { tiveram absenteísmo }\end{array}$ \\
\hline Intervenção & Nenhuma \\
\hline Controle & Nenhuma \\
\hline Desfecho & $\begin{array}{l}2003 \text { Licenças Médicas - 14.957 } \\
\text { dias de afastamento dos docentes } \\
\text { Total 4.323 licenças por motivos } \\
\text { variados 22.445 dias de } \\
\text { afastamento }\end{array}$ \\
\hline
\end{tabular}

Fonte: Elaborado pelo autor com base nos dados Ribeirão Preto, 2015.

Após a tabulação dos dados, fornecidos pela Secretaria de Educação, foi possível construir uma série de análises para melhor visualizar o problema do absenteísmo na Rede Municipal de Educação. 


\subsection{Análise geral do absenteísmo}

Dos 991 professores que atuaram como PEB II em 2014, 748, ou seja, 75,47\%, tiveram algum tipo de absenteísmo no trabalho e 243 docentes $(24,53 \%)$, a princípio, não se ausentaram nenhum dia de suas atividades profissionais em 2014.

Os 748 docentes somaram 4.323 licenças por motivos variados. Destes docentes que tiraram licenças, apenas 24 são do sexo masculino (3,2\%), sendo a maioria (724) do sexo feminino, totalizando $96,8 \%$, como se pode ver no Gráfico 1.

Gráfico 1 - Número de professores por gênero

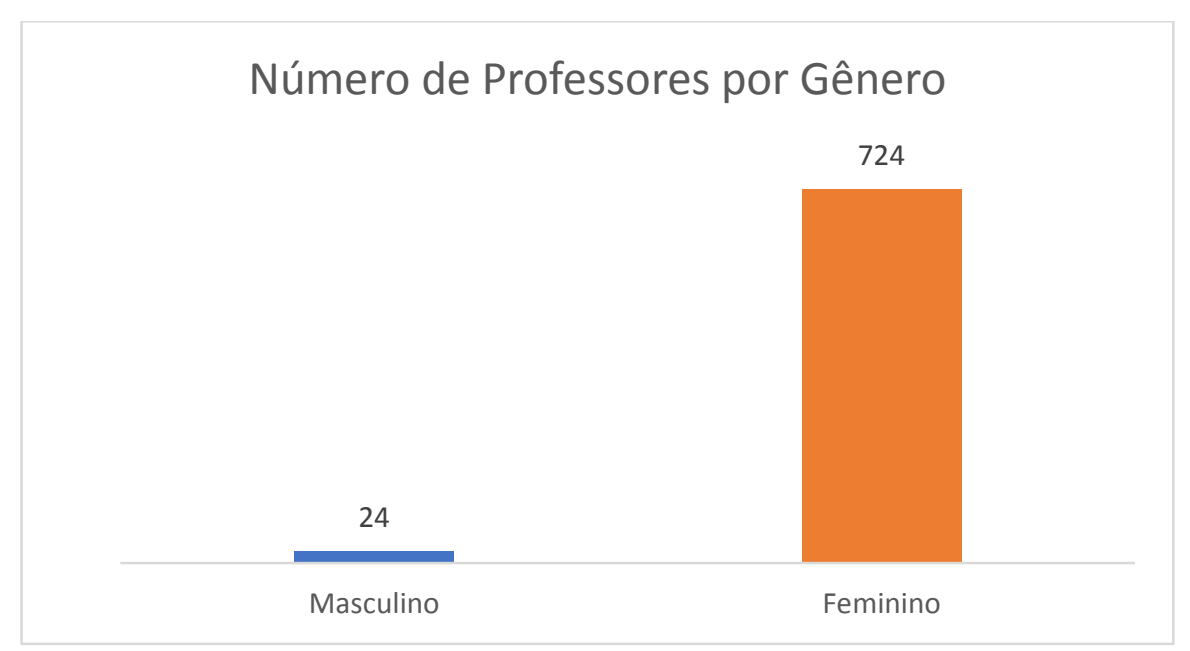

Fonte: Elaborado pelo autor com base nos dados Ribeirão Preto, 2015.

O Gráfico 2 separa o total de licenças por gênero. Este gráfico mostra que as mulheres docentes da Educação Básica II obtiveram 4.206 licenças (97,3\%). Já os homens tiraram 117 licenças (2,7\% do total). Assim, às mulheres que tiraram licenças foram concedidas em média, 5,8 licenças e aos homens (que tiraram licença) foram concedidas 4,8 licenças em média. 
Gráfico 2 - Número de licenças por gênero

\section{Número de Licenças por Gênero}

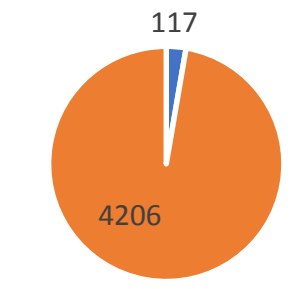

- Masculino - Feminino

Fonte: Elaborado pelo autor com base nos dados Ribeirão Preto, 2015.

As faltas dos docentes de Educação Básica II foram classificadas em sete categorias: Faltas Abonada, Licenças por Motivo de Saúde (com CID-10), Licença Gala, Prorrogação Licença Gestante (sem CID-10), Licença Nojo, Licença Prêmio e outros (dispensas não definidas). Os dados das Prorrogações Licenças Gestantes não entraram na categoria Licenças por Motivos de Saúde, pois nos dados primários, eles estão assim nomeados e sem a Classificação Internacional de Doenças - CID-10, por isso não foram agrupados juntamente com as Licenças por Motivo de Saúde.

Com relação ao percentual de licenças por razões do absenteísmo dos professores de Educação Básica II em 2014, nota-se um total de 4.324 licenças de ambos os sexos, sendo que em primeiro lugar tem-se 2.095 licenças que estão relacionadas à Faltas Abonadas, ou seja, sem justificativas, pois são permitidas pela Lei dos direitos do servidor público. O alto índice de absenteísmo por Faltas Abonadas também traz preocupação e prejuízos para o Ensino Fundamental I se considerar que um dia de falta de um docente pode significar várias aulas sem o docente, afetando um número significativo de alunos. Em segundo lugar, tem-se os afastamentos por Motivo de Saúde que somam 2003 licenças.

A Tabela 2 mostra, de forma comparativa, a quantidade e porcentagem de cada de cada motivo de absenteísmo dos docentes de Educação Básica II de 2104. A Licença Prêmio foi concedida a 112 docentes. Licença Nojo foi tirada por 49 professores. 26 mulheres tiveram afastamento por Prorrogação Licença Gestante. A Licença Gala foi solicitada por 17 docentes e 21 professores se afastaram por outros motivos. 
Tabela 1- Quantidade e porcentagem das faltas

\begin{tabular}{lcc}
\hline Tipo de Falta & Quantidade & Porcentagem \\
\hline Falta Abonada & 2095 & $48,5 \%$ \\
Licença por Motivo de Saúde & 2003 & $46,3 \%$ \\
Licença Prêmio & 112 & $2,6 \%$ \\
Licença Nojo & 49 & $1,1 \%$ \\
Gestante/Prorrogação Licença & 26 & $0,6 \%$ \\
Outros & 21 & $0,5 \%$ \\
Licença Gala & 17 & $0,4 \%$ \\
\hline
\end{tabular}

Fonte: Elaborado pelo autor com base nos dados Ribeirão Preto, 2015.

A Tabela 1 também mostra em porcentagem os motivos do absenteísmo dos 748 professores de Educação Básica II em 2014: Falta Abonada atingiu 48,5\%; Licenças por Motivo de Saúde são 46,3\% do absenteísmo; Licença Prêmio teve 2,6\%; Licença Nojo totalizou 1,1\%; Prorrogação de Licença Gestante apenas 0,6\%; outros (motivos das licenças não especificados ou sem CID-10) que somam 0,5\% e Licença Gala teve o percentual de $0,4 \%$.

Mesmo o absenteísmo por doença estando em segundo lugar na lista dos motivos de ausência dos docentes (PEB II) da Rede Municipal, é alto o número de faltas por Motivo de Saúde dos professores da Rede, considerando que o atestado médico pode conter Licença para Tratamento de Saúde - LTS - de até 15 dias, licenças de mais de 16 dias, 30 dias, 90 ou 120 dias. Desta forma, o número de licenças não corresponde ao número de dias afastado, ou seja, o total de dias de afastamento por doença é maior que os dias de apenas abonadas.

Das 4.206 licenças concedidas ao gênero feminino, 2.022 (96,5\%) são Faltas Abonadas permitidas pelo Lei Municipal de Educação e 1968 (98,3\%) são por Motivos de Saúde. Já as 117 licenças masculinas são assim distribuídas: 73 (3,5\%) Faltas Abonadas e 35 (1,7\%) por Motivos de Saúde (Tabela 2).

Porém, relativamente, as causas do absenteísmo dos docentes de PEB II ao gênero dos mesmos, observa-se que as mulheres se abstiveram mais, por Motivo de Saúde, das suas atividades profissionais do que os homens que se ausentaram mais por faltas abonadas (Tabela 3). 
A Tabela 3 mostra que as 724 professoras (PEB II) em 2014 que tiraram 1968 licenças para tratamento de saúde, ou seja, $46,8 \%$ do total das mulheres tiraram licença por Motivo de saúde. E os 24 professores de PEB II tiraram 35 licenças por Motivos de Saúde, ou seja, 29,4\% tiraram licenças por Motivo de Saúde.

As faltas abonadas tiveram os seguintes resultados: mulheres tiraram 2022 Licenças Abonadas (48,1\%das faltas) e os homens tiveram 73 abonadas $(62,4 \%)$. Ressalta-se que as mulheres têm mais faltas por Motivo de Saúde e os homens mais faltas abonadas.

Tabela 2 - Tipos das licenças por gênero

\begin{tabular}{lccccc}
\hline \multirow{2}{*}{ Tipo de Falta } & \multicolumn{2}{c}{ Quantidade } & \multicolumn{2}{c}{ Porcentagem } & \multirow{2}{*}{ Total } \\
\cline { 2 - 5 } & Mulheres & Homens & Mulheres & Homens & \\
\hline Falta Abonada & 2022 & 73 & $96,5 \%$ & $3,5 \%$ & 2095 \\
Licenças por Motivos de Saúde & 1968 & 35 & $98,3 \%$ & $1,7 \%$ & 2003 \\
Licença Gala & 16 & 1 & $94,1 \%$ & $5,9 \%$ & 17 \\
Prorrogação Licença Gestante & 26 & 0 & $100,0 \%$ & $0,0 \%$ & 26 \\
Licença Nojo & 46 & 3 & $93,9 \%$ & $6,1 \%$ & 49 \\
Licença Prêmio & 110 & 2 & $98,2 \%$ & $1,8 \%$ & 112 \\
Outros & 18 & 3 & $85,7 \%$ & $14,3 \%$ & 21 \\
Total de Faltas & 4206 & 117 & $97,3 \%$ & $2,7 \%$ & 4323 \\
\hline
\end{tabular}

Fonte: Elaborado pelo autor com base nos dados Ribeirão Preto, 2015.

Tabela 3 - Quantidade e percentual de faltas por motivo e gênero

\begin{tabular}{lcccc}
\hline \multirow{2}{*}{\multicolumn{1}{c}{ Tipo de Falta }} & \multicolumn{2}{c}{ Quantidade } & \multicolumn{2}{c}{$\begin{array}{c}\text { Porcentagem sobre o } \\
\text { Gênero }\end{array}$} \\
\cline { 2 - 5 } & Mulheres & Homens & Mulheres & Homens \\
\hline Falta Abonada & 2022 & 73 & $48,1 \%$ & $62,4 \%$ \\
Licença por Motivo de Saúde & 1968 & 35 & $46,8 \%$ & $29,9 \%$ \\
Licença Gala & 16 & 1 & $0,4 \%$ & $0,9 \%$ \\
Prorrogação Licença Gestante & 26 & 0 & $0,6 \%$ & $0,0 \%$ \\
Licença Nojo & 46 & 3 & $1,1 \%$ & $2,6 \%$ \\
Licença Prêmio & 110 & 2 & $2,6 \%$ & $1,7 \%$ \\
Outros & 18 & 3 & $0,4 \%$ & $2,6 \%$ \\
Total de Faltas & 4206 & 117 & $100,0 \%$ & $100,0 \%$ \\
\hline
\end{tabular}

Fonte: Elaborado pelo autor com base nos dados Ribeirão Preto, 2015.

Confrontando as causas do absenteísmo com a idade dos professores que tiraram licenças, produziu-se o Gráfico 3. Neste gráfico, observa-se que o pico de Licenças por Motivo de Saúde está aos 35 anos. Mas o absenteísmo por motivo de 
saúde se mantém alto entre a faixa etária de 30 a 50 anos. A partir dos 54 anos cai consideravelmente as Licenças por Motivo de Saúde.

Gráfico 3 - Número de faltas por causa e idade

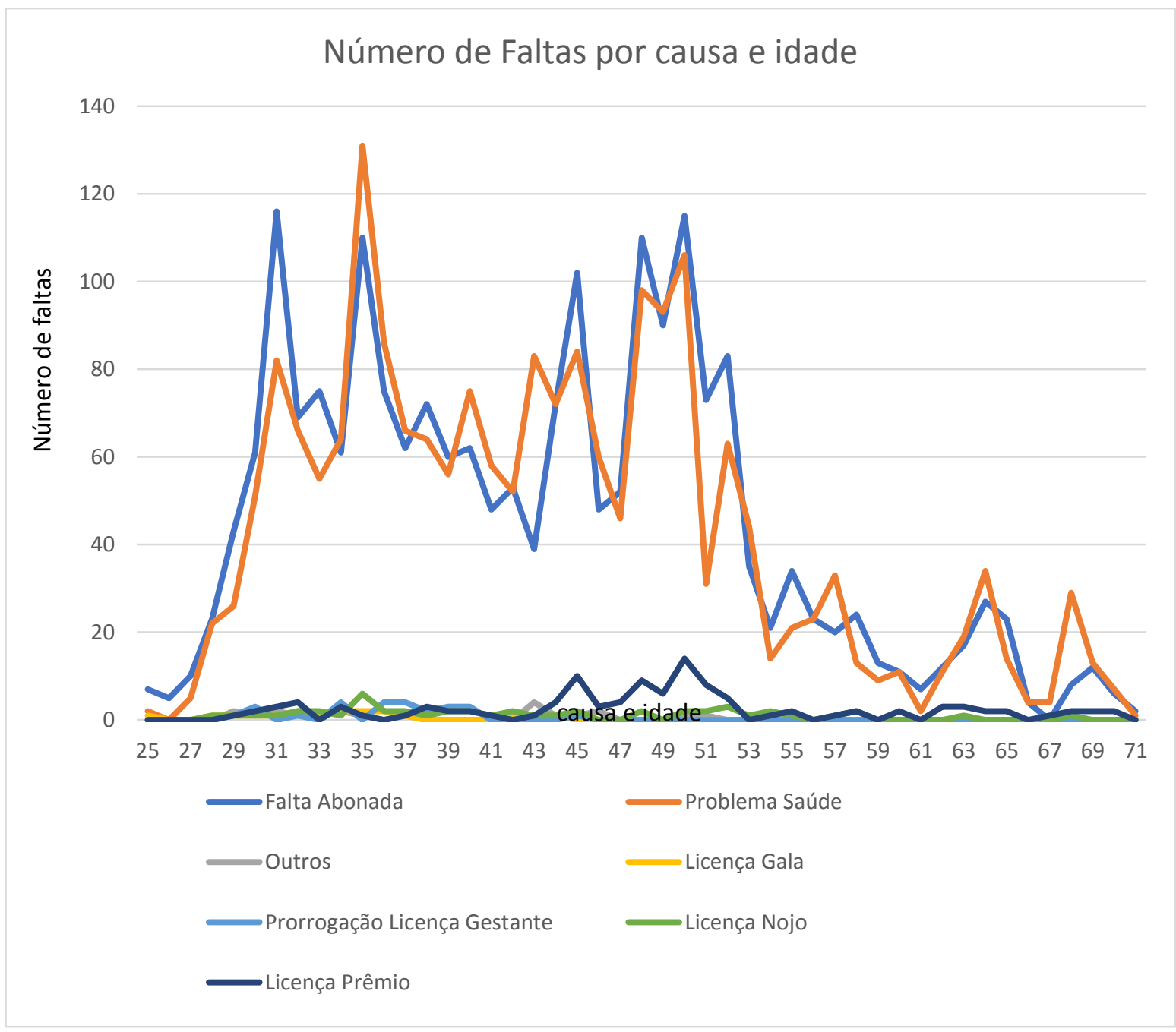

Fonte: Elaborado pelo autor com base nos dados Ribeirão Preto, 2015.

Dos Professores de Educação Básica II da Rede Municipal de Educação de Ribeirão Preto, as faixas etárias que mais tiraram Licenças por Motivo de Saúde foram as que estão entre 30 a 39 anos e 40 a 49 anos. Estas faixas etárias também são as que mais têm Faltas Abonadas (Gráfico 4). 
Gráfico 4 - Número de faltas por faixa etárias

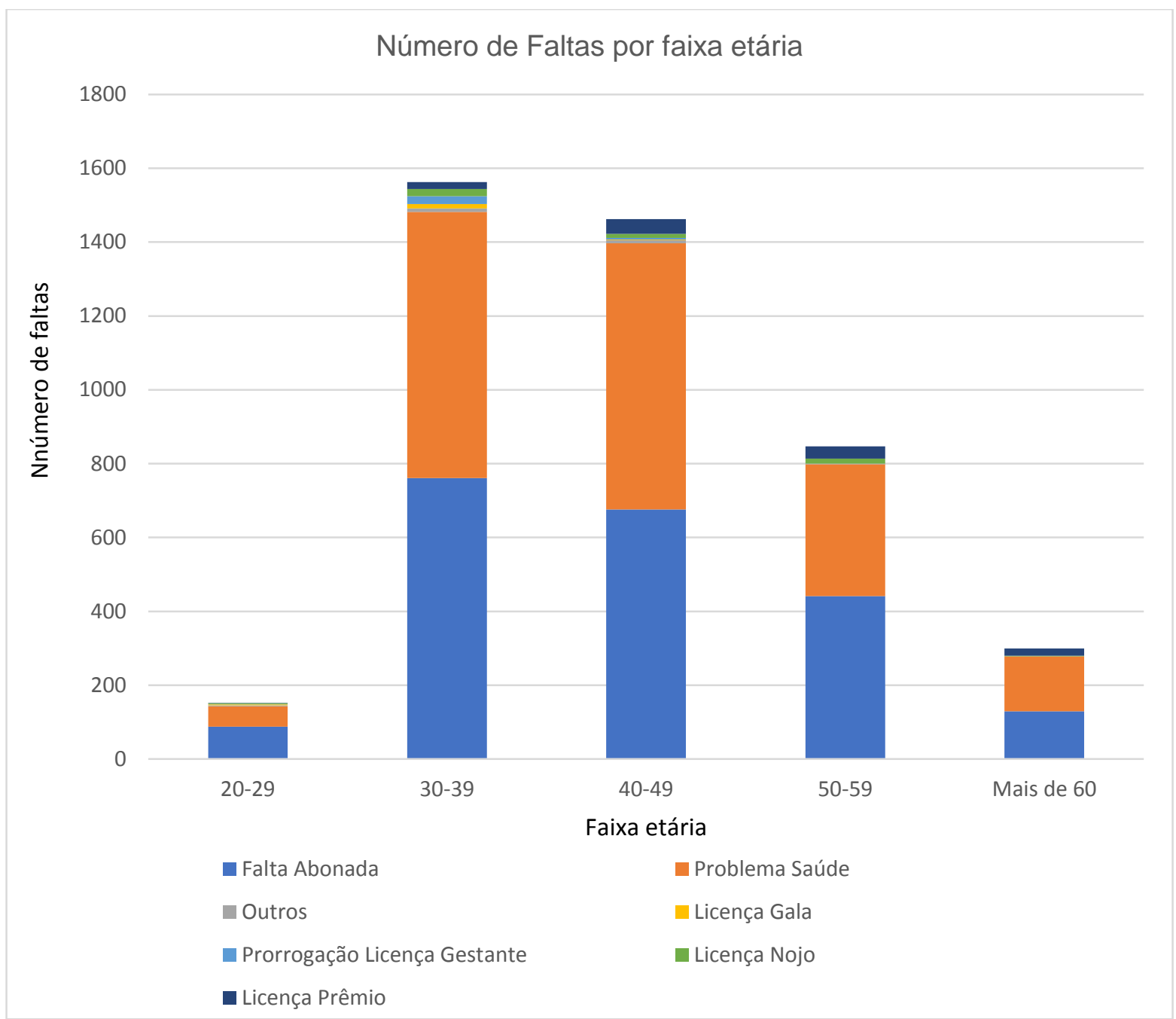

Fonte: Elaborado pelo autor com base nos dados Ribeirão Preto, 2015.

O Gráfico 5 diz respeito ao número de todos os tipos de licenças por dia de afastamentos. $O$ ano de 2014 teve o total de 4.323 licenças que são multiplicadas pelos dias de afastamento que cada licença permitia. Sendo assim, encontra-se 3.132 licenças de 1 dia, 268 licenças de 2 dias, 127 de 3 dias, 73 de 4 dias e assim sucessivamente. Totalizando 22.445 dias de afastamento concedidos a 748 professores que se afastaram de suas atividades profissionais. 
Gráfico 5 - Número de licenças por número de dias afastados

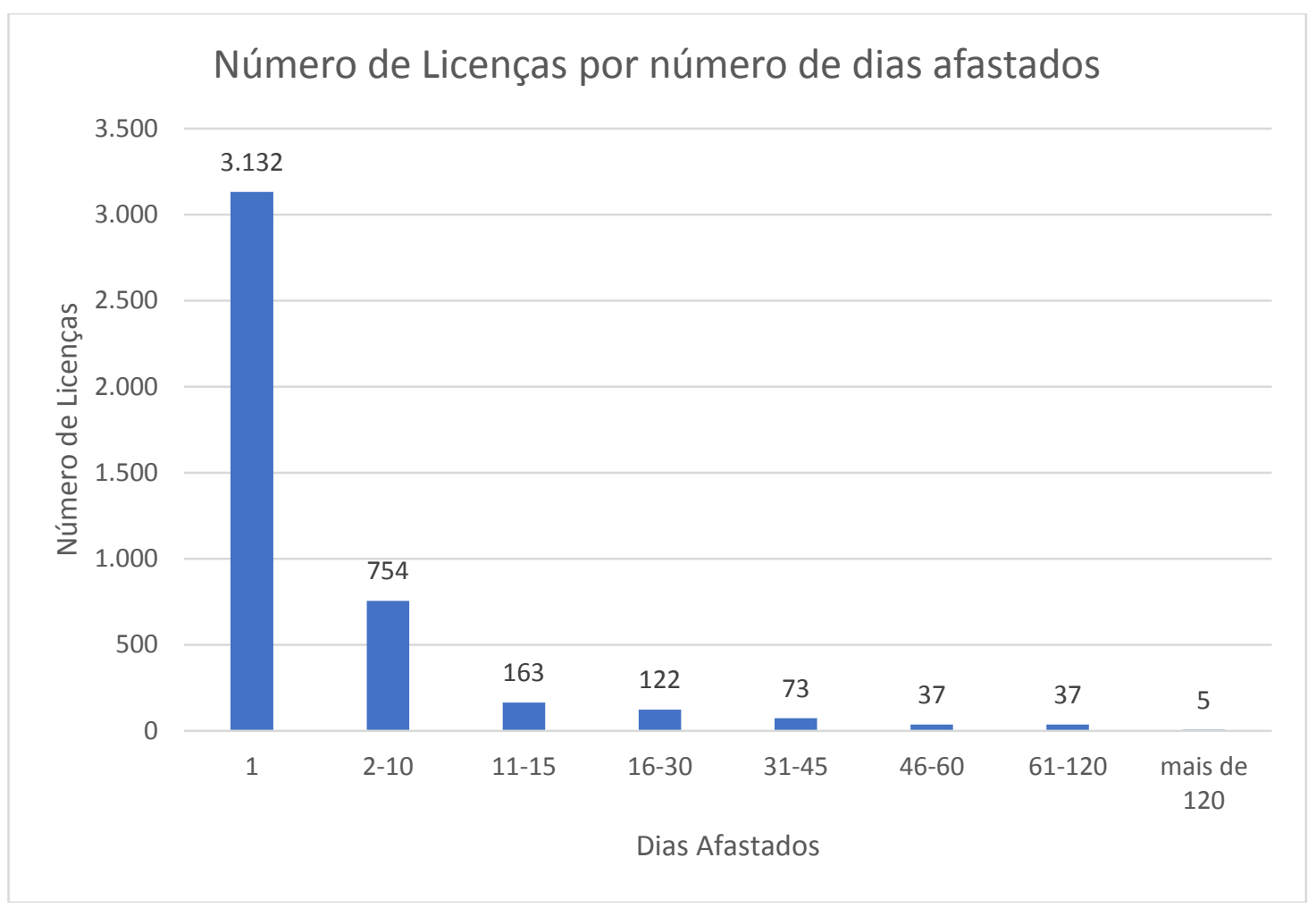

Fonte: Elaborado pelo autor com base nos dados Ribeirão Preto, 2015.

A Tabela 4 apresenta a quantidade de dias de ausências por cada período de licença. Observa-se que as 3132 licenças tiradas de 1 dia, 72,4\% do total de licenças, totalizaram obviamente 3132 dias de afastamento, mas apenas $14 \%$ dos dias de licença. Já as licenças de até 10 dias somaram 3355 dias, as licenças de até 15 dias totalizaram 2334 dias, para os afastamentos de até 30 dias a soma foi de 3239 dias de ausência, as licenças de até 45 dias somam o montante foi de 2955 dias, as licenças de até 60 dias totalizam 2169 dias, e os afastamento de até 120 dias, 3960 dias e licenças com mais de 120 dias a soma foi de 1301 dias. 
Tabela 4 - Quantidades de dias por período de licenças

\begin{tabular}{|c|c|c|c|c|c|c|c|c|}
\hline \multirow[b]{2}{*}{ Motivos das licenças } & \multicolumn{8}{|c|}{ Números de dias de Licenças } \\
\hline & $\begin{array}{c}1 \\
\text { dia }\end{array}$ & $\begin{array}{l}\text { até } 10 \\
\text { dias }\end{array}$ & $\begin{array}{l}\text { até } 15 \\
\text { dias }\end{array}$ & $\begin{array}{l}\text { até } \\
30 \\
\text { dias }\end{array}$ & $\begin{array}{c}\text { até } \\
45 \\
\text { dias }\end{array}$ & $\begin{array}{l}\text { até } \\
60 \\
\text { dias }\end{array}$ & $\begin{array}{l}\text { até } \\
120 \\
\text { dias }\end{array}$ & $\begin{array}{c}\text { mais } \\
\text { de } \\
120 \\
\text { dias }\end{array}$ \\
\hline $\begin{array}{l}\text { Algumas doenças infecciosas e } \\
\text { parasitárias }\end{array}$ & 59 & 126 & - & - & - & - & - & - \\
\hline Doenças da pele e do tecido subcutâneo & 22 & 27 & 24 & - & - & - & - & - \\
\hline Doenças do aparelho circulatório & 31 & 107 & 101 & 49 & 310 & - & - & - \\
\hline Doenças do aparelho digestivo & 96 & 104 & 156 & - & 37 & 55 & - & - \\
\hline Doenças do aparelho geniturinário & 69 & 72 & 72 & 30 & 45 & - & - & - \\
\hline Doenças do aparelho respiratório & 125 & 300 & 45 & - & - & - & - & - \\
\hline \multirow{2}{*}{$\begin{array}{l}\text { Doenças do olho e anexos } \\
\text { Doenças do ouvido e da apófise } \\
\text { mastoide }\end{array}$} & 33 & 177 & 11 & - & - & - & - & - \\
\hline & 16 & 69 & - & - & - & - & - & - \\
\hline \multirow{3}{*}{$\begin{array}{l}\text { Doenças do sistema nervoso } \\
\text { Doenças do sistema osteomuscular e do } \\
\text { tecido conjuntivo } \\
\text { Doenças endócrinas, nutricionais e } \\
\text { metabólicas }\end{array}$} & 47 & 31 & 39 & - & - & - & - & - \\
\hline & 83 & 352 & 229 & 130 & 445 & - & - & - \\
\hline & 14 & 18 & 114 & 108 & 45 & - & - & - \\
\hline $\begin{array}{l}\text { Fatores que influenciam o estado de } \\
\text { saúde e o contato com os serviços de } \\
\text { saúde }\end{array}$ & 272 & 379 & 241 & 147 & 36 & 472 & 3660 & - \\
\hline \multirow{3}{*}{$\begin{array}{l}\text { Gravidez, parto e puerpério } \\
\text { Lesões, envenenamentos e algumas } \\
\text { outras consequências de causas } \\
\text { externas } \\
\text { Malformações congênitas, deformidades } \\
\text { e anomalias cromossômicas }\end{array}$} & 6 & 32 & 48 & 41 & - & 120 & 120 & - \\
\hline & 29 & 199 & 198 & 216 & 158 & - & - & - \\
\hline & 2 & - & 14 & - & - & - & - & - \\
\hline \multirow{2}{*}{$\begin{array}{l}\text { Neoplasmas (tumores) } \\
\text { Sintomas, sinais e achados anormais de } \\
\text { exames clínicos e de laboratório, não } \\
\text { classificados em outra parte }\end{array}$} & 12 & 29 & 118 & 226 & 737 & - & - & - \\
\hline & 77 & 114 & 15 & - & - & - & - & - \\
\hline \multirow{2}{*}{$\begin{array}{l}\text { Transtornos mentais e comportamentais } \\
\text { Outros Motivos de Falta (abono, nojo, } \\
\text { gala, sem CID-10) }\end{array}$} & 41 & 227 & 249 & 1716 & 983 & - & - & - \\
\hline & 2098 & 992 & 660 & 576 & 159 & 1522 & 180 & 1301 \\
\hline Total & 3132 & 3355 & 2334 & 3239 & 2955 & 2169 & 3960 & 1301 \\
\hline
\end{tabular}

Fonte: Elaborado pelo autor com base nos dados Ribeirão Preto, 2015.

Multiplicando 991 professores de Educação Básica II, atuantes em 2014, por 200 dias letivos, tem-se o total de 198.200 dias de aulas que teriam que ser ministrados para os alunos de 4 e 5 anos e de $1^{\circ}$ ao $5^{\circ}$ da Rede Municipal de Ribeirão Preto. Mas a Rede tem 22.445 dias de afastamento dos professores, ou seja, $11 \%$ a menos de 
aulas. Este fato gera duas possibilidades: ou os alunos ficam sem aulas ou a Secretaria de Educação aumenta os gastos para contratar professores substitutivos. As licenças saúde foram responsáveis por 14927 dias de licenças, ou seja mais de $66 \%$, do total de dias de afastamento concedidos. Estas licenças são responsáveis por apenas $33 \%$ dos afastamentos de 1 dia e as principais responsáveis pelos afastamentos de mais de 1 dia até 120 dias.

\subsection{Análise das ausências por Licença de Saúde}

As análises dos próximos dados foram feitas apenas com as informações sobre as faltas dos docentes por Motivo de Saúde, ou seja, o total de 2003 licenças. Lembrando que esse total não são os de dias sem aulas, mas sim de licenças por docentes.

As análises das faltas dos docentes afastados por doenças foram feitas de acordo com a Classificação Estatística Internacional de Doenças e Problemas Relacionados à Saúde. Decidiu-se agrupar os atestados dos docentes de acordo com os capítulos estabelecidos por esta Classificação, conhecida com a CID-10.

Dentre os 22 capítulos da divisão da CID-10, as doenças dos professores PEB Il da Rede Municipal de Educação de 2014 se encaixam em 18 capítulos (Quadro 2): 
Quadro 2 - Capítulos da CID-10, código e título dos capítulos

\begin{tabular}{|c|c|c|}
\hline Capítulo da CID-10 & Código dos Capítulos & Título dos capítulos \\
\hline Capítulo I & Códigos A00 - B99 & $\begin{array}{l}\text { Algumas doenças infecciosas e } \\
\text { parasitárias }\end{array}$ \\
\hline Capítulo II & Códigos C00 - D48 & Neoplasmas (tumores). \\
\hline Capítulo IV & Códigos E00 - E90 & $\begin{array}{l}\text { Doenças endócrinas, nutricionais e } \\
\text { metabólicas }\end{array}$ \\
\hline Capítulo V & Códigos F00 - F99 & $\begin{array}{l}\text { Transtornos mentais e } \\
\text { comportamentais }\end{array}$ \\
\hline Capítulo VI & Códigos G00 - G99 & Doenças do sistema nervoso. \\
\hline Capítulo VII & Códigos H00 - H59 & Doenças do olho e anexos. \\
\hline Capítulo VIII & Códigos H60 - H95 & $\begin{array}{l}\text { Doenças do ouvido e da apófise } \\
\text { mastoide. }\end{array}$ \\
\hline Capítulo IX & Códigos 100 - 199 & Doenças do aparelho circulatório \\
\hline Capítulo X & Códigos J00 - J99 & Doenças do aparelho respiratório \\
\hline Capítulo XI & Códigos K00 - K93 & Doenças do aparelho digestivo \\
\hline Capítulo XII & Códigos L00 - L99 & $\begin{array}{l}\text { Doenças da pele e do tecido } \\
\text { subcutâneo }\end{array}$ \\
\hline Capítulo XIII & Códigos M00 - M99 & $\begin{array}{c}\text { Doenças do sistema } \\
\text { osteomuscular e do tecido } \\
\text { conjuntivo }\end{array}$ \\
\hline Capítulo XIV & Códigos N00 - N99 & Doenças do aparelho geniturinário \\
\hline Capítulo XXI & Códigos Z00 - Z99 & $\begin{array}{l}\text { Fatores que influenciam o estado } \\
\text { de saúde e o contato com os } \\
\text { serviços de saúde. }\end{array}$ \\
\hline Capítulo XV & Códigos O00 - O99 & Gravidez, parto e puerpério \\
\hline Capítulo XVII & Códigos Q00 - Q99 & $\begin{array}{l}\text { Malformações congênitas, } \\
\text { deformidades e anomalias } \\
\text { cromossômicas. }\end{array}$ \\
\hline Capítulo XVIII & Códigos R00 - R99 & $\begin{array}{c}\text { Sintomas, sinais e achados } \\
\text { anormais de exames clínicos e de } \\
\text { laboratório, não classificados em } \\
\text { outra parte } \\
\end{array}$ \\
\hline Capítulo XIX & Códigos S00 - T98 & $\begin{array}{l}\text { Lesões, envenenamentos e } \\
\text { algumas outras consequências de } \\
\text { causas externas. }\end{array}$ \\
\hline
\end{tabular}

Fonte: OMS (2008). 
Ao agrupar os atestados de acordo com os capítulos que norteiam a CID - 10, encontra-se em primeiro lugar em número de atestados o capítulo XXI - Códigos Z00 - Z99 - Fatores que influenciam o estado de saúde e o contato com os serviços de saúde com 436 atestados (Gráfico 6), capítulo este que será explicado mais detalhado posteriormente.

Ainda detendo-se ao Gráfico 6, em segundo lugar, ficaram as doenças relacionadas ao aparelho respiratório - Capítulo X (Códigos J00 - J99) com 232 atestados.

Em terceiro lugar temos os atestados relacionados ao Capítulo XIII (Códigos M00 - M99) que dizem respeito às "Doenças do sistema osteomuscular e do tecido conjuntivo". E em quarto lugar, aparece o Capítulo V (Códigos F00 - F99), que diz respeito aos "Transtornos mentais e comportamentais", com 200 casos.

Outro dado observado no Gráfico 6, é o fato de apenas 23 professoras tirarem licença por "Gravidez, parto e puerpério" em 2014. Sendo que 16 licenças delas foram tiradas por docentes entre 30 a 39 anos e 7 licenças estão localizadas entre as professoras de $40-49$ anos. 
Gráfico 6 - Número faltas por agrupamento dos capítulos da CID-10

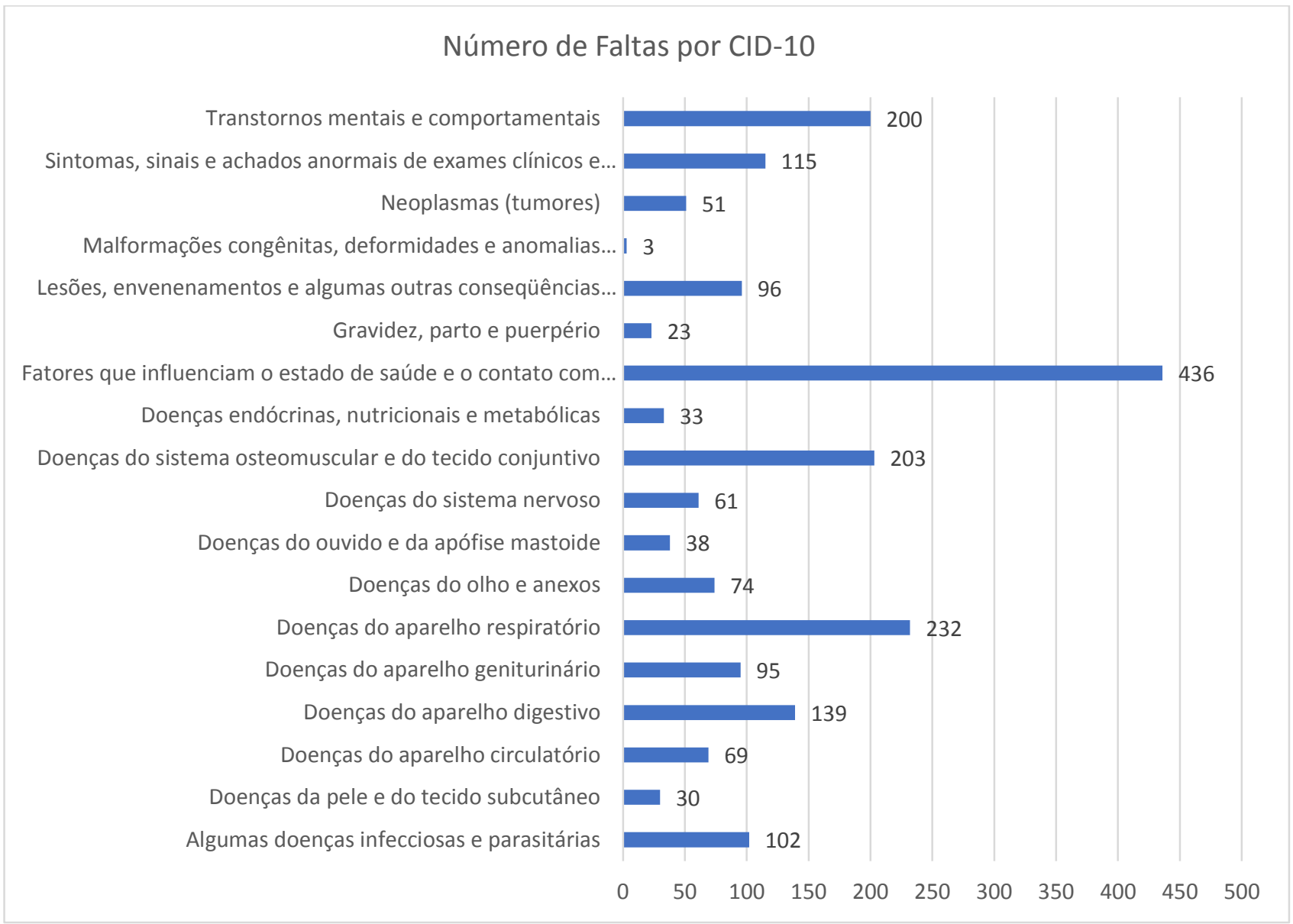

Fonte: Elaborado pelo autor com base nos dados Ribeirão Preto, 2015.

Como foi observado, dentre de todas as licenças de saúde, os afastamentos que pertencem o capítulo XXI - Códigos Z00 - Z99 - Fatores que influenciam o estado de saúde e o contato com os serviços de saúde - foi o que mais se destacou. Segundo a OMS (2008), os códigos de Z00 - Z98 são fornecidas para as ocasiões em que outras circunstâncias que não uma doença, um traumatismo ou uma causa externa classificáveis nas categorias A00 - Y89, são registradas como "diagnósticos" ou "problemas". Isto pode acontecer de dois modos principais:

(a) quando uma pessoa que não está doente consulta os serviços de saúde para algum propósito específico, tais como receber assistência ou serviço limitado para uma afecção atual, doar órgão ou tecido, receber imunização profilática ou discutir um problema que não é em si uma doença ou um traumatismo;

(b) quando alguma circunstância ou problema está presente e que influencia o estado de saúde da pessoa mas que não é em si uma doença ou traumatismo atual. Tais fatores podem ser obtidos durante inquéritos populacionais, quando a pessoa pode ou não estar atualmente doente, ou serem registrados como fator 
adicional a ser levado em conta quando a pessoa está recebendo cuidados para alguma doença ou traumatismo.

\section{Este capítulo contém os seguintes agrupamentos:}

Z00-Z13 Pessoas em contato com os serviços de saúde para exame e investigação

Z20-Z29 Pessoas com riscos potenciais à saúde relacionados com doenças transmissíveis

Z30-Z39 Pessoas em contato com os serviços de saúde em circunstâncias relacionadas com a reprodução

Z40-Z54 Pessoas em contato com os serviços de saúde para procedimentos e cuidados específicos

Z55-Z65 Pessoas com riscos potenciais à saúde relacionados com circunstâncias socioeconômicas e psicossociais

Z70-Z76 Pessoas em contato com os serviços de saúde em outras circunstâncias

Z80-Z99 Pessoas com riscos potenciais à saúde relacionados com história familiar e pessoal e algumas afecções que influenciam o estado de saúde. (OMS, 2008).

Para exemplificar os atestados pertencentes ao Capítulo XXI (Códigos Z00 Z99) - Fatores que influenciam o estado de saúde e o contato com os serviços de saúde -, pode-se citar os exames de forma geral, as vacinações, as reabilitações, a doação de sangue, os problemas relacionado à família, e outros

Todas as doenças, que foram encontradas nos atestados dos professores de PEB II no período de 2014, estão em uma tabela detalhada (Apêndice B) com nome dos Capítulos da CID-10, tipos de doença por Categoria da CID-10, número de casos doenças, porcentagem de casos doença, faltas por agrupamento da CID-10 e porcentagem de faltas por agrupamento.

Relacionando as porcentagens das faltas por capítulo da CID-10 com a idade dos docentes, obtém-se a Tabela 5, que apresenta um panorama de quais capítulos da CID-10 aparecem em maior porcentagem por faixa etária dividida entre 20-29 anos, 30-39, 40-49, 50-49 e mais de 60 anos.

A Tabela 5 analisa também as faltas por capítulo da CID-10 e idade, mas esta tabela representa o número de falta por capítulo da CID-10 e idade. Sendo assim, observa-se quantas faltas, atestados médicos, foram tirados por capítulo CID-10 em cada faixa etária. O que se destaca nesta tabela é o fato de que a faixa etária entre 40-49 anos é a que mais se ausentou por "Transtornos mentais e comportamentais" (83 atestados). Também chama atenção o fato da faixa etária entre 30-39 ser a que mais apresenta "Doenças do aparelho respiratório". 
Tabela 5 - Número de Faltas por capítulo da CID-10 e Idade

\begin{tabular}{|c|c|c|c|c|c|}
\hline \multirow[b]{2}{*}{ Capítulos da CID-10 } & \multicolumn{5}{|c|}{ Faixas de Idade } \\
\hline & $\begin{array}{l}20- \\
29\end{array}$ & $\begin{array}{l}30- \\
39\end{array}$ & $\begin{array}{r}40- \\
49\end{array}$ & $\begin{array}{l}50- \\
59\end{array}$ & $\begin{array}{l}\text { Mais } \\
\text { de } 60\end{array}$ \\
\hline Algumas doenças infecciosas e parasitárias & 5 & 52 & 30 & 12 & 3 \\
\hline Doenças da pele e do tecido subcutâneo & 3 & 11 & 9 & 4 & 3 \\
\hline Doenças do aparelho circulatório & 0 & 12 & 29 & 15 & 13 \\
\hline Doenças do aparelho digestivo & 5 & 50 & 48 & 22 & 14 \\
\hline Doenças do aparelho geniturinário & 1 & 32 & 46 & 14 & 2 \\
\hline Doenças do aparelho respiratório & 8 & 102 & 78 & 39 & 5 \\
\hline Doenças do olho e anexos & 3 & 28 & 20 & 10 & 13 \\
\hline Doenças do ouvido e da apófise mastoide & 0 & 18 & 11 & 6 & 3 \\
\hline Doenças do sistema nervoso & 1 & 26 & 21 & 11 & 2 \\
\hline Doenças do sistema osteomuscular e do tecido conjuntivo & 0 & 50 & 53 & 72 & 28 \\
\hline Doenças endócrinas, nutricionais e metabólicas & 1 & 9 & 14 & 7 & 2 \\
\hline $\begin{array}{l}\text { Fatores que influenciam o estado de saúde e o contato } \\
\text { com os serviços de saúde }\end{array}$ & 10 & 210 & 150 & 52 & 14 \\
\hline Gravidez, parto e puerpério & 0 & 16 & 7 & 0 & 0 \\
\hline $\begin{array}{l}\text { Lesões, envenenamentos e algumas outras } \\
\text { consequências de causas externas }\end{array}$ & 0 & 0 & 0 & 0 & 0 \\
\hline $\begin{array}{l}\text { Malformações congênitas, deformidades e anomalias } \\
\text { cromossômicas }\end{array}$ & 0 & 2 & 0 & 1 & 0 \\
\hline Neoplasmas (tumores) & 1 & 5 & 29 & 11 & 5 \\
\hline $\begin{array}{l}\text { Sintomas, sinais e achados anormais de exames clínicos e } \\
\text { de laboratório, não classificados em outra parte }\end{array}$ & 1 & 38 & 52 & 19 & 5 \\
\hline Transtornos mentais e comportamentais & 15 & 36 & 83 & 49 & 17 \\
\hline
\end{tabular}

Fonte: Elaborado pelo autor com base nos dados Ribeirão Preto, 2015

A Tabela 6, apresentada posteriormente, revela que os professores entre 20 29 anos são os que mais têm faltas por "transtornos mentais e comportamentais" $(27,27 \%)$. Este dado chama atenção por ser os docentes mais jovens e em começo de carreira que mais se ausentam por transtornos mentais, comprovando que fatores psicológicos e nível elevado de estresse podem acarretar em doenças. Cabe aqui um investimento na saúde mental dos docentes em começo de carreira. Nesta mesma faixa etária, em segundo lugar, tem-se os "fatores que influenciam o estado de saúde e o contato com os serviços de saúde" $(18,18 \%)$. Ainda sobre os professores mais jovens, observa-se que eles não se ausentaram numa por "doenças do sistema osteomuscular e do tecido conjuntivo".

Os professores entre 30 - 39 tiram mais licenças médicas por "fatores que influenciam o estado de saúde e o contato com os serviços de saúde" $(29,17 \%)$, seguida de "doenças do aparelho respiratório (14,17\%). 
A faixa etária entre 40 - 49 se ausenta também em primeiro lugar por "fatores que influenciam o estado de saúde e o contato com os serviços de saúde" $(20,83 \%)$, mas em segundo lugar as faltas são por transtornos mentais e comportamentais (Tabela 6).

Entre 50 - 59 os principais motivos das licenças são as "doenças do sistema osteomuscular e do tecido conjuntivo" (20,22\%), e "fatores que influenciam o estado de saúde e o contato com os serviços de saúde" (14,61\%) e acima de 60 anos os atestados de saúde são devido às "doenças do sistema osteomuscular e do tecido conjuntivo" (18,79\%) e às "lesões, envenenamentos e algumas outras consequências de causas externas" $(13,42 \%)$. Nestas duas faixas etária, onde se tem os professores mais velhos, observa-se uma porcentagem alta de "doenças do sistema osteomuscular e do tecido conjuntivo", seria necessário maior investigação para saber se essas doenças estão relacionadas a idade e traçar um plano para diminuir esse índice. Essas porcentagens comprovam que as situações variadas do cotidiano da sala de aula têm como resultado fatores relacionados diretamente ao corpo.

Ainda na Tabela 6, observa-se que os "transtornos mentais e comportamentais" ficam em terceiro lugar nas faixas etárias entre 40 a 49,50 a 59 e acima de 60 anos. 
Tabela 6 - Porcentagem de capítulos da CID-10 por faixa de idade

\section{Faixa de idade}

\begin{tabular}{|c|c|c|c|c|c|}
\hline Capítulos da CID-10 & $20-29$ & $30-39$ & $40-49$ & $50-59$ & $\begin{array}{l}\text { Mais } \\
\text { de } 60\end{array}$ \\
\hline Algumas doenças infecciosas e parasitárias & $9,09 \%$ & $7,22 \%$ & $4,17 \%$ & $3,37 \%$ & $2,01 \%$ \\
\hline Doenças da pele e do tecido subcutâneo & $5,45 \%$ & $1,53 \%$ & $1,25 \%$ & $1,12 \%$ & $2,01 \%$ \\
\hline Doenças do aparelho circulatório & $0,00 \%$ & $1,67 \%$ & $4,03 \%$ & $4,21 \%$ & $8,72 \%$ \\
\hline Doenças do aparelho digestivo & $9,09 \%$ & $6,94 \%$ & $6,67 \%$ & $6,18 \%$ & $9,40 \%$ \\
\hline Doenças do aparelho geniturinário & $1,82 \%$ & $4,44 \%$ & $6,39 \%$ & $3,93 \%$ & $1,34 \%$ \\
\hline Doenças do aparelho respiratório & $14,55 \%$ & $14,17 \%$ & $10,83 \%$ & $10,96 \%$ & $3,36 \%$ \\
\hline Doenças do olho e anexos & $5,45 \%$ & $3,89 \%$ & $2,78 \%$ & $2,81 \%$ & $8,72 \%$ \\
\hline Doenças do ouvido e da apófise mastoide & $0,00 \%$ & $2,50 \%$ & $1,53 \%$ & $1,69 \%$ & $2,01 \%$ \\
\hline $\begin{array}{l}\text { Doenças do sistema nervoso } \\
\text { Doenças do sistema osteomuscular e do tecido } \\
\text { conjuntivo }\end{array}$ & $1,82 \%$ & $3,61 \%$ & $2,92 \%$ & $3,09 \%$ & $1,34 \%$ \\
\hline $\begin{array}{l}\text { Doenças endócrinas, nutricionais e metabólicas } \\
\text { Fatores que influenciam o estado de saúde e o } \\
\text { contato com os serviços de saúde }\end{array}$ & $1,82 \%$ & $1,25 \%$ & $1,94 \%$ & $1,97 \%$ & $1,34 \%$ \\
\hline $\begin{array}{l}\text { Gravidez, parto e puerpério } \\
\text { Lesões, envenenamentos e algumas outras } \\
\text { consequências de causas externas } \\
\text { Malformações congênitas, deformidades e } \\
\text { anomalias cromossômicas }\end{array}$ & $1,82 \%$ & $3,19 \%$ & $5,56 \%$ & $3,37 \%$ & $13,42 \%$ \\
\hline $\begin{array}{l}\text { Neoplasmas (tumores) } \\
\text { Sintomas, sinais e achados anormais de exames } \\
\text { clínicos e de laboratório, não classificados em } \\
\text { outra parte }\end{array}$ & $1,82 \%$ & $0,69 \%$ & $4,03 \%$ & $3,09 \%$ & $3,36 \%$ \\
\hline Transtornos mentais e comportamentais & $27,27 \%$ & $5,00 \%$ & $11,53 \%$ & $13,76 \%$ & $11,41 \%$ \\
\hline
\end{tabular}

Fonte: Elaborado pelo autor com base nos dados Ribeirão Preto, 2015

O Gráfico 7 mostra o total de licenças médicas por gênero. Dos 2003 casos de absenteísmo por doença, apenas 35 Licenças Médicas foram dos professores do sexo masculino, enquanto 1968 ausências por motivo de saúde foram das docentes. Esse fato se dá porque os profissionais de Educação Infantil e Ensino Fundamental I são tradicionalmente mulheres. 
Gráfico 7 - Total de licenças médicas por gênero

Total de lincenças médicas por gênero.

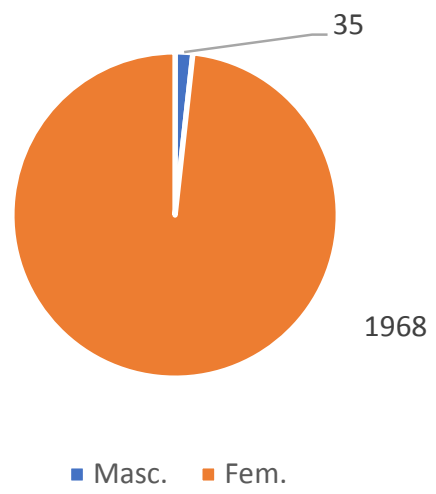

Fonte: Elaborado pelo autor com base nos dados Ribeirão Preto, 2015.

Associando-se os capítulos da CID-10 por gênero, nota-se que há diferença entre as doenças que acometem as mulheres e as que levam os homens a se afastarem de suas atividades profissionais.

O Gráfico 8 permite analisar o percentual dos 16 grupos de doenças que afetam as mulheres que lecionaram como PEB II na Rede Municipal de Educação de Ribeirão Preto:

- "Fatores que influenciam o estado de saúde e o contato com os serviços de saúde" $(22,04 \%)$;

- "Doenças do aparelho respiratório" (11,60\%);

- "Transtornos mentais e comportamentais" $(10,08 \%)$;

- "Doenças do sistema osteomuscular e do tecido conjuntivo" $(10,03 \%)$;

- "Doenças do aparelho digestivo" (6,82\%);

- "Sintomas, sinais e achados anormais de exames clínicos e de laboratório, não classificados em outra parte" (5,75\%);

- "Algumas doenças infecciosas e parasitárias" (4,89\%);

- "Doenças do aparelho geniturinário" (4,83\%)

- "Lesões, envenenamentos e algumas outras consequências de causas externas" $(4,73 \%)$;

- "Doenças do olho e anexos" (3,77\%);

- "Doenças do aparelho circulatório" (3,51\%); 
- "Doenças do sistema nervoso" (3,00\%);

- "Neoplasmas (tumores)" (2,60\%);

- "Doenças do ouvido e da apófise mastoide" $(1,88 \%)$;

- "Doenças endócrinas, nutricionais e metabólicas" (1,68\%);

- "Doenças da pele e do tecido subcutâneo" (1,48\%);

- "Gravidez, parto e puerpério" (1,17\%).

Pode-se aferir que somente as mulheres se afastam por "Doenças do olho e anexos", "Doenças do aparelho circulatório", "Doenças do aparelho geniturinário", "Neoplasmas (tumores)" e "Doenças endócrinas, nutricionais e metabólicas", como mostra o Gráfico 8.

Nota-se que, no ano de 2014, dos 724 atestados femininos, apenas 23 mulheres tiraram atestado por "Gravidez, parto e puerpério" $(1,17 \%)$. 


\section{Gráfico 8 - Percentual de Faltas por capítulo da CID-10 e gênero}

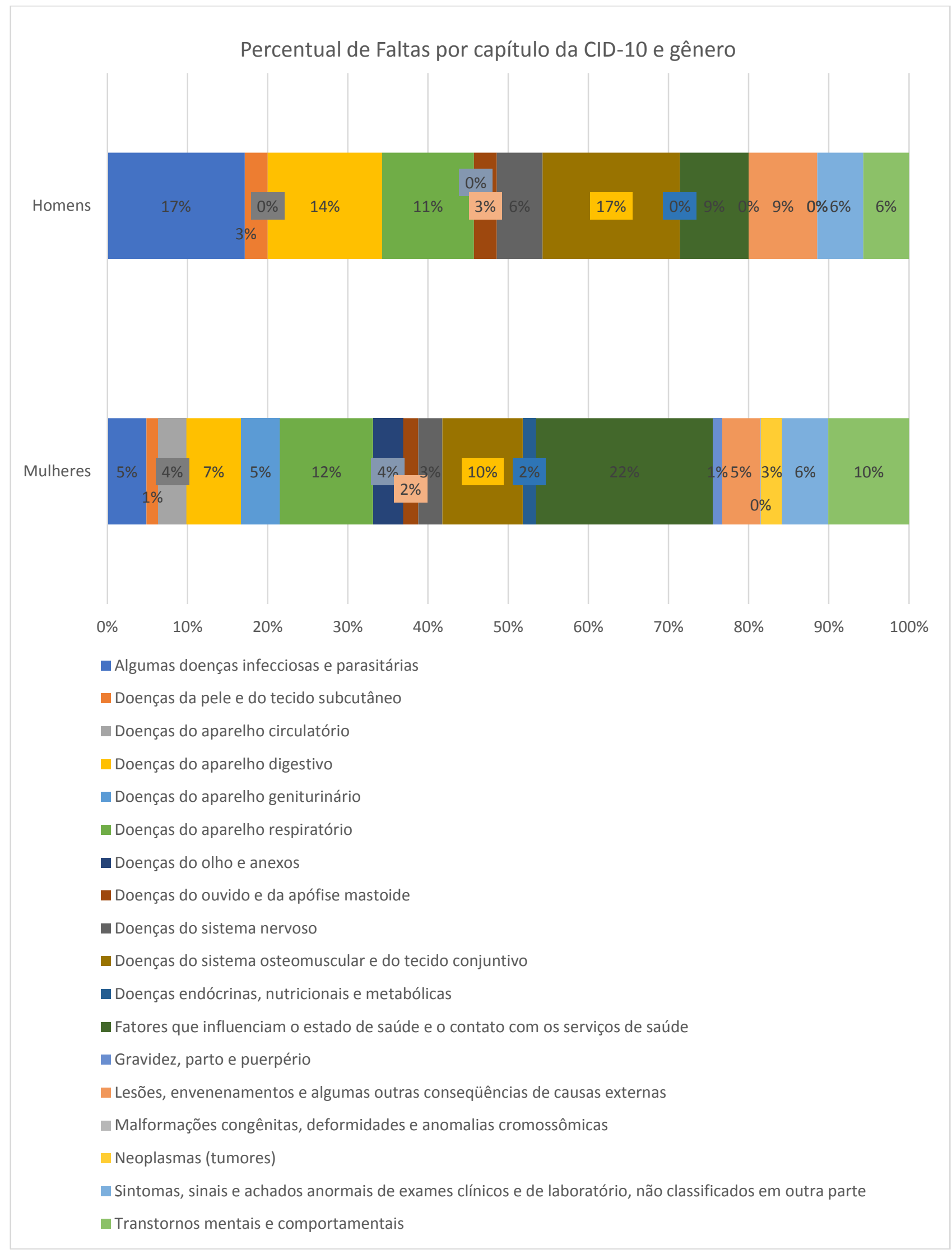

Fonte: Elaborado pelo autor com base nos dados Ribeirão Preto, 2015. 
As doenças que levaram o grupo de homens, que atuaram como PEB II, a se afastarem da prática da docência, se encaixam em 11 capítulos da CID-10 (Gráfico 8):

- "Algumas doenças infecciosas e parasitárias" (17,14\%);

- "Doenças do sistema osteomuscular e do tecido conjuntivo" (17,14\%);

- "Doenças do aparelho digestivo" (14,29\%);

- "Doenças do aparelho respiratório" $(11,43 \%)$;

- "Lesões, envenenamentos e algumas outras consequências de causas externas" $(8,57 \%)$

- "Fatores que influenciam o estado de saúde e o contato com os serviços de saúde" (8,57\%);

- "Transtornos mentais e comportamentais" $(5,71 \%)$;

- "Sintomas, sinais e achados anormais de exames clínicos e de laboratório, não classificados em outra parte" $(5,71 \%)$;

- "Doenças do sistema nervoso" (5,71\%);

- "Doenças da pele e do tecido subcutâneo" (2,68\%);

- "Doenças do ouvido e da apófise mastoide" (2,68\%).

Ao analisar os capítulos da CID-10 por número de atestados de Licenças para Tratamento de Saúde, ficou destacado que as licenças se concentram mais nos afastamento de 1 dia, de até 10 dias e até 15 (Tabela 10). O capítulo da CID-10 "Fatores que influenciam o estado de saúde e o contato com os serviços de saúde" é o que mais apresenta afastamento de 1 dia (272 atestados). Em LTS de até 10 dias, o que mais aparece é o capítulo "Doenças do aparelho respiratório" (104 atestados). Esse mesmo capítulo "Doenças do aparelho respiratório" também apresenta um número alto de atestados de 1 dia (125 atestados).

O maior motivo de Licenças para Tratamento de Saúde de 30 dias foi devido aos "Transtornos mentais e comportamentais" com 61 casos.

Os professores de Educação Básica II em 2014 tiveram um total de 2003 atestados para tratamento de saúde. Observa-se que as licenças de 1 dia, de até 10 dias e até 15 dias são as que englobam a maioria dos atestados. Já as licenças de 30 dias ou mais, concentram menor número de atestado (Tabela 7). 
Tabela 7 - Capítulos da CID-10 por número de atestados de LTS/dias

\begin{tabular}{|c|c|c|c|c|c|c|c|}
\hline \multirow[b]{2}{*}{ Capítulos da CID-10 } & \multicolumn{7}{|c|}{ Número de Atestados de LTS/dias } \\
\hline & $\begin{array}{l}\text { LTS } \\
1 \text { dia }\end{array}$ & $\begin{array}{l}\text { LTS } \\
\text { até } 10 \\
\text { dias }\end{array}$ & $\begin{array}{l}\text { LTS } \\
\text { até } 15 \\
\text { dias }\end{array}$ & $\begin{array}{c}\text { LTS } \\
\text { até } 30 \\
\text { dias }\end{array}$ & $\begin{array}{c}\text { LTS } \\
\text { até } 45 \\
\text { dias }\end{array}$ & $\begin{array}{c}\text { LTS } \\
\text { até } 60 \\
\text { dias }\end{array}$ & $\begin{array}{l}\text { LTS } \\
\text { até } \\
120 \\
\text { dias }\end{array}$ \\
\hline $\begin{array}{l}\text { Algumas doenças } \\
\text { infecciosas e parasitárias }\end{array}$ & 59 & 43 & - & - & - & - & - \\
\hline $\begin{array}{l}\text { Doenças da pele e do tecido } \\
\text { subcutâneo }\end{array}$ & 22 & 6 & 2 & - & - & - & - \\
\hline $\begin{array}{l}\text { Doenças do aparelho } \\
\text { circulatório }\end{array}$ & 31 & 22 & 7 & 2 & 7 & - & - \\
\hline $\begin{array}{l}\text { Doenças do aparelho } \\
\text { digestivo }\end{array}$ & 96 & 30 & 11 & - & 1 & 1 & - \\
\hline $\begin{array}{l}\text { Doenças do aparelho } \\
\text { geniturinário }\end{array}$ & 69 & 19 & 5 & 1 & 1 & - & - \\
\hline $\begin{array}{l}\text { Doenças do aparelho } \\
\text { respiratório }\end{array}$ & 125 & 104 & 3 & - & - & - & - \\
\hline Doenças do olho e anexos & 33 & 40 & 1 & - & - & - & - \\
\hline $\begin{array}{l}\text { Doenças do ouvido e da } \\
\text { apófise mastoide }\end{array}$ & 16 & 22 & - & - & - & - & - \\
\hline $\begin{array}{l}\text { Doenças do sistema } \\
\text { nervoso } \\
\text { Doenças do sistema }\end{array}$ & 47 & 11 & 3 & - & - & - & - \\
\hline $\begin{array}{l}\text { osteomuscular e do tecido } \\
\text { conjuntivo }\end{array}$ & 83 & 87 & 16 & 6 & 11 & - & - \\
\hline $\begin{array}{l}\text { Doenças endócrinas, } \\
\text { nutricionais e metabólicas }\end{array}$ & 14 & 5 & 8 & 5 & 1 & - & - \\
\hline $\begin{array}{l}\text { Fatores que influenciam o } \\
\text { estado de saúde e o contato } \\
\text { com os serviços de saúde }\end{array}$ & 272 & 99 & 17 & 5 & 1 & 8 & 34 \\
\hline $\begin{array}{l}\text { Gravidez, parto e puerpério } \\
\text { Lesões, envenenamentos e }\end{array}$ & 6 & 8 & 4 & 2 & - & 2 & 1 \\
\hline $\begin{array}{l}\text { algumas outras } \\
\text { consequências de causas } \\
\text { externas }\end{array}$ & 29 & 40 & 14 & 9 & 4 & - & - \\
\hline $\begin{array}{l}\text { Malformações congênitas, } \\
\text { deformidades e anomalias } \\
\text { cromossômicas }\end{array}$ & 2 & - & 1 & - & - & - & - \\
\hline $\begin{array}{l}\text { Neoplasmas (tumores) } \\
\text { Sintomas, sinais e achados } \\
\text { anormais de exames }\end{array}$ & 12 & 6 & 8 & 8 & 17 & - & - \\
\hline $\begin{array}{l}\text { clínicos e de laboratório, } \\
\text { não classificados em outra } \\
\text { parte }\end{array}$ & 77 & 37 & 1 & - & - & - & - \\
\hline $\begin{array}{l}\text { Transtornos mentais e } \\
\text { comportamentais }\end{array}$ & 41 & 54 & 18 & 61 & 26 & - & - \\
\hline Total & 1034 & 633 & 119 & 99 & 69 & 11 & 35 \\
\hline
\end{tabular}

Fonte: Elaborado pelo autor com base nos dados Ribeirão Preto, 2015. 
Dos 748 professores, atuantes como PEB II, que se ausentaram, 663 tiraram licença de 1 dia, 322 professores se afastaram por um período de até 10 dias, 83 docentes tiveram suas atividades afastadas até 15 dias, 38 professores ficaram afastados por até 30 dias, 30 tiraram licença de até 45 dias, 10 docentes se ausentaram por até 60 dias e 34 receberam licença de até 120 dias (tabela 8).

Somando-se o número de dias perdidos por absenteísmo relacionado à Licença de Tratamento de Saúde - LTS, temos o total de 14.957 dias de ausência do docente efetivo nas salas de PEB II.

Tabela 8 - Resultados das Licença para Tratamento de Saúde (LTS)

\begin{tabular}{|c|c|c|c|c|c|}
\hline PEB II & & & & & \\
\hline Dias de LTS & $\begin{array}{c}\text { Número } \\
\text { professores }\end{array}$ & $\begin{array}{c}\text { Número } \\
\text { atestados }\end{array}$ & $\begin{array}{c}\text { Média de } \\
\text { atestado/ } \\
\text { professores }\end{array}$ & $\begin{array}{l}\text { Número } \\
\text { dias } \\
\text { perdidos }\end{array}$ & $\begin{array}{c}\text { Média de } \\
\text { dias/ } \\
\text { professores }\end{array}$ \\
\hline LTS 1 dia & 366 & 1.035 & 2,83 & 1.035 & 2,83 \\
\hline $\begin{array}{l}\text { LTS até } 10 \\
\text { dias }\end{array}$ & 322 & 635 & 1,97 & 2.372 & 7,37 \\
\hline $\begin{array}{c}\text { LTS até } 15 \\
\text { dias }\end{array}$ & 83 & 119 & 1,43 & 1.674 & 20,17 \\
\hline $\begin{array}{c}\text { LTS até } 30 \\
\text { dias }\end{array}$ & 38 & 99 & 2,61 & 2.663 & 70,08 \\
\hline $\begin{array}{c}\text { LTS até } 45 \\
\text { dias }\end{array}$ & 30 & 69 & 2,30 & 2.796 & 93,20 \\
\hline $\begin{array}{l}\text { LTS até } 60 \\
\text { dias }\end{array}$ & 10 & 11 & 1,10 & 647 & 64,70 \\
\hline $\begin{array}{l}\text { LTS até } 120 \\
\text { dias }\end{array}$ & 34 & 35 & 1,03 & 3.780 & 111,18 \\
\hline
\end{tabular}

Fonte: Elaborado pelo autor com base nos dados Ribeirão Preto, 2015.

Com o alto índice de absenteísmo e o grande número de dias letivos sem os professores efetivos das turmas de Educação Básica II, é necessário, por parte da Secretaria da Educação, fazer a reposição dos docentes e isto acarreta custos extras à Secretaria. Há ainda a possibilidade das escolas que tem alto índice de absenteísmo ficarem sem reposição de professores. Este fato pode baixar a qualidade da educação, afetando diretamente o discente. 


\subsection{Análise do Absenteísmo nas Escolas Municipais de PEB II}

Para a realização da análise do absenteísmo nas Escolas Municipais de Ribeirão Preto, foram retirados os nomes das mesmas para que não fossem reconhecidas na hora das análises. $\mathrm{E}$ as escolas foram agrupadas por região. Em 2014, 30 escolas estavam localizadas na região Norte da cidade, 26 na região Leste, 16 na região Oeste e apenas 3 escolas na região Sul como se observa no Gráfico 9.

Gráfico 9 - Porcentagem das escolas por região

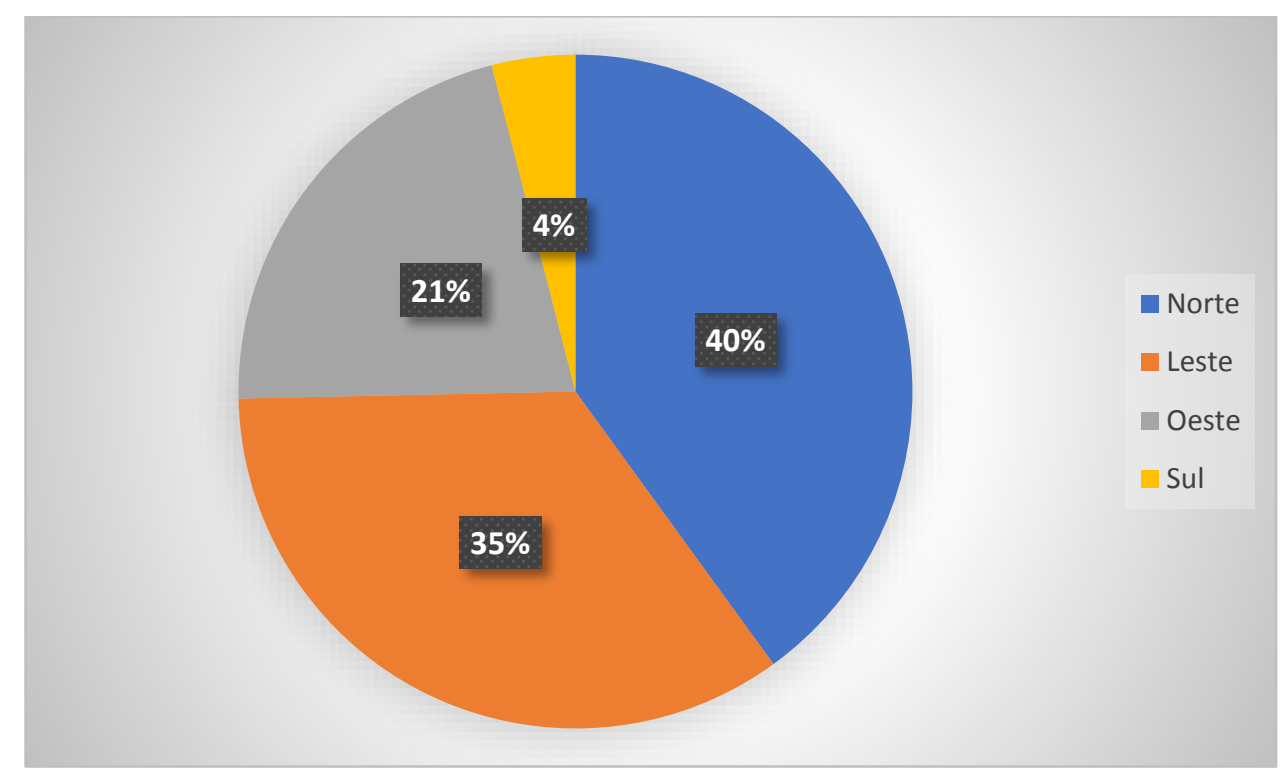

Fonte: Elaborado pelo autor com base nos dados INEP, 2015.

A Tabela 9 apresenta os dados sobre o absenteísmo nas escolas da Rede Municipal de Ribeirão Preto, a mesma engloba as escolas e suas regiões, bem como os dados sobre o absenteísmo (Total de Licenças, Faltas Abonadas e Licença Prêmio, Faltas para Licença de Tratamento de Saúde - LTS, Faltas Nojo, Gala e Gestante).

Observa-se na Tabela 9, além das 75 escolas que apresentam absenteísmo docente, o Departamento de Educação com 18 faltas por LTS. Esse fato ocorreu, porque alguns professores de Educação Básica II, em 2014, estavam realizando suas funções no próprio Departamento de Educação. Apesar de serem professores Educação Básica II estavam comissionados na gestão escolar em cargos exclusivos para professores. Nos dados disponibilizados pela Secretaria de Educação, as faltas destes docentes não estavam vinculadas ao nome da escola onde são professores titulares, mas onde estavam efetivamente trabalhando, no caso o Departamento de Educação. 
Tabela 9 - Escolas por número de faltas por motivos das licenças

\begin{tabular}{|c|c|c|c|c|c|c|c|c|c|}
\hline Escola & Região & $\begin{array}{c}\text { Falta } \\
\text { Abonada }\end{array}$ & $\begin{array}{l}\text { Falta por } \\
\text { Motivo de } \\
\text { Saúde }\end{array}$ & Outros & $\begin{array}{c}\text { Licença } \\
\text { Gala }\end{array}$ & $\begin{array}{c}\text { Prorrogação } \\
\text { Licença } \\
\text { Gestante }\end{array}$ & $\begin{array}{c}\text { Licença } \\
\text { Nojo }\end{array}$ & $\begin{array}{l}\text { Licença } \\
\text { Prêmio }\end{array}$ & $\begin{array}{l}\text { Total de } \\
\text { Licenças }\end{array}$ \\
\hline Escola 1 & Norte & 1 & 0 & 0 & 0 & 0 & 0 & 0 & 1 \\
\hline Escola 2 & Norte & 3 & 1 & 1 & 1 & 0 & 0 & 0 & 6 \\
\hline Escola 3 & Leste & 2 & 3 & 0 & 0 & 1 & 0 & 0 & 6 \\
\hline Escola 4 & Leste & 62 & 62 & 1 & 1 & 2 & 1 & 5 & 134 \\
\hline Escola 5 & Norte & 94 & 88 & 0 & 0 & 3 & 3 & 2 & 190 \\
\hline Escola 6 & Oeste & 16 & 66 & 1 & 1 & 1 & 1 & 1 & 87 \\
\hline Escola 7 & & 0 & 18 & 0 & 0 & 0 & 0 & 0 & 18 \\
\hline Escola 8 & Leste & 27 & 26 & 0 & 0 & 0 & 0 & 0 & 53 \\
\hline Escola 9 & Leste & 27 & 45 & 0 & 1 & 0 & 0 & 8 & 81 \\
\hline Escola 10 & Sul & 30 & 12 & 0 & 0 & 1 & 1 & 4 & 48 \\
\hline Escola 11 & Oeste & 17 & 21 & 0 & 0 & 0 & 0 & 0 & 38 \\
\hline Escola 12 & Oeste & 26 & 33 & 1 & 0 & 0 & 1 & 0 & 61 \\
\hline Escola 13 & Oeste & 8 & 11 & 0 & 0 & 0 & 0 & 0 & 19 \\
\hline Escola 14 & Oeste & 33 & 52 & 0 & 0 & 0 & 1 & 1 & 87 \\
\hline Escola 15 & Sul & 24 & 30 & 2 & 0 & 0 & 0 & 1 & 57 \\
\hline Escola 16 & Norte & 23 & 18 & 0 & 0 & 0 & 0 & 1 & 42 \\
\hline Escola 17 & Norte & 48 & 52 & 0 & 0 & 0 & 1 & 3 & 104 \\
\hline Escola 18 & Norte & 0 & 10 & 0 & 0 & 0 & 0 & 1 & 11 \\
\hline Escola 19 & Norte & 39 & 35 & 1 & 0 & 0 & 1 & 2 & 78 \\
\hline Escola 20 & Norte & 39 & 27 & 2 & 1 & 1 & 3 & 2 & 75 \\
\hline Escola 21 & Leste & 12 & 10 & 0 & 0 & 0 & 1 & 0 & 23 \\
\hline Escola 22 & Norte & 3 & 3 & 0 & 0 & 0 & 0 & 2 & 8 \\
\hline Escola 23 & Leste & 24 & 8 & 0 & 0 & 0 & 0 & 6 & 38 \\
\hline Escola 24 & Leste & 17 & 9 & 0 & 0 & 0 & 0 & 0 & 26 \\
\hline Escola 25 & Norte & 5 & 2 & 0 & 1 & 0 & 0 & 0 & 8 \\
\hline Escola 26 & Oeste & 50 & 22 & 0 & 0 & 0 & 0 & 7 & 79 \\
\hline Escola 27 & Sul & 35 & 18 & 0 & 0 & 0 & 0 & 2 & 55 \\
\hline Escola 28 & Oeste & 28 & 16 & 1 & 1 & 1 & 0 & 4 & 51 \\
\hline Escola 29 & Oeste & 42 & 26 & 0 & 0 & 0 & 0 & 9 & 77 \\
\hline Escola 30 & Leste & 7 & 10 & 0 & 0 & 0 & 0 & 0 & 17 \\
\hline Escola 31 & Norte & 21 & 5 & 0 & 0 & 0 & 1 & 1 & 28 \\
\hline Escola 32 & Norte & 31 & 39 & 0 & 0 & 1 & 3 & 0 & 74 \\
\hline Escola 33 & Norte & 54 & 46 & 0 & 0 & 0 & 1 & 6 & 107 \\
\hline Escola 34 & Oeste & 71 & 53 & 0 & 1 & 1 & 2 & 0 & 128 \\
\hline Escola 35 & Leste & 38 & 32 & 1 & 0 & 0 & 0 & 2 & 73 \\
\hline Escola 36 & Norte & 33 & 4 & 0 & 0 & 0 & 0 & 1 & 38 \\
\hline Escola 37 & Norte & 26 & 41 & 1 & 1 & 0 & 0 & 0 & 69 \\
\hline Escola 38 & Leste & 23 & 29 & 0 & 2 & 0 & 1 & 0 & 55 \\
\hline Escola 39 & Norte & 33 & 53 & 0 & 1 & 0 & 2 & 0 & 89 \\
\hline Escola 40 & Leste & 33 & 13 & 0 & 0 & 0 & 0 & 1 & 47 \\
\hline Escola 41 & Leste & 33 & 19 & 0 & 0 & 0 & 0 & 0 & 52 \\
\hline Escola 42 & Leste & 23 & 40 & 1 & 1 & 0 & 1 & 0 & 66 \\
\hline Escola 43 & Norte & 33 & 24 & 0 & 0 & 0 & 0 & 3 & 60 \\
\hline Escola 44 & Leste & 24 & 15 & 0 & 0 & 0 & 1 & 0 & 40 \\
\hline Escola 45 & Norte & 24 & 26 & 0 & 0 & 0 & 0 & 2 & 52 \\
\hline Escola 46 & Norte & 1 & 20 & 0 & 1 & 0 & 0 & 0 & 22 \\
\hline
\end{tabular}




\begin{tabular}{|c|c|c|c|c|c|c|c|c|c|}
\hline Escola & Região & $\begin{array}{c}\text { Falta } \\
\text { Abonada }\end{array}$ & $\begin{array}{c}\text { Faltas } \\
\text { por } \\
\text { Motivos } \\
\text { de Saúde }\end{array}$ & Outros & $\begin{array}{l}\text { Licença } \\
\text { Gala }\end{array}$ & $\begin{array}{c}\text { Prorrogação } \\
\text { Licença } \\
\text { Gestante }\end{array}$ & $\begin{array}{c}\text { Licença } \\
\text { Nojo }\end{array}$ & $\begin{array}{l}\text { Licença } \\
\text { Prêmio }\end{array}$ & Total \\
\hline Escola 47 & Leste & 36 & 29 & 0 & 0 & 0 & 0 & 1 & 66 \\
\hline Escola 48 & Leste & 9 & 14 & 0 & 0 & 0 & 0 & 0 & 23 \\
\hline Escola 49 & Oeste & 38 & 20 & 0 & 0 & 1 & 2 & 3 & 64 \\
\hline Escola 50 & Norte & 27 & 39 & 1 & 0 & 0 & 1 & 0 & 68 \\
\hline Escola 51 & Norte & 6 & 25 & 0 & 0 & 0 & 0 & 0 & 31 \\
\hline Escola 52 & Oeste & 25 & 15 & 0 & 0 & 1 & 0 & 1 & 42 \\
\hline Escola 53 & Norte & 24 & 51 & 0 & 0 & 0 & 2 & 1 & 78 \\
\hline Escola 54 & Leste & 42 & 26 & 1 & 0 & 0 & 4 & 3 & 76 \\
\hline Escola 55 & Leste & 19 & 11 & 0 & 0 & 0 & 0 & 0 & 30 \\
\hline Escola 56 & Norte & 37 & 50 & 0 & 0 & 1 & 1 & 2 & 91 \\
\hline Escola 57 & Norte & 20 & 17 & 0 & 0 & 0 & 1 & 0 & 38 \\
\hline Escola 58 & Norte & 57 & 75 & 1 & 0 & 1 & 1 & 5 & 140 \\
\hline Escola 59 & Oeste & 42 & 37 & 0 & 0 & 0 & 1 & 4 & 84 \\
\hline Escola 60 & Leste & 11 & 25 & 0 & 0 & 1 & 3 & 0 & 40 \\
\hline Escola 61 & Oeste & 12 & 5 & 0 & 0 & 0 & 0 & 0 & 17 \\
\hline Escola 62 & Leste & 32 & 66 & 0 & 0 & 2 & 0 & 0 & 100 \\
\hline Escola 63 & Leste & 46 & 20 & 0 & 0 & 0 & 0 & 1 & 67 \\
\hline Escola 64 & Leste & 17 & 23 & 0 & 0 & 0 & 1 & 0 & 41 \\
\hline Escola 65 & Norte & 38 & 19 & 0 & 0 & 0 & 0 & 4 & 61 \\
\hline Escola 66 & Leste & 7 & 6 & 0 & 0 & 0 & 1 & 0 & 14 \\
\hline Escola 67 & Leste & 40 & 37 & 0 & 0 & 0 & 2 & 0 & 79 \\
\hline Escola 68 & Norte & 21 & 22 & 0 & 0 & 0 & 0 & 1 & 44 \\
\hline Escola 69 & Leste & 49 & 50 & 0 & 0 & 1 & 0 & 0 & 100 \\
\hline Escola 70 & Norte & 24 & 14 & 0 & 1 & 2 & 0 & 1 & 42 \\
\hline Escola 71 & Oeste & 2 & 1 & 0 & 0 & 0 & 0 & 0 & 3 \\
\hline Escola 72 & Oeste & 17 & 21 & 0 & 1 & 2 & 1 & 0 & 42 \\
\hline Escola 73 & Norte & 35 & 20 & 1 & 1 & 0 & 0 & 3 & 60 \\
\hline Escola 74 & Norte & 49 & 43 & 4 & 0 & 2 & 1 & 1 & 100 \\
\hline Escola 75 & Leste & 40 & 11 & 0 & 0 & 0 & 1 & 1 & 53 \\
\hline Escola 76 & Oeste & 30 & 18 & 0 & 0 & 0 & 0 & 3 & 51 \\
\hline
\end{tabular}

Fonte: Elaborado pelo autor com base nos dados Ribeirão Preto, 2015.

A Tabela 10 apresenta o número total de escolas por região com os respectivos dados sobre o total absenteísmo, também por regiões. Nota-se que a região Norte, que engloba $40 \%$ das escolas, é a que mais apresenta total de licenças (vários causas) e licenças saúde. Foram concedidas um total de 869 licenças saúde nas escolas da região (44\% do total), vindo a seguir as regiões Leste (com 35\% das escolas e 639 licenças saúde - 32\% do total), Oeste (com 21\% das escolas e 417 licenças saúde também $21 \%$ do total) e Sul (4\% das escolas e 60 licenças saúde concedidas, $3 \%$ do total). 
Tabela 10 - Total de escolas por região e dados do absenteísmo

\begin{tabular}{cccccccccc}
\hline & Número & \multicolumn{8}{c}{ Número total de licenças } \\
\cline { 2 - 10 } Região & $\begin{array}{c}\text { de } \\
\text { escolas }\end{array}$ & $\begin{array}{c}\text { Falta } \\
\text { Abonadacenças } \\
\text { por }\end{array}$ & $\begin{array}{c}\text { Licença } \\
\text { Saúde }\end{array}$ & $\begin{array}{c}\text { Prorrogação } \\
\text { Oicença } \\
\text { Outros }\end{array}$ & $\begin{array}{c}\text { Lala } \\
\text { Gestante }\end{array}$ & $\begin{array}{c}\text { Licença } \\
\text { Nojo }\end{array}$ & $\begin{array}{c}\text { Licença } \\
\text { Prêmio }\end{array}$ & $\begin{array}{c}\text { Total de } \\
\text { Licenças }\end{array}$ \\
\hline Norte & 30 & 849 & 869 & 12 & 8 & 11 & 22 & 44 & 1815 \\
Leste & 26 & 700 & 639 & 4 & 5 & 7 & 17 & 28 & 1400 \\
Oeste & 16 & 457 & 417 & 3 & 4 & 7 & 9 & 33 & 930 \\
Sul & 3 & 89 & 60 & 2 & 0 & 1 & 1 & 7 & 160
\end{tabular}

Fonte: Elaborado pelo autor com base nos dados Ribeirão Preto, 2015.

A partir dos dados da tabela acima, tem-se também o número médio de licenças concedidas por Motivo de Saúde por escolas nas regiões: a região Norte teve uma média de 28,97 licenças por escola frente à região Leste com 24,58; a região Oeste com 26,06 e região Sul com 20,00 (Gráfico 10). Ou seja, a região Norte de Ribeirão tem um maior número de licenças concedidas, pois existem mais escolas nesta região e também porque se concedem, em média, mais licenças saúde por escola desta região.

Gráfico 10 - Número médio de licenças por motivo de saúde por escolas nas regiões de Ribeirão Preto

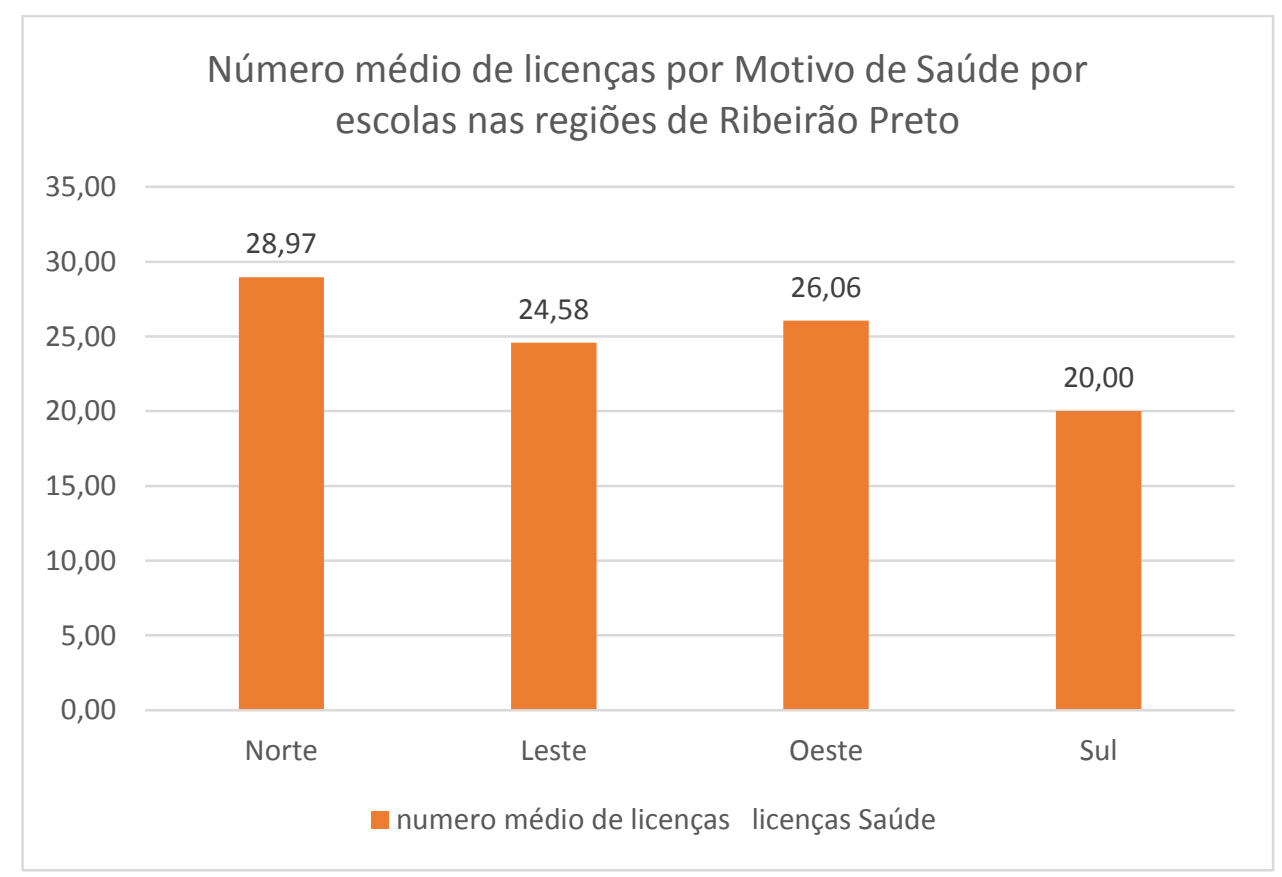

Fonte: Elaborado pelo autor com base nos dados Ribeirão Preto, 2015. 
Somando todos os motivos das ausências dos docentes em cada escola, observa-se as regiões em que se encontram as instituições de ensino de Educação Básica II com o maior número de absenteísmo (Gráfico 11): em primeiro e segundo lugares tem-se a Escola 5 e a Escola 58 situadas na região norte; em terceiro lugar tem-se a Escola 4 localizada na região leste; em quarto lugar a Escola 34, região oeste e em quinto lugar a Escola 33 também na região norte. Desta forma, novamente, percebe-se que as escolas municipais da região norte da cidade de Ribeirão Preto são as que mais apresentam absenteísmo docente.

Gráfico 11 - Números de faltas por motivos das licenças e escola

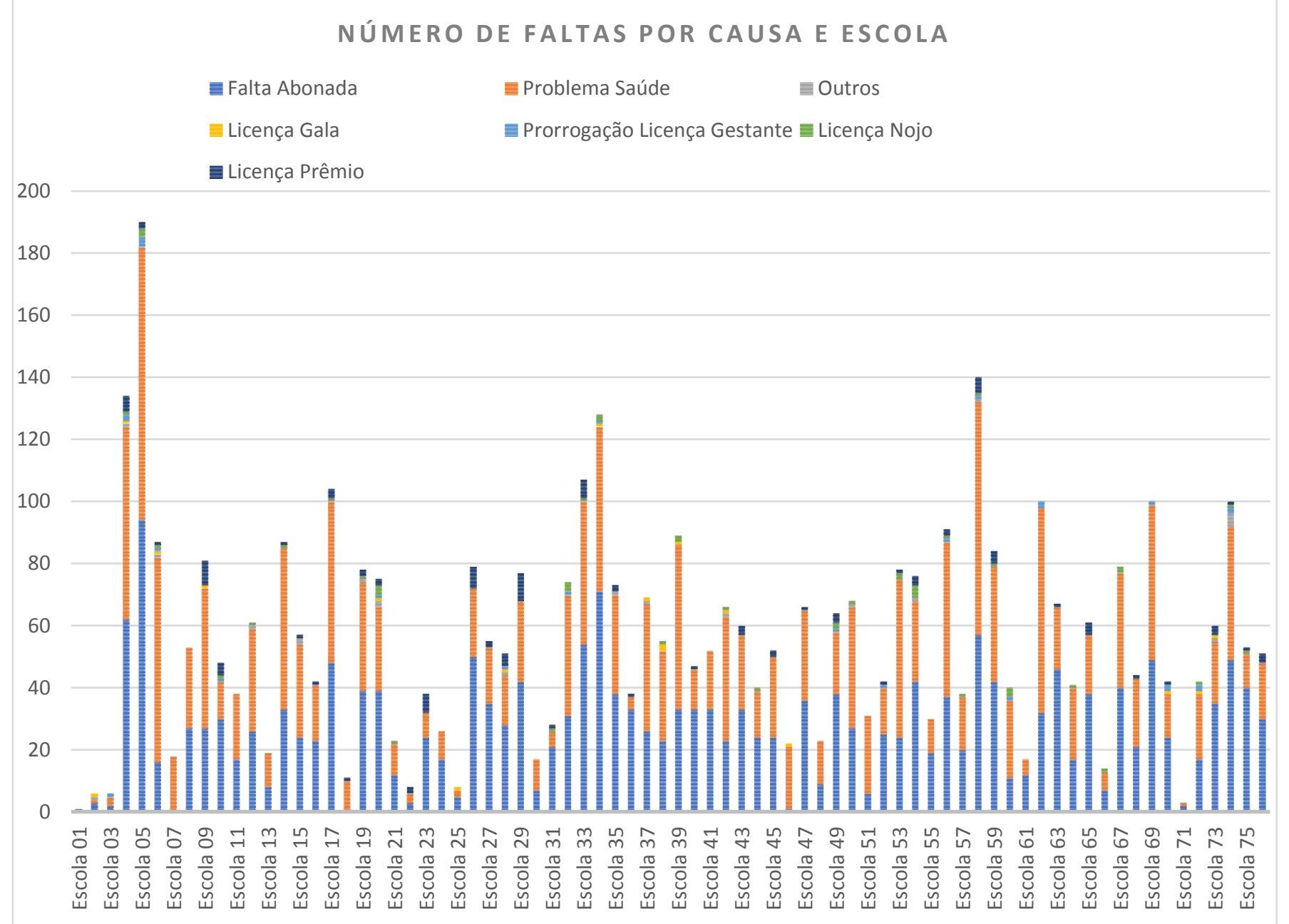

Fonte: Elaborado pelo autor com base nos dados Ribeirão Preto, 2015.

Em oposição às escolas que tiveram muito absenteísmo, existem escolas com poucas faltas. A Escola 1 situada na região norte teve apenas uma falta abonada. A 
Escola 71 localizada na região oeste teve apenas 3 faltas (2 abonadas e uma LTS). A Escola 2, região oeste, e a Escola 3 na região leste tiveram 6 faltas cada uma. As Escolas 22 e 25 ambas na região norte ficaram empatadas com 8 faltas.

O Gráfico 12 mostra as doenças que aparecem em cada escola. Por exemplo, o capítulo "Doenças do aparelho respiratório" aparece em três escolas das cinco que mais tiveram faltas por doenças: Escola 6 situada na região norte, Escola 58 também na região norte e Escola 4 região leste.

O capítulo da CID-10 "Doenças do aparelho digestivo"; é encontrado nos docentes de quatro escolas que apresentaram maior absenteísmo por motivo de saúde apresentam

Os "Transtornos mentais e comportamentais" e as "Doenças do sistema osteomuscular e do tecido conjuntivo" são encontrados em três das cinco escolas com alto índice de faltas por Motivo de Saúde.

O Capítulo da CID-10 "Fatores que influenciam o estado de saúde e o contato com os serviços de saúde" aparece em todas as cinco escolas que foram destacadas e analisadas na Tabela 9. 


\section{Gráfico 12 - Números de faltas por capítulos da CID-10 e escola}

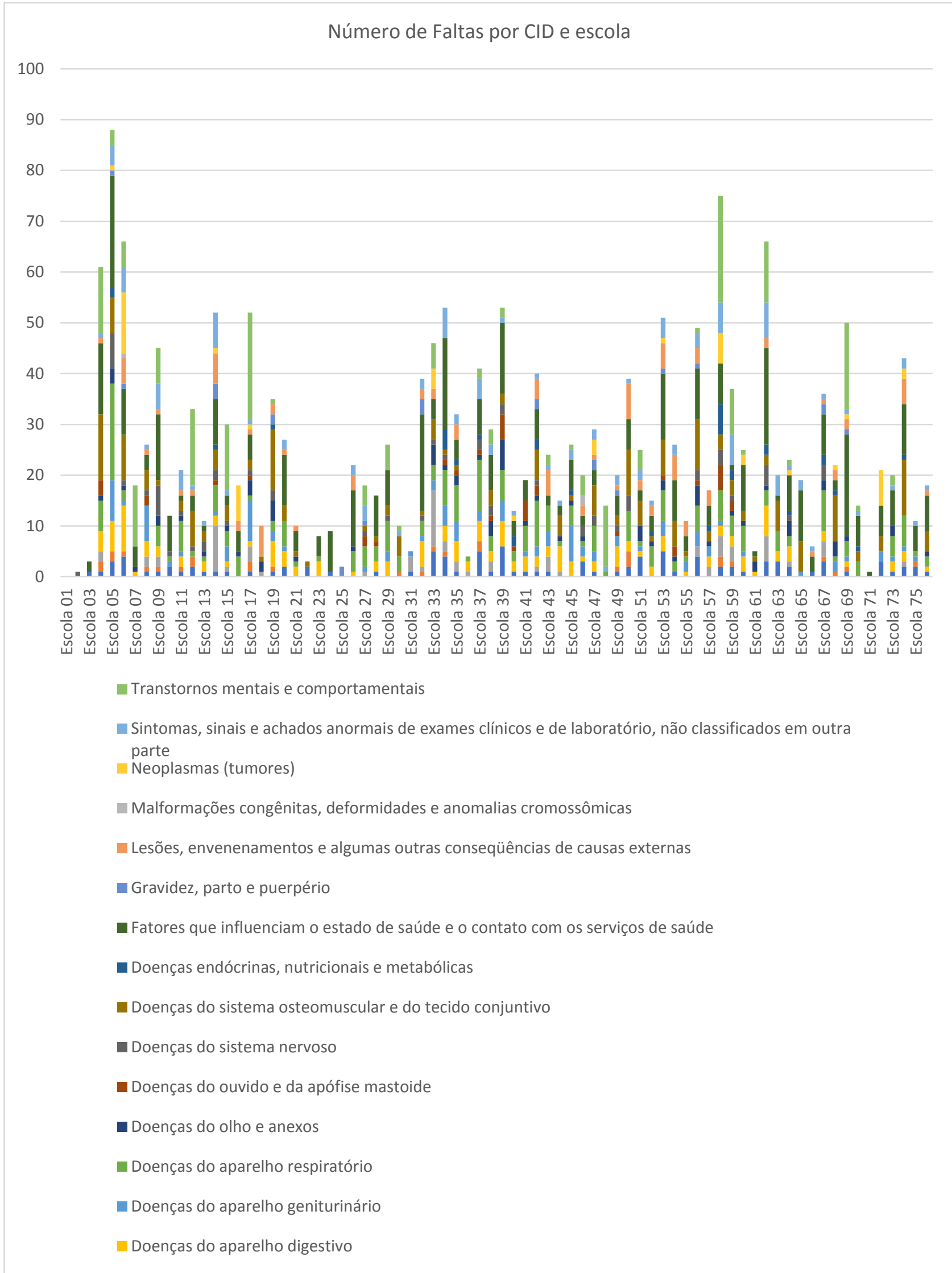

Fonte: Elaborado pelo autor com base nos dados Ribeirão Preto, 2015. 
A Tabela 11 apresenta outras características das escolas onde as licenças de saúde foram concedidas. Dentre estas características, tem-se o grau de complexidade dos estabelecimentos de ensino, se as escolas são prioritariamente de Educação Infantil - El ou de Ensino Fundamental I - EF I, juntamente com o tamanho médio das sala das escolas, além das notas do IDEB - 2015 e do total de licenças por saúde concedidas em cada escola.

Tabela 11 - Escolas por região, indicador de complexidade, atividade da escola, tamanho médio da sala, notas do IDEB e faltas por Motivo de Saúde

\begin{tabular}{|c|c|c|c|c|c|c|c|}
\hline Escola & Região & $\begin{array}{c}\text { Indicador de } \\
\text { Complexidade } \\
\text { Nível }\end{array}$ & $\begin{array}{l}\text { Atividade } \\
\text { da escola }\end{array}$ & $\begin{array}{c}\text { Tamanho } \\
\text { médio da } \\
\text { sala (EI) }\end{array}$ & $\begin{array}{l}\text { Tamanho } \\
\text { médio da } \\
\text { sala (EF I) }\end{array}$ & $\begin{array}{l}\text { Avaliação } \\
\text { IDEB }\end{array}$ & $\begin{array}{c}\text { Faltas por } \\
\text { Motivo de } \\
\text { Saúde }\end{array}$ \\
\hline Escola 1 & Norte & 1 & $\mathrm{EI}$ & & & $\begin{array}{c}\text { SEM } \\
\text { AVALIAÇÃO } \\
\text { SEM }\end{array}$ & 0 \\
\hline Escola 2 & Norte & 1 & $\mathrm{EI}$ & & & $\begin{array}{c}\text { AVALIAÇÃO } \\
\text { SEM }\end{array}$ & 1 \\
\hline Escola 3 & Leste & 3 & $\mathrm{EI}$ & & & AVALIAÇÃO & 3 \\
\hline Escola 4 & Leste & 6 & EFI & & 28,5 & 6,4 & 62 \\
\hline Escola 5 & Norte & 5 & EF I & & 29 & 5,7 & 88 \\
\hline Escola 6 & Oeste & 5 & EF I & & 26,8 & 5,5 & 66 \\
\hline Escola 8 & Leste & 2 & $\mathrm{EI}$ & 21,1 & & $\begin{array}{c}\text { SEM } \\
\text { AVALIAÇÃO } \\
\text { SFM }\end{array}$ & 26 \\
\hline Escola 9 & Leste & 2 & $\mathrm{El}$ & 18,5 & & $\begin{array}{c}\text { AVALIAÇÃO } \\
\text { SEM }\end{array}$ & 45 \\
\hline Escola 10 & Sul & 2 & El & 22,5 & & $\begin{array}{c}\text { AVALIAÇÃO } \\
\text { SEM }\end{array}$ & 12 \\
\hline Escola 11 & Oeste & 2 & $\mathrm{EI}$ & 21,8 & & $\begin{array}{c}\text { AVALIAÇÃO } \\
\text { SEM }\end{array}$ & 21 \\
\hline Escola 12 & Oeste & 1 & $\mathrm{El}$ & 23,4 & & $\begin{array}{c}\text { AVALIAÇÃO } \\
\text { SEM }\end{array}$ & 33 \\
\hline Escola 13 & Oeste & 2 & $\mathrm{El}$ & 23,0 & & $\begin{array}{c}\text { AVALIAÇÃO } \\
\text { SEM }\end{array}$ & 11 \\
\hline Escola 14 & Oeste & 2 & El & 23,0 & & $\begin{array}{c}\text { AVALIAÇÃO } \\
\text { SEM }\end{array}$ & 52 \\
\hline Escola 15 & Sul & 2 & El & 22,6 & & $\begin{array}{c}\text { AVALIAÇÃO } \\
\text { SEM }\end{array}$ & 30 \\
\hline Escola 16 & Norte & 2 & $\mathrm{EI}$ & 24,6 & & $\begin{array}{c}\text { AVALIAÇÃO } \\
\text { SEM }\end{array}$ & 18 \\
\hline Escola 17 & Norte & 2 & $\mathrm{EI}$ & 22,6 & & $\begin{array}{c}\text { AVALIAÇÃO } \\
\text { SEM }\end{array}$ & 52 \\
\hline Escola 18 & Norte & 2 & $\mathrm{El}$ & 16,8 & & $\begin{array}{c}\text { AVALIAÇÃO } \\
\text { SEM }\end{array}$ & 10 \\
\hline Escola 19 & Norte & 2 & El & 23,3 & & $\begin{array}{c}\text { AVALIACCÃO } \\
\text { SEM }\end{array}$ & 35 \\
\hline Escola 20 & Norte & 2 & El & 25,0 & & $\begin{array}{c}\text { AVALIAÇÃO } \\
\text { SEM }\end{array}$ & 27 \\
\hline Escola 21 & Leste & 2 & $\mathrm{El}$ & 20,9 & & $\begin{array}{c}\text { AVALIAÇÃO } \\
\text { SEM }\end{array}$ & 10 \\
\hline Escola 22 & Norte & 1 & El & 23,2 & & $\begin{array}{l}\text { AVALIAÇÃO } \\
\text { Con }\end{array}$ & hua \\
\hline
\end{tabular}




\begin{tabular}{|c|c|c|c|c|c|c|c|}
\hline Escola & Região & $\begin{array}{c}\text { Indicador de } \\
\text { Complexidade } \\
\text { Nível }\end{array}$ & $\begin{array}{l}\text { Atividade } \\
\text { da escola }\end{array}$ & $\begin{array}{c}\text { Tamanho } \\
\text { médio da } \\
\text { sala (EI) }\end{array}$ & $\begin{array}{l}\text { Tamanho } \\
\text { médio da } \\
\text { sala (EF I) }\end{array}$ & $\begin{array}{c}\text { Avaliação } \\
\text { IDEB }\end{array}$ & $\begin{array}{c}\text { Faltas por } \\
\text { Motivo de } \\
\text { Saúde }\end{array}$ \\
\hline Escola 23 & Leste & 2 & $\mathrm{EI}$ & 24,8 & & $\begin{array}{c}\text { SEM } \\
\text { AVALIAČÃO } \\
\text { SEM }\end{array}$ & 8 \\
\hline Escola 24 & Leste & 2 & El & 24,8 & & AVALIAÇÃO & 9 \\
\hline Escola 25 & Norte & 2 & $\mathrm{El}$ & 23,7 & & $\begin{array}{c}\text { AVALIAÇÃO } \\
\text { SEM }\end{array}$ & 2 \\
\hline Escola 26 & Oeste & 2 & $\mathrm{El}$ & 23,4 & & $\begin{array}{c}\text { AVALIAÇÃO } \\
\text { SEM }\end{array}$ & 22 \\
\hline Escola 27 & Sul & 1 & El & 25,2 & & $\begin{array}{c}\text { AVALIAÇÃO } \\
\text { SEM }\end{array}$ & 18 \\
\hline Escola 28 & Oeste & 2 & $\mathrm{El}$ & 23,0 & & $\begin{array}{c}\text { AVALIAÇÃO } \\
\text { SEM }\end{array}$ & 16 \\
\hline Escola 29 & Oeste & 2 & El & 21,8 & & $\begin{array}{l}\text { AVALIAÇÃO } \\
\text { SEM }\end{array}$ & 26 \\
\hline Escola 30 & Leste & 1 & $\mathrm{El}$ & 27,4 & & $\begin{array}{c}\text { AVALIAÇÃO } \\
\text { SEM }\end{array}$ & 10 \\
\hline Escola 31 & Norte & 2 & El & 20,9 & & $\begin{array}{c}\text { AVALIAÇÃO } \\
\text { SEM }\end{array}$ & 5 \\
\hline Escola 32 & Norte & 1 & El & 21,4 & & AVALIAÇÃO & 39 \\
\hline Escola 33 & Norte & 3 & EFI & & 26,8 & 6,5 & 46 \\
\hline Escola 34 & Oeste & 5 & EF I & & 27,6 & 6,3 & 53 \\
\hline Escola 35 & Leste & 3 & El e EF I & 22,0 & 23,3 & $\begin{array}{l}\text { SVIAM } \\
\text { AVALIAÇÃO }\end{array}$ & 32 \\
\hline Escola 36 & Norte & 5 & EF I & & 27,9 & 6 & 4 \\
\hline Escola 37 & Norte & 5 & EF I & & 25,9 & 5,4 & 41 \\
\hline Escola 38 & Leste & 5 & EF I & & 26,6 & 6,2 & 29 \\
\hline Escola 39 & Norte & 3 & El e EF I & 21,4 & 22,4 & $\begin{array}{c}\text { SEM } \\
\text { AVALIAÇÃO }\end{array}$ & 53 \\
\hline Escola 40 & Leste & 5 & EF I & & 25,1 & 6,8 & 13 \\
\hline Escola 41 & Leste & 3 & EF I & & 26,6 & 6,6 & 19 \\
\hline Escola 42 & Leste & 3 & EF I & & 25,9 & $\begin{array}{l}6,6 \\
\text { SEM }\end{array}$ & 40 \\
\hline Escola 43 & Norte & 5 & EFI & & 28,7 & AVALIAÇÃO & 24 \\
\hline Escola 44 & Leste & 3 & EF I & & 21 & 5 & 15 \\
\hline Escola 45 & Norte & 3 & EF I & & 28,8 & 6,8 & 26 \\
\hline Escola 46 & Norte & 3 & EF I & & 27,8 & 5,1 & 20 \\
\hline Escola 47 & Leste & 5 & EF I & & 23,8 & 6,5 & 29 \\
\hline Escola 48 & Leste & 3 & EF I & & 24,8 & 6,7 & 14 \\
\hline Escola 49 & Oeste & 5 & EF I & & 27,6 & 4,8 & 20 \\
\hline Escola 50 & Norte & 3 & EF I & & 25,5 & 6,3 & 39 \\
\hline Escola 51 & Norte & 3 & EF I & & 22,4 & 5,3 & 25 \\
\hline Escola 52 & Oeste & 3 & EF I & & 25,5 & 6,5 & 15 \\
\hline Escola 53 & Norte & 3 & EFI & & 24,7 & 4,8 & 51 \\
\hline Escola 54 & Leste & 5 & EF I & & 26,9 & 6,3 & 26 \\
\hline Escola 55 & Leste & 3 & EF I & & 28,6 & 6,9 & 11 \\
\hline Escola 56 & Norte & 5 & EF I & & 26,9 & 6 & 50 \\
\hline Escola 57 & Norte & 3 & EF I & & 26,5 & 7,4 & 17 \\
\hline
\end{tabular}




\begin{tabular}{|c|c|c|c|c|c|c|c|}
\hline Escola & Região & $\begin{array}{c}\text { Indicador de } \\
\text { Complexidade } \\
\text { Nível }\end{array}$ & $\begin{array}{l}\text { Atividade } \\
\text { da escola }\end{array}$ & $\begin{array}{c}\text { Tamanho } \\
\text { médio da } \\
\text { sala (EI) }\end{array}$ & $\begin{array}{l}\text { Tamanho } \\
\text { médio da } \\
\text { sala (EF I) }\end{array}$ & $\begin{array}{c}\text { Avaliação } \\
\text { IDEB }\end{array}$ & $\begin{array}{l}\text { Faltas por } \\
\text { Motivo de } \\
\text { Saúde }\end{array}$ \\
\hline Escola 58 & Norte & 6 & EFI & & 27,3 & 5,8 & 75 \\
\hline Escola 59 & Oeste & 6 & $\mathrm{EF} I$ & & 27,2 & 6,4 & 37 \\
\hline Escola 60 & Leste & 1 & $\mathrm{EI}$ & 22,5 & & $\begin{array}{c}\text { SEM } \\
\text { AVALIACCÃO } \\
\text { SEM }\end{array}$ & 25 \\
\hline Escola 61 & Oeste & 2 & $\mathrm{EI}$ & 24,5 & & $\begin{array}{c}\text { AVALIAÇÃO } \\
\text { SEM }\end{array}$ & 5 \\
\hline Escola 62 & Leste & 1 & $\mathrm{El}$ & 24,6 & & $\begin{array}{c}\text { AVALIAÇÃO } \\
\text { SEM }\end{array}$ & 66 \\
\hline Escola 63 & Leste & 1 & $\mathrm{El}$ & 26,2 & & $\begin{array}{c}\text { AVALIAÇÃO } \\
\text { SEM }\end{array}$ & 20 \\
\hline Escola 64 & Leste & 1 & $\mathrm{EI}$ & 24,8 & & $\begin{array}{c}\text { AVALIAÇÃO } \\
\text { SEM }\end{array}$ & 23 \\
\hline Escola 65 & Norte & 2 & $\mathrm{El}$ & 22,6 & & $\begin{array}{c}\text { AVALIAÇÃO } \\
\text { SEM }\end{array}$ & 19 \\
\hline Escola 66 & Leste & 1 & $\mathrm{El}$ & 23,3 & & $\begin{array}{c}\text { AVALIAÇÃO } \\
\text { SEM }\end{array}$ & 6 \\
\hline Escola 67 & Leste & 1 & $\mathrm{El}$ & 24,1 & & $\begin{array}{c}\text { AVALIAÇÃO } \\
\text { SEM }\end{array}$ & 37 \\
\hline Escola 68 & Norte & 2 & $\mathrm{El}$ & 23,4 & & $\begin{array}{c}\text { AVALIAÇÃO } \\
\text { SEM }\end{array}$ & 22 \\
\hline Escola 69 & Leste & 2 & $\mathrm{El}$ & 24,7 & & $\begin{array}{c}\text { AVALIAÇÃO } \\
\text { SEM }\end{array}$ & 50 \\
\hline Escola 70 & Norte & 2 & $\mathrm{El}$ & 25,1 & & $\begin{array}{c}\text { AVALIAÇÃO } \\
\text { SEM }\end{array}$ & 14 \\
\hline Escola 71 & Oeste & 1 & $\mathrm{EI}$ & & & $\begin{array}{c}\text { AVALIAÇÃO } \\
\text { SEM }\end{array}$ & 1 \\
\hline Escola 72 & Oeste & 2 & $\mathrm{EI}$ & 24,3 & & $\begin{array}{c}\text { AVALIAÇÃO } \\
\text { SEM }\end{array}$ & 21 \\
\hline Escola 73 & Norte & 1 & $\mathrm{El}$ & 21,8 & & $\begin{array}{c}\text { AVALIAÇÃO } \\
\text { SEM }\end{array}$ & 20 \\
\hline Escola 74 & Norte & 2 & $\mathrm{EI}$ & 27,6 & & $\begin{array}{c}\text { AVALIAÇÃO } \\
\text { SEM }\end{array}$ & 43 \\
\hline Escola 75 & Leste & 2 & $\mathrm{EI}$ & 22,8 & & $\begin{array}{c}\text { AVALIAÇÃO } \\
\text { SEM }\end{array}$ & 11 \\
\hline Escola 76 & Oeste & 1 & $\mathrm{EI}$ & 24,5 & & AVALIAÇÃO & 18 \\
\hline
\end{tabular}

Fonte: Elaborado pelo autor com base nos dados Ribeirão Preto, 2015 e dados IDEB, 2015.

O Instituto Nacional de Estudos e Pesquisas Educacionais Anísio Teixeira do Ministério da Educação (INEP - MEC) desenvolveu um indicador de complexidade de gestão dos estabelecimentos de ensino compondo dados como os de tamanho ou porte da escola, número de turnos, número e complexidade da etapa de ensino.

Por este indicador, as escolas têm diferentes graus de complexidade administrativa, pois diferem em termos de tamanho (número de alunos, não apenas por sala, mas para o estabelecimento como um todo); número de turnos (se apenas ou mais de um turnos entre os matutinos, vespertinos, diurnos, noturnos etc.); número de etapas que são realizadas neles (ou seja existem estabelecimentos que se 
concentram exclusivamente em uma etapa, mas outros envolvem diferentes etapas), além de se poder considerar que cada uma das diferentes etapas possuem graus de complexidade diferentes (etapas que envolvem alunos em idades mais avançadas sendo por vezes consideradas mais complexos).

$O$ indicador classifica os estabelecimentos em diferentes níveis de complexidade, conforme observa-se no Quadro 3.

Quadro 3 - Complexidade de Gestão dos estabelecimentos de ensino

- Nível 1 - Escolas que, em geral, possuem porte inferior a 50 matrículas, funcionam em único turno, ofertam uma única etapa de ensino e apresentam a Educação Infantil ou os Anos Iniciais como etapa mais elevada.

- Nível 2 - Escolas que, em geral, possuem porte entre 50 e 300 matrículas, funcionam em 2 turnos, com oferta de até 2 etapas de ensino e apresentam a Educação Infantil ou os Anos Iniciais como etapa mais elevada.

- Nível 3 - Escolas que, em geral, possuem porte entre 50 e 500 matrículas, funcionam em 2 turnos, com oferta de 2 ou 3 etapas de ensino e apresentam os Anos Finais como etapa mais elevada.

- Nível 4 - Escolas que, em geral, possuem porte entre 150 e 1000 matrículas, funcionam em 2 ou 3 turnos, com oferta de 2 ou 3 etapas de ensino e apresentam o Ensino Médio, a Educação Profissional ou a EJA - Educação de Jovens e Adultos - como etapa mais elevada.

- Nível 5 - Escolas que, em geral, possuem porte entre 150 e 1000 matrículas, funcionam em 3 turnos, com oferta de 2 ou 3 etapas de ensino e a EJA como etapa mais elevada.

- Nível 6 - Escolas que, em geral, possuem porte superior a 500 matrículas, funcionam em 3 turnos, com oferta de 4 ou mais etapas de ensino e apresentam a EJA como etapa mais elevada.

Fonte: INEP (2008)

Com relação a este indicador de complexidade, como pode ser visto no quadro acima, as Escolas Municipais de Ribeirão Preto estão distribuídas nos níveis 1, 2, 3, 5 e 6. De acordo com a avaliação do INEP, não temos escolas de nível 4 na Rede Municipal. Como mostra a Tabela 12, a maioria das escolas de Municipais são 
classificadas como nível 2 (28 escolas, 38\%), e em segundo lugar as escolas estão no nível 3 do indicador de complexidade (16 escolas, 21\%).

Sobre a distribuição da concessão de licenças, observa-se que a maioria do Total de Licenças e das licenças por Motivo de Saúde são concedidas para o grupo de escolas de complexidade nível 2 (1482 licenças - 34\% do total - sendo 622 licenças saúde - 31\%), vindo a seguir o total de licenças concedidas às escolas do nível 5.

Tabela 12 - Indicador de complexidade por dados do absenteísmo

\begin{tabular}{|c|c|c|c|c|c|c|c|c|c|}
\hline \multirow[b]{2}{*}{$\begin{array}{l}\text { Indicador de } \\
\text { Complexidade }\end{array}$} & \multicolumn{8}{|c|}{ Número total de licenças } & \multirow{2}{*}{$\begin{array}{c}\text { Número } \\
\text { de } \\
\text { escolas } \\
\text { em cada } \\
\text { nível }\end{array}$} \\
\hline & $\begin{array}{c}\text { Falta } \\
\text { Abonada }\end{array}$ & $\begin{array}{l}\text { Licenças } \\
\text { por } \\
\text { Motivo } \\
\text { de Saúde }\end{array}$ & Outros & $\begin{array}{l}\text { Licença } \\
\text { Gala }\end{array}$ & $\begin{array}{c}\text { Prorrogação } \\
\text { Licença } \\
\text { Gestante }\end{array}$ & $\begin{array}{l}\text { Licença } \\
\text { Nojo }\end{array}$ & $\begin{array}{l}\text { Licença } \\
\text { Prêmio }\end{array}$ & $\begin{array}{c}\text { Licenças } \\
\text { Total }\end{array}$ & \\
\hline Nível 1 & 326 & 320 & 3 & 2 & 4 & 11 & 11 & 677 & 16 \\
\hline Nível 2 & 764 & 622 & 10 & 6 & 10 & 12 & 58 & 1482 & 28 \\
\hline Nível 3 & 362 & 426 & 3 & 3 & 2 & 9 & 12 & 817 & 16 \\
\hline Nível 5 & 482 & 443 & 3 & 5 & 7 & 14 & 17 & 971 & 12 \\
\hline Nível 6 & 161 & 174 & 2 & 1 & 3 & 3 & 14 & 358 & 3 \\
\hline
\end{tabular}

Fonte: Elaborado pelo autor com base nos dados Ribeirão Preto, 2015.

Apenas 3 escolas são de nível 6, ou seja, 4\% do total de escolas, mas neste nível foram concedidas 174 licenças saúde, $9 \%$ do total. Isto se deve ao fato que, em média, concederam-se 58,00 licenças por Motivo de Saúde por ano nestas escolas, mais do que nas outras faixas.

O Gráfico 13 compara o número médio de licenças por Motivo de Saúde e do total das licenças nas escolas em cada nível de grau de complexidade da gestão nas escolas. A Rede Municipal de ensino tem 12 escolas de nível 5 e nestas, em média, concede-se 36,93 licenças saúde. Já nas 16 escolas de nível 3 foram concedidas em média 26,63 licenças saúde, nas 28 escolas de nível 2 foram concedidas em média 22,21 licenças saúde e nas 16 de nível 1, concede-se 20,38 licenças saúde em média.

Observa-se, assim, que, em média, quanto maior a complexidade da escola, maior o número de Licenças por Motivo de saúde são concedidas, ou seja, quanto mais complexa a escola, o número de licenças por saúde concedidas tende a ser maior para estas escolas. Esta constatação está claramente correlacionada ao maior 
número de professores que também, em média, executam suas atividades nas escolas mais complexas.

Gráfico 13 - Média das concessões de licenças por escolas e por grau de complexidade das escolas

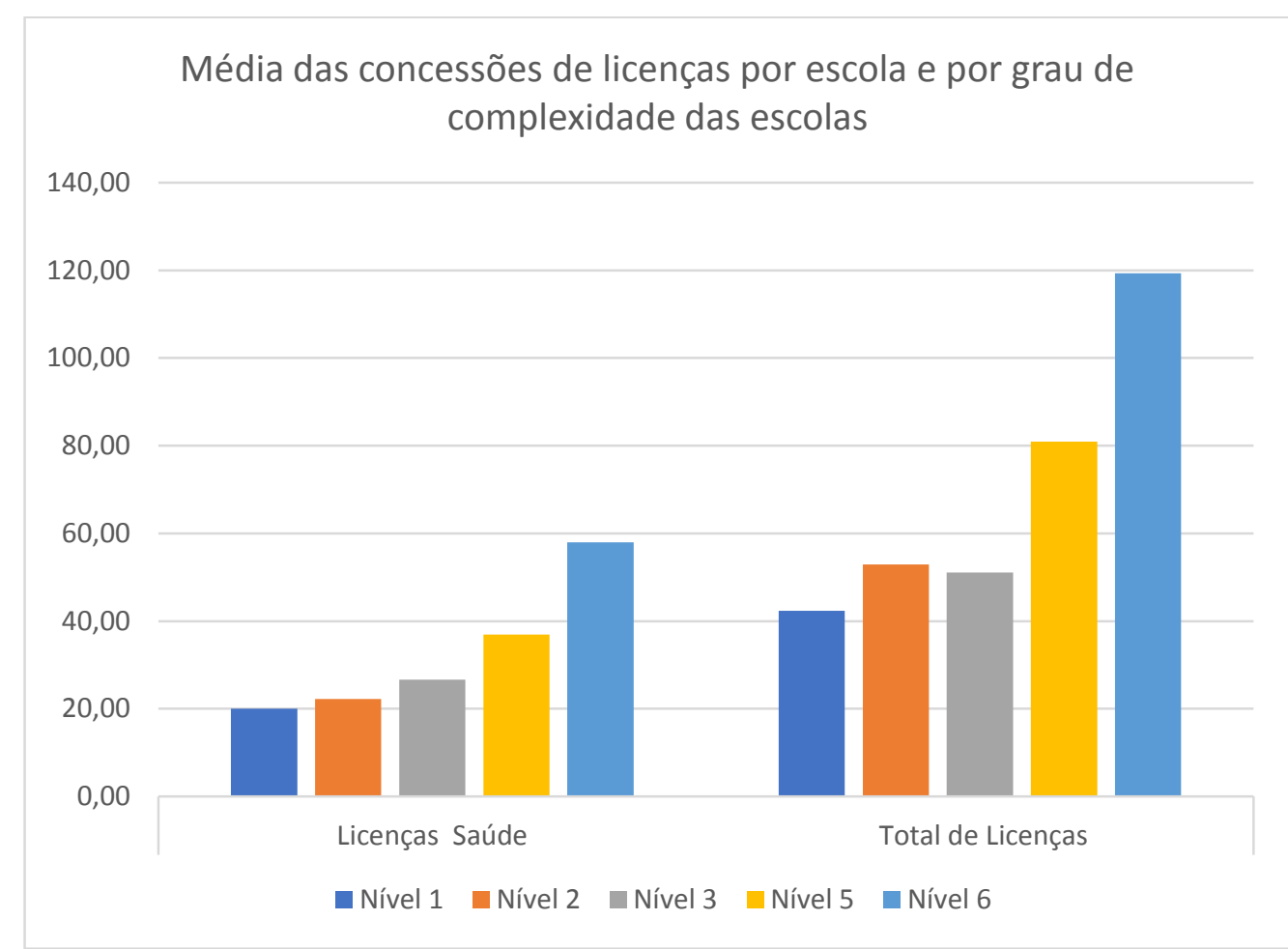

Fonte: Elaborado pelo autor com base nos dados Ribeirão Preto, 2015.

Ainda de certa forma relacionada a complexidade e ao tamanho das escolas, pode-se observar, a seguir, a Tabela 13, onde se distribui o total de licenças e o número médio de licenças nas escolas subdividas em escolas que atuam no Ensino Fundamental I e na Educação Infantil ao menos prioritariamente. 
Tabela 13 - Número médio e total de licenças concedidas por tipo de licença e faixa educativa principal da unidade escolar

\begin{tabular}{|c|c|c|c|c|c|c|c|c|c|}
\hline & & $\begin{array}{c}\text { Falta } \\
\text { Abonada }\end{array}$ & $\begin{array}{l}\text { Licenças } \\
\text { por } \\
\text { Motivo de } \\
\text { Saúde }\end{array}$ & Outros & $\begin{array}{l}\text { Licença } \\
\text { Gala }\end{array}$ & $\begin{array}{c}\text { Prorrogação } \\
\text { Licença } \\
\text { Gestante }\end{array}$ & $\begin{array}{c}\text { Licença } \\
\text { Nojo }\end{array}$ & $\begin{array}{l}\text { Licença } \\
\text { Prêmio }\end{array}$ & $\begin{array}{c}\text { Licenças } \\
\text { Total }\end{array}$ \\
\hline \multirow{2}{*}{$\begin{array}{l}\text { Educação } \\
\text { Infantil }\end{array}$} & $\begin{array}{l}\text { Número } \\
\text { médio } \\
\text { de } \\
\text { licenças }\end{array}$ & 26,86 & 23,84 & 0,30 & 0,19 & 0,33 & 0,58 & 1,65 & 53,74 \\
\hline & $\begin{array}{l}\text { Número } \\
\text { total de } \\
\text { licenças }\end{array}$ & 1155 & 1025 & 13 & 8 & 14 & 25 & 71 & 2311 \\
\hline \multirow{2}{*}{$\begin{array}{c}\text { Ensino } \\
\text { Fundamental }\end{array}$} & $\begin{array}{l}\text { Número } \\
\text { médio } \\
\text { de } \\
\text { licenças }\end{array}$ & 33,43 & 34,67 & 0,27 & 0,30 & 0,37 & 0,87 & 1,43 & 71,33 \\
\hline & $\begin{array}{l}\text { Número } \\
\text { total de } \\
\text { licenças }\end{array}$ & 1003 & 1040 & 8 & 9 & 11 & 26 & 43 & 2140 \\
\hline
\end{tabular}

Fonte: Elaborado pelo autor com base nos dados Ribeirão Preto, 2015.

Percebe-se que as escolas prioritariamente relacionadas à Educação Infantil que alcançam 59\% do total de estabelecimentos, concedem aproximadamente $49,5 \%$ das licenças saúde, pois em média cada um destes estabelecimentos concede, em média, 23,84 licenças saúde. Este número médio de licenças saúde concedidas é menor do que aquelas concedidas pelos estabelecimentos prioritariamente dedicados à Educação Fundamental I, os quais, em média, concedem 34,67 licenças saúde por estabelecimento.

Pelos dados anteriormente apresentados na Tabela 11, pode-se observar também o tamanho médio das salas de aula destes estabelecimentos, o número médio de alunos por sala de aula em que o professor atua. Porém a correlação obtida entre estes dados e o número de licenças saúde $(-0,08)$, a princípio não nos permite fazer relações muito significativas entre estas concessões de licenças e este tipo de característica dos estabelecimentos - o tamanho das turmas de alunos nas salas de 
aula - o que algumas vezes é alegado como possível causa de incidência de certas causas de absenteísmo docente. Tal hipótese carece aqui de uma análise mais detida.

A baixa correlação também é verificada quando se analisa a relação entre as licenças por estabelecimento e o IDEB. Já o IDEB, Índice de Desenvolvimento da Educação Básica, também criado pelo, INEP, avalia a qualidade dos ensinos fundamentais e médios em escolas públicas e privadas de todo o pais, a "nota" do ensino básico varia numa escala de 0 a 10 . 0 indicador é divulgado a cada dois anos e é calculado com base nos dados do Censo Escolar (com informações enviadas pelas escolas e redes) acerca do fluxo escolar (dados de aprovação/retenção) e nas médias de desempenho dos alunos de final de ciclo nas avaliações efetuadas pelo Instituto Nacional de Estudos e Pesquisa, especialmente a Prova Brasil (INEP, 2015).

Não são todas as Escolas Municipais de Ribeirão Preto que possuem avaliação do IBEB. As escolas de Educação Infantil de 0 a 5 anos não participam destas avaliações, pois não realizam provas formais com avaliação de letramento. Das Escolas Municipais de Ribeirão Preto analisadas neste trabalho, apenas 28 possuem avaliação do IDEB e a princípio este indicador possui uma correlação $(-0,1)$ baixa e negativa com as licenças concedidas por estes estabelecimentos. Esta relação era uma relação que poderia ser esperada e que poderia explicar por exemplo, um desempenho mais fraco no processo de aprendizagem dos alunos em função do absenteísmo docente. Uma análise mais detida, porém, deve ser realizada para confirmar, ou não, esta hipótese.

A Tabela 14, a seguir, destaca as cinco escolas com maior incidência de licenças saúde e nesta tabela, observa-se também os motivos de licenças saúde de cada escola e nota de avaliação do IDEB. Nota-se que são escolas de maior complexidade (nível 5 e 6) e em geral ligadas ao Ensino Fundamental I. Porém, encontra-se também, entre as cinco com maior incidência de licença saúde, uma escola pouco complexa (nível 1) e ligada à Educação Infantil. 
Tabela 14 - Escolas com maior ocorrência de LTS, principais capítulos da CID-10 e número de casos

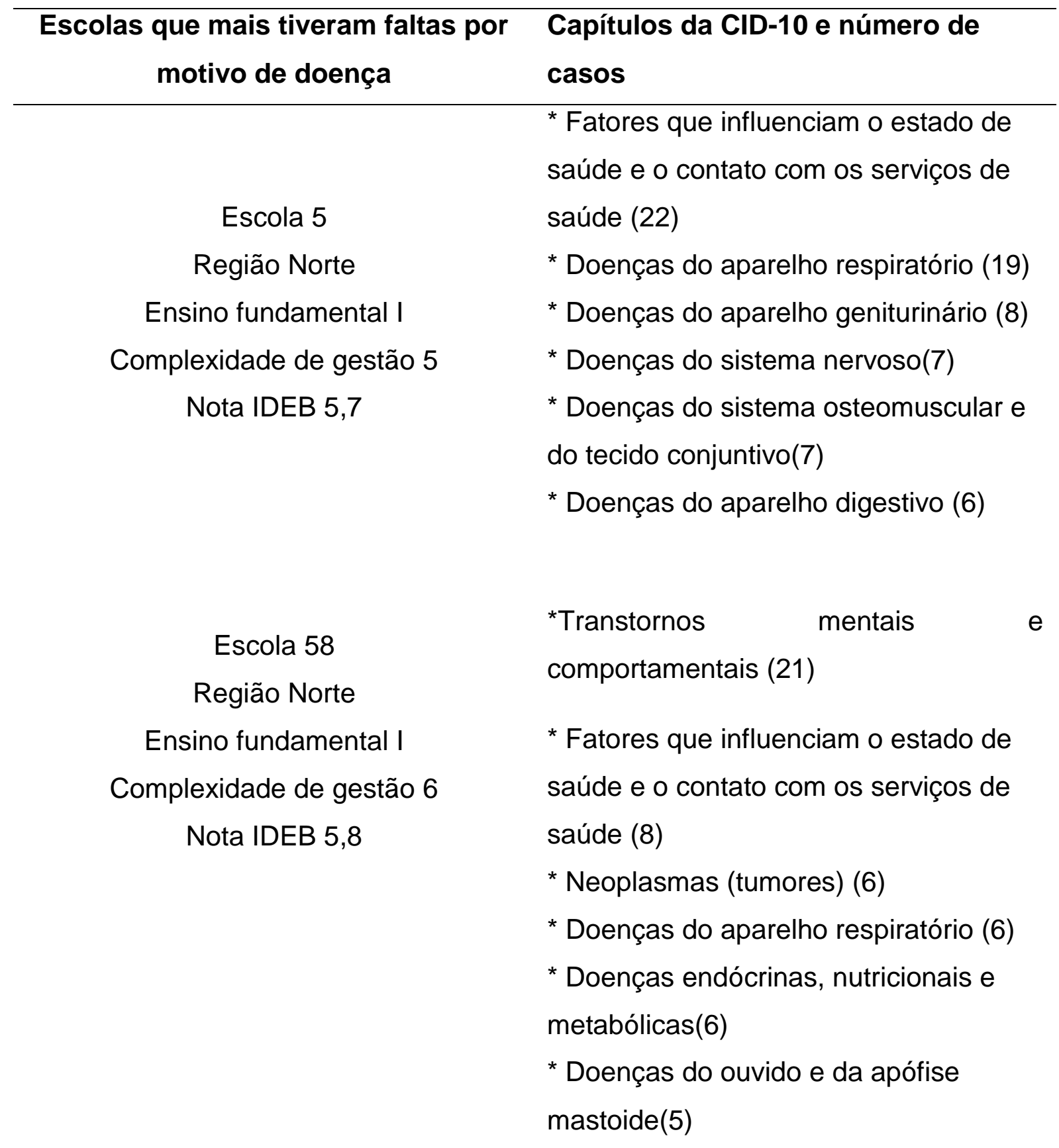


Continuação

\begin{tabular}{|c|c|}
\hline $\begin{array}{l}\text { Escolas que mais tiveram faltas por } \\
\text { motivo de doença }\end{array}$ & $\begin{array}{l}\text { Capítulos da CID-10 e número de } \\
\text { casos }\end{array}$ \\
\hline & ${ }^{*}$ Neoplasmas (tumores) (12) \\
\hline & * Doenças do aparelho digestivo (9) \\
\hline & ${ }^{*}$ Fatores que influenciam o estado de \\
\hline Escola 6 & saúde e o contato com os serviços de \\
\hline Região Oeste & saúde (9) \\
\hline Ensino fundamental I & ${ }^{*}$ Doenças do sistema osteomuscular e \\
\hline Complexidade de gestão 5 & do tecido conjuntivo(9) \\
\hline \multirow[t]{7}{*}{ Nota IDEB 5,5} & * Lesões, envenenamento e algumas \\
\hline & outras consequências de causas \\
\hline & externas(5) \\
\hline & * Sintomas, sinais achados anormais de \\
\hline & exames clínicos e de laboratório(5) \\
\hline & ${ }^{*}$ Fatores que influenciam o estado de \\
\hline & saúde e o contato com os serviços de \\
\hline Escola 62 & saúde (19) \\
\hline Região Leste & Transtornos \\
\hline Educação Infantil & comportamentais (12) \\
\hline Complexidade de gestão 1 & * Sintomas, sinais achados anormais de \\
\hline \multirow[t]{4}{*}{ Sem avaliação do IDEB } & exames clínicos e de laboratório(7) \\
\hline & ${ }^{*}$ Doenças do aparelho digestivo (6) \\
\hline & * Doenças do aparelho circulatório(5) \\
\hline & * Doença do sistema nervoso(4) \\
\hline
\end{tabular}


Conclusão

$\begin{array}{cl}\begin{array}{c}\text { Escolas que mais tiveram faltas por } \\ \text { motivo de doença }\end{array} & \begin{array}{l}\text { Capítulos da CID-10 e número de } \\ \text { casos }\end{array} \\ & \begin{array}{c}\text { * } \text { Fatores que influenciam o estado de } \\ \text { saúde e o contato com os serviços de } \\ \text { saúde (14) }\end{array} \\ \text { Escola } 4 & { }^{*} \text { Transtornos mentais } \\ \text { Região Leste Ensino fundamental I } & \text { comportamentais (13) } \\ \text { Região Leste } & { }^{*} \text { Doenças do sistema osteomuscular e } \\ \text { Complexidade de gestão } 6 & \text { do tecido conjuntivo(13) } \\ \text { Nota IDEB 6,4 } & { }^{*} \text { Doenças do aparelho respiratório (6) } \\ & { }^{*} \text { Doença do aparelho digestivo (4) } \\ & \text { *Doenças do ouvido e da apófise } \\ & \text { mastoide(3) }\end{array}$

Fonte: Elaborado pelo autor com base nos dados Ribeirão Preto, 2015. 


\section{CONCLUSÃO}

O docente exerce uma das profissões mais estressantes devido a longas jornadas de trabalho, ritmo intenso e diversas variáveis que influenciam em sua vida profissional. As situações variadas do cotidiano da sala de aula têm como resultado fatores físicos e psicológicos, gerando problemas de saúde podem acarretar o aumento nos índices de absenteísmo, aumentando o número de licenças médicas $O$ trabalho procurou analisar o absenteísmo por doença dos docentes no ensino fundamental em instituições públicas municipais de ensino da cidade de Ribeirão Preto no ano de 2014.

$A$ análise deste trabalho se restringiu aos professores efetivos e eventuais PEB II - Professores da Educação Básica II - que englobavam a Educação Infantil (crianças de 4 e 5 anos) e o Ensino Fundamental I (1ํㅡ a $5^{\circ}$ ano) presentes em 75 escolas municipais. Para tal, foi necessário quantificar os números de absenteísmo, separar as ausências por doenças e as licenças por motivos variados, que afetaram os professores de PEB II em 2014

Para a análise das licenças médicas, foi utilizado a Classificação Estatística Internacional de Doenças e Problemas Relacionados à Saúde (também conhecida como Classificação Internacional de Doenças - CID-10) que é publicada pela Organização Mundial de Saúde (OMS) e visa padronizar a codificação de doenças e outros problemas relacionados à saúde.

Foram isoladas e analisadas as licenças médicas dos docentes e quantificadas quais as doenças que mais acometem estes professores, fazendo também comparativos com idade, sexo e as escolas em que ocorreram os maiores índices de absenteísmo.

Dos 991 professores de Educação Básica II em atividade em 2014, 748 tiraram 4.324 licenças por vários motivos: 2095 Faltas Abonadas, 2003 faltas por Motivo de Saúde, 112 Licenças Prêmio, 49 Licenças Nojo, 26 Prorrogação de Licenças Gestante. 17 Licenças Gala e 21 outros motivos não definidos.

Mesmo o absenteísmo por Motivo de Doença dos docentes de Educação Básica II da Rede Municipal estando em segundo lugar, o total de número de faltas por Motivos de Saúde é alto, pois não se pode esquecer que o atestado médico pode conter Licença para Tratamento de Saúde - LTS - de vários dias (até 15 dias, de mais de 16 dias, 30 dias, 90, 120 dias ou mais). Desta forma, o número de licenças não 
corresponde ao número de dias afastados, ou seja, o número de atestados são menores que os dias sem docente em sala de aula. $O$ total de número de dias perdidos por absenteísmo relacionado à Licença de Tratamento de Saúde - LTS, é de 14.957 dias de ausência do docente efetivo nas salas de PEB II.

Dentre de todas as licenças de saúde, as principais causas de afastamentos, por motivo de saúde dos professores do Educação Básica II, estão dentro dos seguintes capítulos da CID-10: "fatores que influenciam o estado de saúde e o contato com os serviços de saúde" (Códigos Z00 - Z99), "doenças relacionadas ao aparelho respiratório" (Códigos J00 - J99), "transtornos mentais e comportamentais" (Códigos F00 - F99) e "doenças do sistema osteomuscular e do tecido conjuntivo" (Códigos M00 - M99).

As faixas etárias que mais tiraram licenças por motivo de saúde foram as entre 30 a 39 anos e 40 a 49 anos. Os motivos das licenças são diferentes de acordo com a faixa etária: entre 20 a 29 anos temos em primeiro lugar "os transtornos mentais e comportamentais" $(27,27 \%)$, em segundo os "fatores que influenciam o estado de saúde e o contato com os serviços de saúde" (18,18\%); Os professores entre 30 a 39 anos tiram mais licenças médicas por "fatores que influenciam o estado de saúde e o contato com os serviços de saúde" $(29,17 \%)$, seguida de "doenças do aparelho respiratório (14,17\%); Já os docentes na faixa etária entre 40 a 49 se ausentam também em primeiro lugar por "fatores que influenciam o estado de saúde e o contato com os serviços de saúde" $(20,83 \%)$, mas em segundo lugar as faltas são por transtornos mentais e comportamentais; Entre 50 -59 os principais motivos das licenças são as "doenças do sistema osteomuscular e do tecido conjuntivo" $(20,22 \%)$ e "fatores que influenciam o estado de saúde e o contato com os serviços de saúde" $(14,61 \%)$ e acima de 60 anos os atestados de saúde são devido às "doenças do sistema osteomuscular e do tecido conjuntivo" (18,79\%) e às "lesões, envenenamentos e algumas outras consequências de causas externas" (13,42\%).

Conclui-se que as doenças que afetam as mulheres de suas atividades docentes são diferentes das que afetam os homens. As quatro principais doenças que aparecem nos atestados das professoras são "Fatores que influenciam o estado de saúde e o contato com os serviços de saúde" (22,04\%); "Doenças do aparelho respiratório" (11,60\%); "Transtornos mentais e comportamentais" (10,08\%); "Doenças do sistema osteomuscular e do tecido conjuntivo" (10,03\%). No grupo de homens, estão presentes as seguintes doenças: "Algumas doenças infecciosas e parasitárias" 
(17,14\%); "Doenças do sistema osteomuscular e do tecido conjuntivo" (17,14\%); "Doenças do aparelho digestivo" (14,29\%); "Doenças do aparelho respiratório" $(11,43 \%)$.

Relacionando as licenças por Motivo de Saúde por escolas nas regiões de Ribeirão Preto, nota-se que a região Norte engloba $40 \%$ das escolas e também é a que mais apresenta licenças e licenças saúde. Foram concedidas um total de 869 licenças saúde nas escolas da região (44\% do total), vindo a seguir as regiões Leste (com $35 \%$ das escolas e 639 licenças saúde - 32\% do total), Oeste (com $21 \%$ das escolas e 417 licenças saúde $21 \%$ do total) e Sul (4\% das escolas e 60 licenças saúde concedidas, $3 \%$ do total).

Em relação ao número médio de licenças concedidas por Motivo de Saúde por escolas nas regiões, conclui-se que a região Norte teve uma média de 28,97 licenças por escola frente à região Leste com 24,58; a região Oeste com 26,06 e região Sul teve média de 20,00 licenças. A região Norte de Ribeirão Preto tem um maior número de licenças concedidas, pois existem mais escolas nesta região e também porque se concedem, em média, mais licenças saúde por escola desta região.

Observou-se que quanto maior a complexidade da escola, maior o número de licenças concedidas por Motivo de Saúde, ou seja, quanto mais complexa a escola, o número de licenças por saúde concedidas tende a ser maior para estas escolas. Esta constatação está claramente correlacionada ao maior número de professores que também, em média, executam suas atividades nas escolas mais complexas.

As limitações deste trabalho estão associadas ao fato de que em algumas licenças médicas não estavam especificadas a CID-10 correspondente, dificultando o agrupamento das mesmas para análise, surgindo assim o item outros motivos de absenteísmo.

Além disto não foram encontradas avaliações de algumas escolas municipais, ausência que limitou na análise da relação entre as notas e o absenteísmo.

Outros estudos que aprofundem o tema absentismo por doença dos docentes são necessários. Um estudo comparativo entre Rede Municipal, Rede Estadual e Rede Particular de Educação seria fundamental para observar como se dá os motivos das licenças dos docentes.

Para diminuir esse índice, é necessário estudos mais aprofundados com evidências fornecidas pela epidemiologia e outras disciplinas relevantes para a realização de um programa de prevenção do absenteísmo por doenças junto à 
Secretaria Municipal de Educação. Ações de prevenções são necessárias, pois os problemas de saúde podem acarretar o aumento nos índices de absenteísmo, que por sua vez, aumenta o número de licenças médicas, e por consequência, gera a necessidade de reposição de docentes, novas despesas, ou defasagem no processo de aprendizagem. 


\section{REFERÊNCIAS}

ALTOÉ, A. Políticas Institucionais e seus desdobramentos sobre o trabalho docente: absenteísmo e presenteísmo. 2010. 140 f. Dissertação (Mestrado) - Pontifícia Universidade Católica de Minas Gerais, Belo Horizonte, 2010. Disponível em: $<$ http://dominiopublico.qprocura.com.br/dp/114980/politicas-institucionais-e-seusdesdobramentos-sobre-o-trabalho-docente-absenteismo-e-presenteismo.html>. Acesso em: 10 jan. 2016.

CHIAVENATO, I. Gestão de pessoas: o novo papel dos recursos humanos nas organizações. 3. ed. Rio de Janeiro: Elsevier, 2008.

CODO, W.; SAMPAIO, J.; HITOMI, A. Indivíduo, trabalho e sofrimento. Petrópolis: Vozes, 1994.

FRANCO, L. J.; PASSOS, A. D. C. (Orgs.). Fundamentos de epidemiologia. 2. ed. Barueri: Manole, 2011.

GATTI, B. A. Estudos quantitativos em educação. Educação e Pesquisa, São Paulo, v. 30, n. 1, p. 11-30, jan./abr. 2004.

GORDIS, L. Epidemiologia. 5. ed. Rio de Janeiro: Thieme Revinter, 2017.

INSTITUTO NACIONAL DE ESTUDOS E PESQUISA EDUCACIONAIS ANÍSIO TEIXEIRA (INEP). Indicadores Educacionais. 2015 Disponível em: $<$ http://portal.inep.gov.br/web/guest/censo-escolar $>$. Acesso em: 07 nov. 2016.

MINAYO, M. C. S. (Org.). Pesquisa social: teoria, método e criatividade. Rio de Janeiro: Vozes, 2001.

ORGANISATION FOR ECONOMIC CO-OPERATION AND DEVELOPMENT (OECD). PISA 2012 results: what makes schools successful?: resources, policies and practices. (Volume IV). 2013. Disponível em: <https://www.oecd.org/pisa/keyfindings/pisa-2012results-volume-IV.pdf >. Acesso em: 20 nov. 2016.

ORGANIZAÇÃO MUNDIAL DE SAÚDE (OMS). Centro Colaborador da OMS para a Classificação de Doenças em Português. Classificação Estatística Internacional de Doenças e Problemas Relacionados à Saúde: CID-10. 2008. Disponível em: $<$ http://www.datasus.gov.br/cid10/V2008/cid10.htm>. Acesso em: 10 mar. 2017.

RIBEIRÃO PRETO. Prefeitura Municipal Portal da Transparência. E-sic: Sistema Eletrônico do Serviço de Informação ao Cidadão. 2015. Disponível em: $<$ http://www.ribeira.opreto.sp.gov.br/J324/index.xhtml>.

Acesso em: 13 out. 2015. 
ROCHA, V. M.; FERNANDES, M. H. Qualidade de vida de professores do ensino fundamental: uma perspectiva para a promoção da saúde do trabalhador. Jornal Brasileiro de Psiquiatria, v. 57, n. 1, p. 23-27, 2008. Disponível em:

$<$ http://www.scielo.br/pdf/jbpsiq/v57n1/v57n1a05.pdf >. Acesso em: 10 fev. 2016.

SANTOS, C. M. C. et al. A estratégia PICO para a construção da pergunta de pesquisa e busca de evidências. Revista Latino-americana de Enfermagem, v. 15, n. 3, p. 508511, 2007. Disponível em: <http://www.scielo.br/pdf/rlae/v15n3/pt v15n3a23.pdf>. Acesso em: 20 fev. 2016.

SANTOS, S. L. D. O que fazer mediante ao absenteísmo docente? Análise sobre orientações da secretaria municipal de educação de São Paulo no período de 2004/2005. São Paulo: Pontifícia Universidade Católica de São Paulo, 2006.

SAVIANI, D. História da história da educação no Brasil: um balanço prévio e necessário. EccoS Revista Científica, São Paulo, v. 10, p. 147-167, jul. 2008. Número especial.

SILVA, D. M. P. P.; MARZIALE, M. H. P. Absenteísmo de trabalhadores de enfermagem em um hospital universitário. Revista Latino-americana de Enfermagem, Ribeirão Preto, v. 8, n. 5, p. 44-51, out. 2000.

SILVA, E. B. F. et al. Transtornos mentais e comportamentais: perfil dos afastamentos de servidores públicos estaduais em Alagoas. 2009. Epidemiologia e Serviços de Saúde, Brasília, v. 21, n. 3. p. 505-514, 2012.

SOUZA, K. R. et al. Trajetória do Sindicato Estadual dos Profissionais da Educação do Rio de Janeiro (SEPE-RJ) na luta pela saúde no trabalho. Ciência e Saúde Coletiva, Rio de Janeiro, v. 8, n. 4, p.1057-1068, 2003.

SPÓSITO, L. S. et al. Saúde e absenteísmo docente: uma breve revisão de literatura. Revista Eletrônica Gestão \& Saúde, cidade, v. 5, n. 3, p. 2096 - 2114, 2014.

VENSON, A. et al. O recurso mais importante para as organizações são mesmo as pessoas? Uma análise da produção científica sobre qualidade de vida no trabalho (QVT). Revista de Administração da UFSM, Santa Maria, v. 6, n. 1, p. 139-156, 2013. 
APÊNDICE A - Relação das 75 escolas que englobam PEB II

- 42 Escolas Municipais de Educação Infantil - EMEls (crianças de 4 a 5 anos)

Adriana Coutinho Brandani Camilo (região leste)

Albert Einstein (região leste)

Aloizio Olaia Paschoal (região leste)

Amélia Junqueira (região leste)

Amélia Sofia Rodrigues da Costa, Prof ${ }^{\underline{a}}$ (região leste)

Ana dos Santos Gabarra (região sul)

Anita Procópio Junqueira (região oeste)

Áurea Apparecida Braghetto Machado (região oeste)

Caetana Spinelli Martins (região oeste)

Carmen Aparecida de Carvalho Ramos (região leste)

Carmem Massarotto, Prof. ${ }^{a}$ (região oeste)

Elza Guazzelli Da Costa, Prof. a (região norte)

Emílio Jarbinet, Pe. (região leste)

Henilla Godoy Velludo Salvador (região norte)

Hilda Maria Sobral Barbosa Mandarino (região norte)

Hilda Mosca (região leste)

Iria Junqueira (Bonfim Paulista)

João Sperandio, Dep. (região oeste)

José Bonifácio Coutinho Nogueira (região norte)

José Carlos Sobral, Dr (região leste)

José Pedro Moreira, Prof. (região oeste)

José Roberto Felício $\mathrm{Dr}^{\circ}$ (região leste)

Lilian Spadaro Rosa e Silva, Prof. ․ (região norte)

Maria Aparecida de Almeida Paulino (região norte)

Maria Apparecida Borges de Oliveira Bonini, Prof ${ }^{\underline{a}}$ (região oeste)

Maria Goretti, Santa (região oeste)

Maria Helena Braga Monte Serrat Dr ${ }^{\mathrm{a}}$ (região norte)

Maria Pontim (região norte)

Marlene Jorge dos Reis, Prof $^{\underline{a}}$ (região norte)

Miguel Mussi, Prof (região norte)

Narciso Nicolodi, Ir. (região norte)

Neide Apparecida Golfetto de Castro (região leste)

Nicolau Dinamarco Spinelli, Dr. (região leste)

Paulo Henrique de Souza (região norte)

Quintino Vieira (região oeste)

Roberto Afonso Pontes (região oeste)

Ruy Escorel Ferreira Santos (região norte)

Santa Terezinha (região oeste)

Teresa Hendrica Antonissen (Miss Margareth) (região norte)

Wanda Princivalli Marçal (região leste)

Zilda Cossa D'ávila (região sul)

Wilson Roselino, Dro (região leste) 
- 2 Centros de Educação Infantil - CEls (crianças de 4 e 5 anos)

Deolinda Gasparini - Unidade II (região oeste)

Roberto Taranto, $\mathrm{Dr}$ (região norte)

- 25 Escolas Municipais de Ensino Fundamental - EMEFs (crianças de 1ํㅜ a $5^{\circ}$ ano)

Alcina dos Santos Heck (região leste)

Anísio Teixeira, Prof. (região norte)

Antonio Palocci - CAIC (região norte)

Dercy Célia Seixas Ferrari. Prof. ${ }^{\text {a }}$ (região leste)

Domingos Angerami, Prof. (região norte)

Elisa Duboc Garcia, Profáa (região leste)

Eponina de Britto Rossetto, Prof. . (região leste)

Faustino Jarruche, Dr. (região oeste)

Geralda de Sousa Espin (região norte)

Honorato de Lucca, Prof. (região oeste)

Jaime Monteiro de Barros, Dr. (região norte)

Jarbas Massullo, Prof. (região norte)

José Delibo, Vereador (região norte)

José Rodini Luiz, Prof. (região norte)

Júlio César Voltarelli (região leste)

Maria Ignez Lopes Rossi, Prof. ${ }^{a}$ (região oeste)

Maria Ines Vieira Machado (região norte)

Nelson Machado (região norte)

Neuza Michelutti Marzola, Prof. ${ }^{\text {a }}$ (região leste)

Paulo Freire, Prof. (região leste)

Paulo Monte Serrat Filho, Prof. Dr. (região leste)

Raul Machado, Prof. (região leste)

Salvador Marturano, Prof. (região norte)

Sebastião de Aguiar Azevedo (região norte)

Waldemar Roberto Prof. Dr. (região leste)

- 3 Centros Municipais de Educação Integrada - CEMEls ( crianças de $1^{\circ}$ ao $5^{\circ}$ ano)

Eduardo Romualdo de Souza, Prof. (região leste)

João Gilberto Sampaio, Dr. (região norte)

Virgílio Salata. (região oeste)

- 2 Escolas Municipais de Ensino Fundamental e Médio - EMEFEMs (crianças de $1^{\circ}$ a $5^{\circ}$ ano)

Alfeu Luiz Gasparini, Prof. (região norte)

Luiz do Amaral Mousinho, Dom (região oeste)

- 1 Centro de Educação Especial e Ensino Fundamental - CEEEF (1ํa a $\left.5^{\circ}\right)$

Egydio Pedreschi (região leste) 
Apêndice B - Tabela completa dos capítulos Cid-10, categorias das doenças, números de casos, dias de faltas e porcentagens

\begin{tabular}{|c|c|c|c|}
\hline Capítulos da CID-10 & $\begin{array}{c}\text { Tipos de Doença (Categoria } \\
\text { da CID-10) }\end{array}$ & $\begin{array}{l}\text { Número } \\
\text { de } \\
\text { Casos } \\
\text { Doença }\end{array}$ & $\begin{array}{l}\text { Porcenta- } \\
\text { gem de } \\
\text { casos } \\
\text { Doença }\end{array}$ \\
\hline \multicolumn{4}{|l|}{ Algumas doenças } \\
\hline infecciosas e & Doenças infecciosas & & \\
\hline $\begin{array}{l}\text { parasitárias } \\
\text { Algumas doenças }\end{array}$ & intestinais & 80 & $4,0 \%$ \\
\hline infecciosas e & Febres por arbovírus e febres & & \\
\hline $\begin{array}{l}\text { parasitárias } \\
\text { Algumas doenças }\end{array}$ & hemorrágicas virais & 12 & $0,6 \%$ \\
\hline infecciosas e & Infecções de transmissão & & \\
\hline $\begin{array}{l}\text { parasitárias } \\
\text { Algumas doenças }\end{array}$ & predominantemente sexual & 1 & $0,1 \%$ \\
\hline $\begin{array}{l}\text { infecciosas e } \\
\text { parasitárias }\end{array}$ & Infecções virais caracterizadas & 2 & $0.1 \%$ \\
\hline $\begin{array}{l}\text { Algumas doenças } \\
\text { infecciosas e }\end{array}$ & & & 0 \\
\hline parasitárias & Micoses & 3 & $0,2 \%$ \\
\hline $\begin{array}{l}\text { Algumas doenças } \\
\text { infecciosas e }\end{array}$ & & & \\
\hline parasitárias & Outras doenças por vírus & 4 & $0,2 \%$ \\
\hline tecido subcutâneo & Afecções dos anexos da pele & 9 & $0,5 \%$ \\
\hline $\begin{array}{l}\text { Doenças da pele e do } \\
\text { tecido subcutâneo }\end{array}$ & Dermatite e eczema & 4 & $0,2 \%$ \\
\hline Doenças da pele e do & Infecções da pele e do tecido & & \\
\hline tecido subcutâneo & subcutâneo & 6 & $0,3 \%$ \\
\hline $\begin{array}{l}\text { Doenças da pele e do } \\
\text { tecido subcutâneo }\end{array}$ & $\begin{array}{l}\text { Outras afecções da pele e do } \\
\text { tecido subcutâneo }\end{array}$ & 4 & $0,2 \%$ \\
\hline Doenças da pele e do & $\begin{array}{l}\text { Transtornos da pele e do } \\
\text { tecido subcutâneo }\end{array}$ & & \\
\hline $\begin{array}{l}\text { tecido subcutâneo } \\
\text { Doenças da pele e do }\end{array}$ & relacionados com a radiação & 1 & $0,1 \%$ \\
\hline $\begin{array}{l}\text { tecido subcutâneo } \\
\text { Doenças do aparelho }\end{array}$ & Urticária e eritema & 6 & $0,3 \%$ \\
\hline circulatório & $\begin{array}{l}\text { Doenças cerebrovasculares } \\
\text { Doenças das veias, dos vasos } \\
\text { linfáticos e dos gânglios }\end{array}$ & 10 & $0,5 \%$ \\
\hline $\begin{array}{l}\text { Doenças do aparelho } \\
\text { circulatório } \\
\text { Doenças do aparelho }\end{array}$ & $\begin{array}{l}\text { linfáticos, não classificadas em } \\
\text { outra parte }\end{array}$ & 23 & $1,2 \%$ \\
\hline circulatório & Doenças hipertensivas & 33 & $1,7 \%$ \\
\hline $\begin{array}{l}\text { Doenças do aparelho } \\
\text { circulatório }\end{array}$ & $\begin{array}{l}\text { Doenças isquêmicas do } \\
\text { coração }\end{array}$ & 2 & $0,1 \%$ \\
\hline $\begin{array}{l}\text { Doenças do aparelho } \\
\text { circulatório }\end{array}$ & $\begin{array}{l}\text { Outras formas de doença do } \\
\text { coração } \\
\text { Doenças da cavidade oral, das }\end{array}$ & 1 & $0,1 \%$ \\
\hline $\begin{array}{l}\text { Doenças do aparelho } \\
\text { digestivo } \\
\text { Doenças do aparelho }\end{array}$ & $\begin{array}{l}\text { glândulas salivares e dos } \\
\text { maxilares }\end{array}$ & 62 & $3,1 \%$ \\
\hline digestivo & Doenças do apêndice & 1 & $0,1 \%$ \\
\hline $\begin{array}{l}\text { Doenças do aparelho } \\
\text { digestivo }\end{array}$ & $\begin{array}{l}\text { Doenças do esôfago, do } \\
\text { estômago e do duodeno }\end{array}$ & 27 & $1,4 \%$ \\
\hline $\begin{array}{l}\text { Doenças do aparelho } \\
\text { digestivo } \\
\text { Doenças do aparelho }\end{array}$ & $\begin{array}{l}\text { Enterites e colites não- } \\
\text { infecciosas }\end{array}$ & 27 & $1,4 \%$ \\
\hline digestivo & Hérnias & 6 & $\begin{array}{c}0,3 \% \\
\text { Continua }\end{array}$ \\
\hline
\end{tabular}




\begin{tabular}{|c|c|c|c|}
\hline Capítulos da CID-10 & $\begin{array}{c}\text { Tipos de Doença (Categoria } \\
\text { da CID-10) }\end{array}$ & $\begin{array}{c}\text { Número } \\
\text { de } \\
\text { Casos } \\
\text { Doença }\end{array}$ & $\begin{array}{c}\text { Porcenta- } \\
\text { gem de } \\
\text { casos } \\
\text { Doença }\end{array}$ \\
\hline $\begin{array}{l}\text { Doenças do aparelho } \\
\text { digestivo }\end{array}$ & Outras doencas dos intestinos & 25 & $0.4 \%$ \\
\hline $\begin{array}{l}\text { Doenças do aparelho } \\
\text { diaestivo }\end{array}$ & Transtornos da vesícula biliar, & & \\
\hline $\begin{array}{l}\text { digestivo } \\
\text { Doenças do aparelho }\end{array}$ & das vias biliares e do pâncreas & 7 & $0,4 \%$ \\
\hline geniturinário & Calculose renal & 17 & $0,9 \%$ \\
\hline geniturinário & Doenças da mama & 4 & $0,2 \%$ \\
\hline geniturinário & Doenças glomerulares & 1 & $0,1 \%$ \\
\hline $\begin{array}{l}\text { Doenças do aparelho } \\
\text { geniturinário }\end{array}$ & $\begin{array}{l}\text { Doenças inflamatórias dos } \\
\text { órgãos pélvicos femininos }\end{array}$ & 6 & $0,3 \%$ \\
\hline $\begin{array}{l}\text { Doenças do aparelho } \\
\text { geniturinário }\end{array}$ & $\begin{array}{l}\text { Doenças renais túbulo- } \\
\text { intersticiais }\end{array}$ & 2 & $0,1 \%$ \\
\hline $\begin{array}{l}\text { Doenças do aparelho } \\
\text { geniturinário }\end{array}$ & $\begin{array}{l}\text { Outras doenças do aparelho } \\
\text { urinário }\end{array}$ & 37 & $1,9 \%$ \\
\hline $\begin{array}{l}\text { Doenças do aparelho } \\
\text { geniturinário }\end{array}$ & $\begin{array}{l}\text { Outros transtornos do rim e do } \\
\text { ureter }\end{array}$ & 1 & $0,1 \%$ \\
\hline $\begin{array}{l}\text { Doenças do aparelho } \\
\text { geniturinário }\end{array}$ & $\begin{array}{l}\text { Transtornos não-inflamatórios } \\
\text { do trato genital feminino }\end{array}$ & 27 & $1,4 \%$ \\
\hline $\begin{array}{l}\text { Doenças do aparelho } \\
\text { respiratório }\end{array}$ & $\begin{array}{l}\text { Doenças crônicas das vias } \\
\text { aéreas inferiores }\end{array}$ & 16 & $0,8 \%$ \\
\hline $\begin{array}{l}\text { Doenças do aparelho } \\
\text { respiratório } \\
\text { Doencas do aparelho }\end{array}$ & $\begin{array}{l}\text { Infecções agudas das vias } \\
\text { aéreas superiores }\end{array}$ & 149 & $7,5 \%$ \\
\hline $\begin{array}{l}\text { Doenças do aparelho } \\
\text { respiratório } \\
\text { Doenças do aparelho }\end{array}$ & Influenza [gripe] e pneumonia & 28 & $1,4 \%$ \\
\hline respiratório & Outras doenças da pleura & 1 & $0,1 \%$ \\
\hline $\begin{array}{l}\text { Doenças do aparelho } \\
\text { respiratório }\end{array}$ & $\begin{array}{l}\text { Outras doenças das vias } \\
\text { aéreas superiores }\end{array}$ & 34 & $1,7 \%$ \\
\hline $\begin{array}{l}\text { Doenças do aparelho } \\
\text { respiratório }\end{array}$ & $\begin{array}{l}\text { Outras doenças do aparelho } \\
\text { respiratório }\end{array}$ & 1 & $0,1 \%$ \\
\hline $\begin{array}{l}\text { Doenças do aparelho } \\
\text { respiratório }\end{array}$ & $\begin{array}{l}\text { Outras infecções agudas das } \\
\text { vias aéreas inferiores }\end{array}$ & 1 & $0,1 \%$ \\
\hline $\begin{array}{l}\text { Doenças do olho e } \\
\text { anexos }\end{array}$ & $\begin{array}{l}\text { Outros transtornos do olho e } \\
\text { anexos }\end{array}$ & 1 & $0,1 \%$ \\
\hline $\begin{array}{l}\text { Doenças do olho e } \\
\text { anexos }\end{array}$ & Transtornos da conjuntiva & 36 & $1,8 \%$ \\
\hline $\begin{array}{l}\text { Doenças do olho e } \\
\text { anexos }\end{array}$ & $\begin{array}{l}\text { Transtornos da coróide e da } \\
\text { retina }\end{array}$ & 4 & $0,2 \%$ \\
\hline $\begin{array}{l}\text { Doenças do olho e } \\
\text { anexos } \\
\text { Doencas do olho e }\end{array}$ & $\begin{array}{l}\text { Transtornos da esclerótica, da } \\
\text { córnea, da íris e do corpo ciliar }\end{array}$ & 4 & $0,2 \%$ \\
\hline $\begin{array}{l}\text { Doenças do olho e } \\
\text { anexos }\end{array}$ & $\begin{array}{l}\text { Transtornos da pálpebra, do } \\
\text { aparelho lacrimal e da órbita }\end{array}$ & 5 & $0,3 \%$ \\
\hline $\begin{array}{l}\text { Doenças do olho e } \\
\text { anexos }\end{array}$ & $\begin{array}{l}\text { Transtornos do cristalino } \\
\text { Transtornos dos músculos } \\
\text { oculares, do movimento }\end{array}$ & 7 & $0,4 \%$ \\
\hline $\begin{array}{l}\text { Doenças do olho e } \\
\text { anexos } \\
\text { Doencas do ouvido e da }\end{array}$ & $\begin{array}{l}\text { binocular, da acomodação e } \\
\text { da refração }\end{array}$ & 17 & $0,9 \%$ \\
\hline apófise mastoide & Doenças do ouvido interno & 27 & $1,4 \%$ \\
\hline $\begin{array}{l}\text { Doenças do ouvido e da } \\
\text { apófise mastoide } \\
\text { Doenças do ouvido e da }\end{array}$ & $\begin{array}{l}\text { Doenças do ouvido médio e } \\
\text { da mastóide }\end{array}$ & 7 & $0,4 \%$ \\
\hline apófise mastoide & Outros transtornos do ouvido & 3 & $0,2 \%$ \\
\hline $\begin{array}{l}\text { Doenças do sistema } \\
\text { nervoso }\end{array}$ & $\begin{array}{l}\text { Transtornos dos nervos, das } \\
\text { raízes e dos plexos nervosos }\end{array}$ & 4 & $\begin{array}{c}0,2 \% \\
\text { Continu }\end{array}$ \\
\hline
\end{tabular}




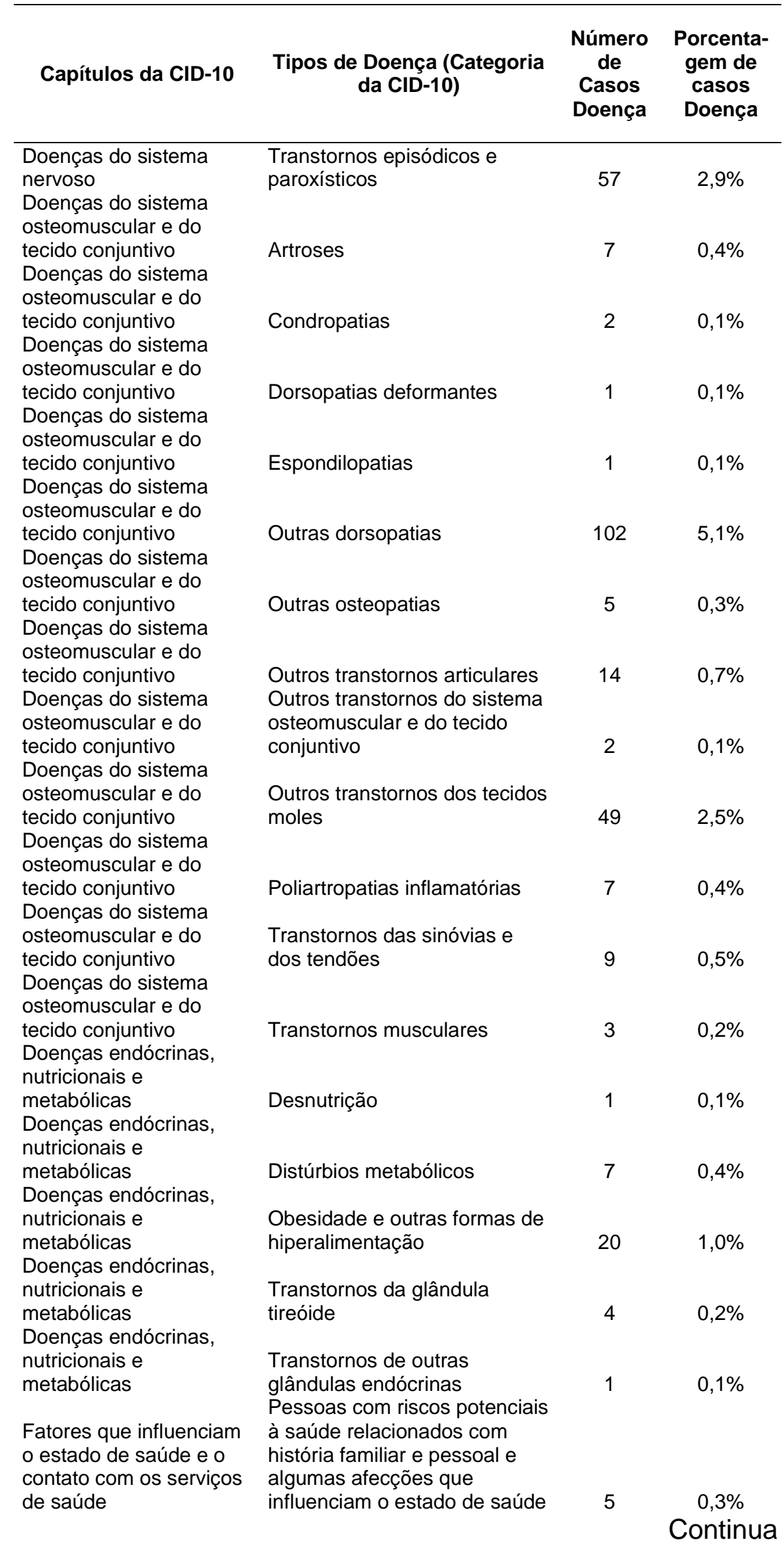




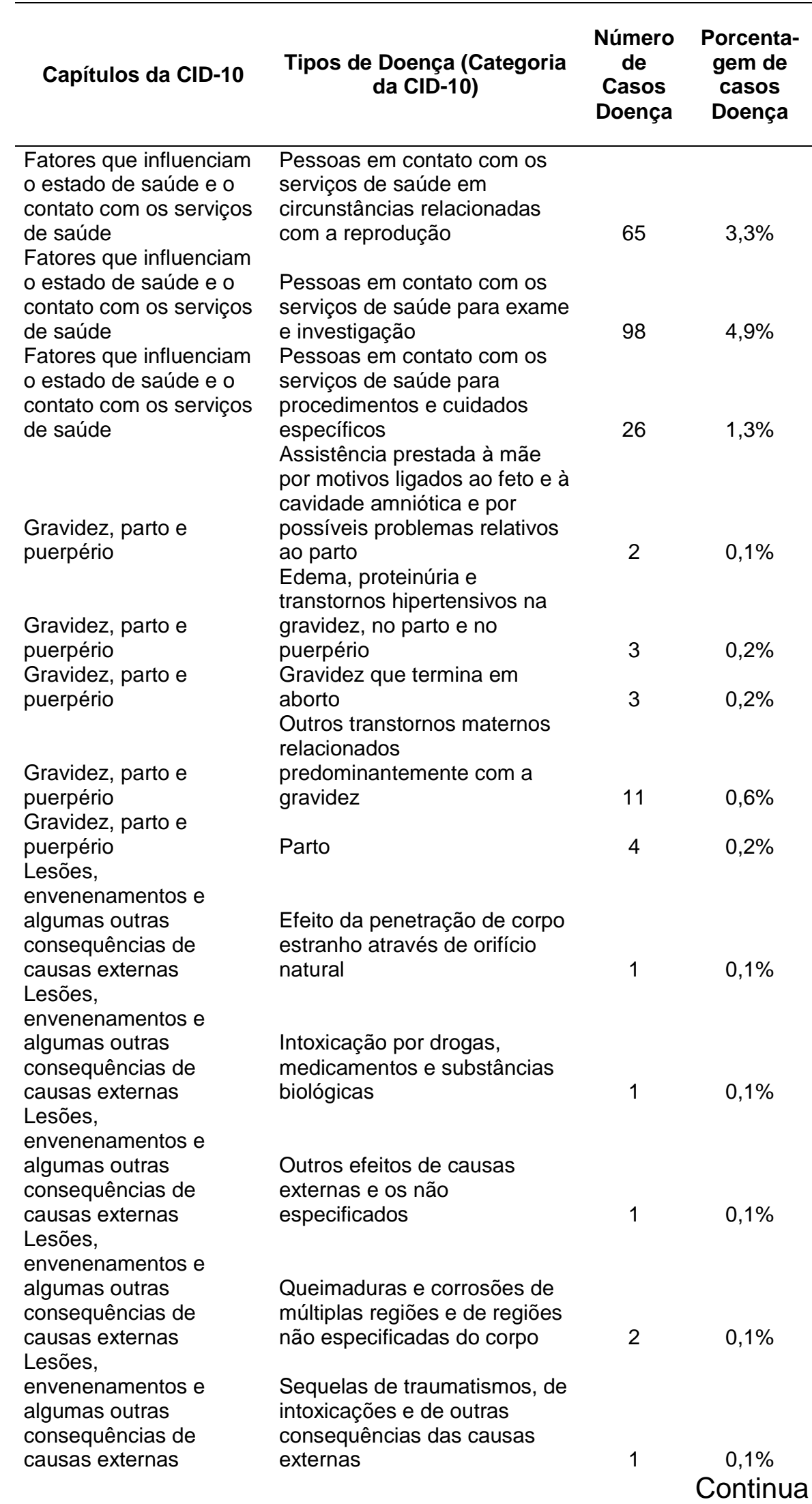


Continuação

\section{Capítulos da CID-10}

Lesões,

envenenamentos e

algumas outras

consequências de

causas externas

Lesões,

envenenamentos e

algumas outras

consequências de

causas externas

Lesões,

envenenamentos e

algumas outras

consequências de

causas externas

Lesões,

envenenamentos e

algumas outras consequências de

causas externas

Lesões,

envenenamentos e

algumas outras

consequências de

causas externas

Lesões,

envenenamentos $e$

algumas outras

consequências de

causas externas

Lesões,

envenenamentos e

algumas outras

consequências de

causas externas

Lesões,

envenenamentos e

algumas outras

consequências de

causas externas

Lesões,

envenenamentos e

algumas outras

consequências de

causas externas

Lesões,

envenenamentos e

algumas outras

consequências de

causas externas

Malformações

congênitas,

deformidades e

anomalias

cromossômicas

Neoplasmas (tumores)
Tipos de Doença (Categoria da CID-10)

\section{Número Porcenta- \\ de \\ gem de \\ Casos \\ casos \\ Doença Doença}

Traumatismos da cabeça

5

$0,3 \%$

Traumatismos de localização não especificada do tronco, membro ou outra região do corpo

4

$0,2 \%$

Traumatismos do abdome, do dorso, da coluna lombar e da pelve

$2 \quad 0,1 \%$

Traumatismos do cotovelo e do antebraço

$5 \quad 0,3 \%$

Traumatismos do joelho e da perna

Traumatismos do ombro e do braço

Traumatismos do punho e da mão

$0,3 \%$

Traumatismos do tornozelo e do pé

$31 \quad 1,6 \%$

Traumatismos do tórax

2

$0,1 \%$

Traumatismos envolvendo múltiplas regiões do corpo

$4 \quad 0,2 \%$

Malformações congênitas do aparelho circulatório Melanoma e outras(os) neoplasias malignas da pele
$3 \quad 0,2 \%$

$0,1 \%$ 
Continuação

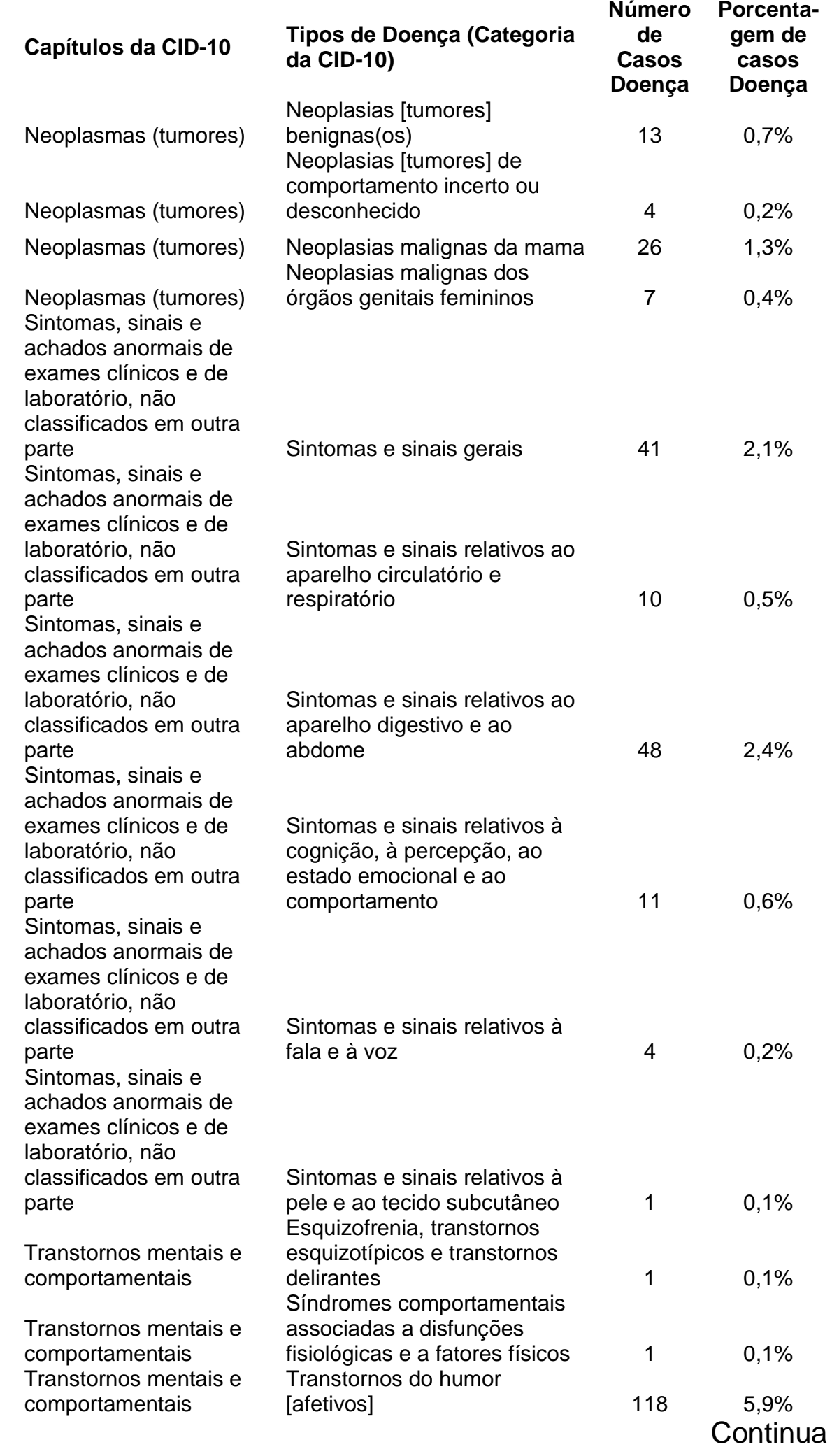


Conclusão

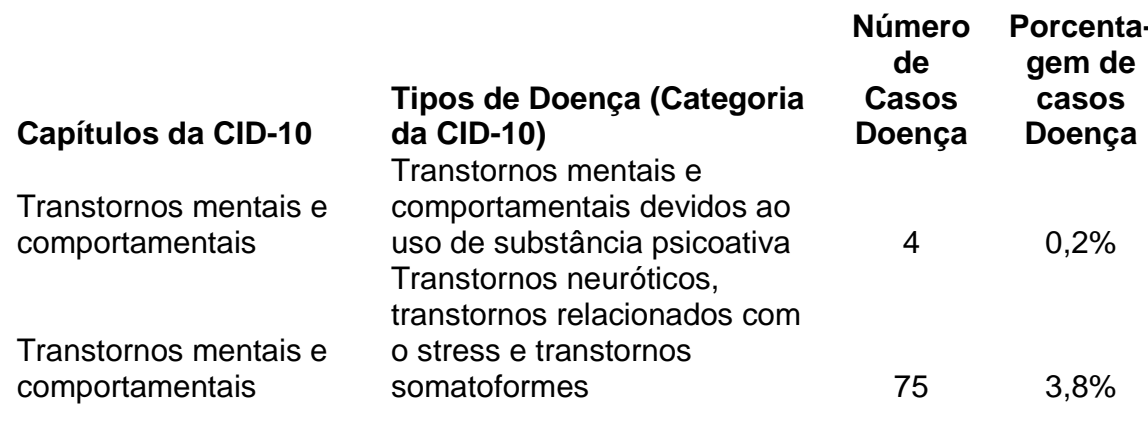

Fonte: Elaborado pelo autor com base nos dados Ribeirão Preto, 2015. 


\section{Anexo A - Documento de aprovação perante o Comitê de Ética em Pesquisado HCRP e da FMRP-USP}

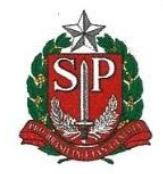

HOSPITAL DAS CLÍNICAS DA FACULDADE DE MEDICINA DE RIBEIRÃO PRETO DA UNIVERSIDADE DE SÃO PAULO
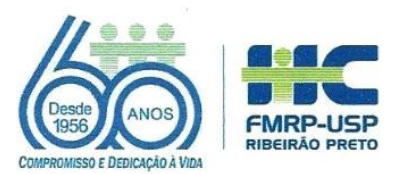

Ribeirão Preto, 23 de novembro de 2016.

Oficio $\mathrm{n}^{\circ} 3925 / 2016$

CEP/MGV

PROCESSO HCRP n $\mathrm{n}^{\circ} 14621 / 2016$

Prezados Pesquisadores,

O trabalho intitulado "ANÁLISE DO ABSENTEÍSMO POR DOENÇAS EM DOCENTES DO ENSINO FUNDAMENTAL", foi analisado pelo Comitê de Ética em Pesquisa, em sua $441^{a}$ Reunião Ordinária realizada em $21 / 11 / 2016$, e enquadrado na categoria: APROVADO, bem como a solicitação de dispensa de aplicação do Termo de Consentimento Livre e Esclarecido.

De acordo com Carta Circular no 003/2011/CONEP/CNS, datada de 21/03/2011, o sujeito de pesquisa ou seu representante, quando for o caso, deverá rubricar todas as folhas do Termo de Consentimento Livre e Esclarecido - TCLE - apondo sua assinatura na última do referido Termo; o pesquisador responsável deverá da mesma forma, rubricar todas as folhas do Termo de Consentimento Livre e Esclarecido - TCLE-apondo sua assinatura na última página do referido Termo.

Este Comitê segue integralmente a Conferência Internacional de Harmonização de Boas Práticas Clínicas (IGH-GCP), bem como a Resolução $n^{\circ}$ 466/2012 CNS/MS.

Lembramos que devem ser apresentados a este CEP, o Relatório Parcial e o Relatório Final da pesquisa. Atenciosamente.

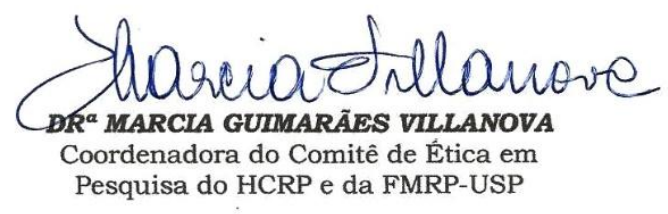

Ilustrissimos Senhores

RAQUEL AMÉLIA COSTA

DR. AMAURY P. GREMAUD (Orientador)

Mestrado Profissional em Gestão de Organizações de Saúde

\footnotetext{
HOSPITAL DAS CLINICAS DA FACULDADE DE MEDICINA DE RIBEIRÃO PRETO DA UNIVERSIDADE DE SÄO PAULO $\begin{array}{lll}\text { Campus Universitário - Monte Alegre } & \text { Comitê de Ética em Pesquisa do HCRP e FMRP-USP } \\ 14048-900 & \text { Ribeirăo Preto SP } & \text { FWA-00002733; IRB-00002186 }\end{array}$ $\begin{array}{lll}14048-900 & \text { Ribeirão Preto SP } & \text { FWA-00002733; IRB-00002186 } \\ \text { Registro Plataforma Brasil /CONEP } \mathrm{n}^{\circ} 5440\end{array}$ (016) 3602-2228
} 
Anexo B - Termo de consentimento livre e esclarecido"

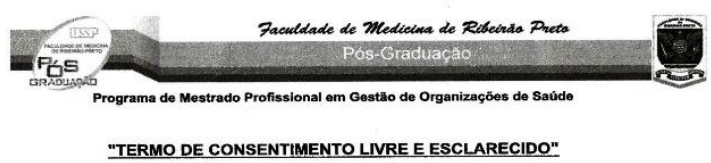

IImo. Sr. Thomaz Perianhes Junior

Secretaria Municipal de Administraçăo de Ribeirão Preto

Secretaria Municipal de Educaçăo de Ribeirão Preto

Eu, Raquel Amélia Costa, aluna do Mestrado Profissional em

Gestăo de Organizaçōes de Saúde da Faculdade de Medicina de Ribeirăo Preto FMRP/USP, orientada pelo Prof. Dr. Amaury Gremaud, venho solicitar a V. Sa. autorizaçăo para coletar os dados presentes nos atestados médicos dos professores de PB II, com a finalidade de realizar pesquisa para a dissertaçăo de Mestrado, intitulada "Análise do absenteismo por doenças em docentes do ensino fundamental", cujo objetivo é analisar as causas do absenteísmo por doença de docentes no ensino fundamental em instituiçöes públicas de ensino.

Os dados serăo coletados dos atestados médicos e fichas dos professores para mapear tipo de doença (CID), sexo, idade, reincidência da doença, reglão de trabalho do docente.

Ressalto que estou ciente de que serăo garantidos os direitos, dentre outros assegurados pela resoluçăo 196/96 do Conselho Nacional de Saúde, de:

1) Garantia da confidencialidade, do anonimato e da năo utillzaçăo das informaçôes em prejuizo dos pacientes e dos demais envolvidos.

2) Que não haverá riscos para o sujeito de pesquisa.

3) Emprego dos dados somente para fins previstos nesta pesquisa.

Informo-lhe alnda, que a pesquisa somente será iniciada após a aprovacăo da Comitê de Ética em Pesquisa. (Para quaisquer informaçăo. o Comite de Ética em Pesquisa disponibiliza o telefone: 016-3602-2228)

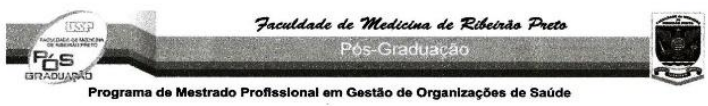

Comprometo-me a disponibilizar os dados resultantes da pesquisa, juntamente com o Trabalho de Conclusão de Curso, a esta instituiçăo.

Agradeço a atençăo dispensada $\Theta$ disponibilizo-me para quaisquer esclarecimento.

Atenciosamente, Dst

Raquel Amélia Costa

(16) 981159757

Eu, Amaury Gremaud, responsabilizo-me pelo trabalho cientifico da aluna Raquel Amélia Costa.
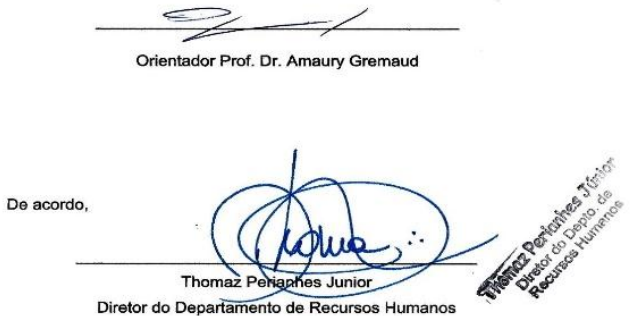

Diretor do Departamento de Recursos Humanos

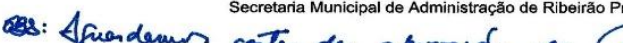

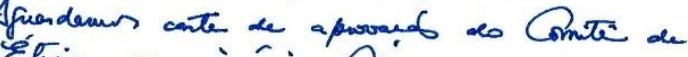
Étien pora inewi. 